Vítor Augusto Andreghetto Bortolin

Investigação das causas das instabilidades na Oxi-combustão de Gás Natural por Quimioluminescência

São Paulo

2019 

Vítor Augusto Andreghetto Bortolin

\title{
Investigação das causas das instabilidades na Oxi-combustão de Gás Natural por Quimioluminescência
}

\author{
Dissertação apresentada a Escola Politéc- \\ nica da Universidade de São Paulo para \\ obtenção do título de Mestre em Ciências. \\ Área de concentração: Engenharia me- \\ cânica, energia e fluídos \\ Orientador: Guenther Carlos Krieger Fi- \\ Iho \\ Universidade de São Paulo - USP \\ Escola Politécnica
}

São Paulo

2019 

Autorizo a reprodução e divulgação total ou parcial deste trabalho, por qualquer meio convencional ou eletrônico, para fins de estudo e pesquisa, desde que citada a fonte.

\section{Catalogação-na-publicação}

Bortolin, Vítor Augusto Andreghetto Investigação das causas das instabilidades na Oxi-combustão de Gás Natural por Quimioluminescência / V. A. A. Bortolin -- São Paulo, 2019. $60 \mathrm{p}$.

Dissertação (Mestrado) - Escola Politécnica da Universidade de São Paulo. Departamento de Engenharia Mecânica.

1.Engenharia Mecânica 2.Combustão 3.Gás natural 4.Captura de carbono I.Universidade de São Paulo. Escola Politécnica. Departamento de Engenharia Mecânica II.t. 


\section{Sumário}

$1 \quad$ INTRODUÇÃO $\ldots \ldots \ldots \ldots \ldots \ldots \ldots \ldots \ldots \ldots$

$1.1 \quad$ Formulação do problema $\ldots \ldots \ldots \ldots \ldots \ldots$

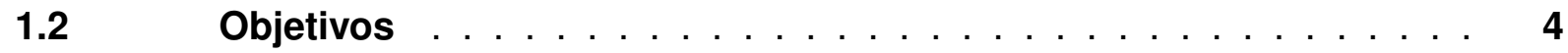

$1.3 \quad$ Estrutura do trabalho $\ldots \ldots \ldots \ldots \ldots \ldots \ldots$

$2 \quad$ REVISÃO BIBLIOGRÁFICA $\ldots \ldots \ldots \ldots \ldots \ldots \ldots$

$2.1 \quad$ Estado da arte da Tecnologia $\ldots \ldots \ldots \ldots \ldots$

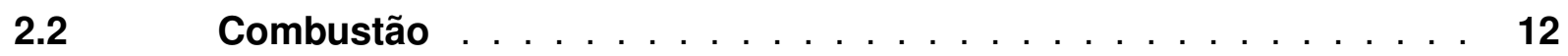

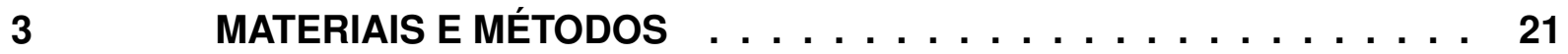

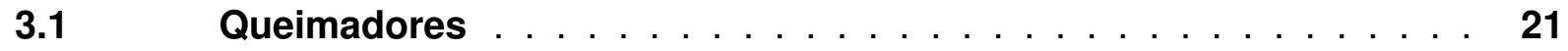

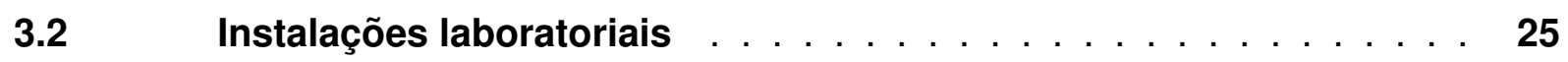

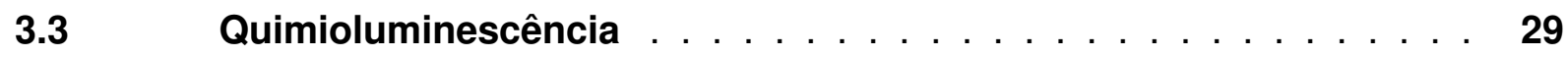

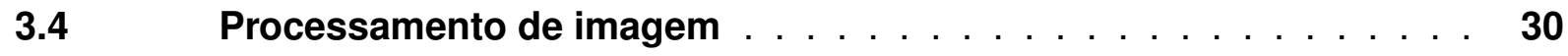

$3.5 \quad$ Anemômetro de fio quente $\ldots \ldots \ldots \ldots \ldots \ldots$

$3.6 \quad$ Incertezas $\ldots \ldots \ldots \ldots \ldots \ldots$

$4 \quad$ RESULTADOS . . . . . . . . . . . . . . . . . . . . . . . . 39

$4.1 \quad$ Queimador Yale . . . . . . . . . . . . . . . . . . . . . . 39

$4.2 \quad$ Velocidade de chama laminar . . . . . . . . . . . . . . 44

$4.3 \quad$ Queimador Cabra . . . . . . . . . . . . . . . . . . . . . . . 47

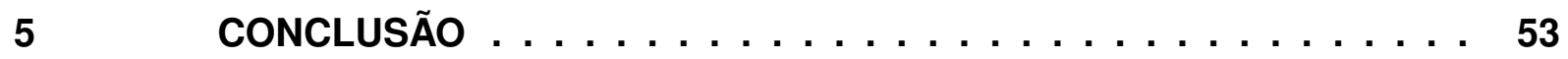

$5.1 \quad$ Trabalhos Futuros $\ldots \ldots \ldots \ldots \ldots \ldots \ldots$

$6 \quad$ PUBLICAÇÕES $\ldots \ldots \ldots \ldots \ldots \ldots \ldots \ldots$

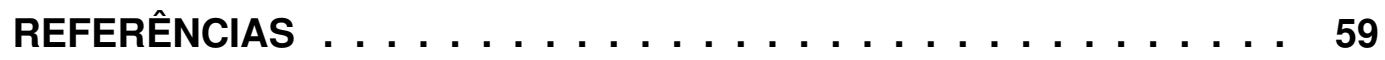




\section{Lista de ilustrações}

Figura 1 - Esquema de uma usina termoelétrica convencional . . . . . . . . . . . . 3

Figura 2 - Esquema de uma usina com CAC e oxi-combustão . . . . . . . . . . . . 4

Figura 3 - Comparação da eficiência energética entre o ciclo tradicional e as técnicas de CAC . . . . . . . . . . . . . . . . . . . . . . 10

Figura 4 - Queimador de $170 M W$. . . . . . . . . . . . . . . . . . . . . 10

Figura 5 - Comparação entre um ciclo tradicional a carvão com oxi-combustão e um com gaseificação e ciclo combinado . . . . . . . . . . . . . . . . . 11

Figura 6 - Simulação da cinética química de oxi-combustão para oxidantes com diferentes concentrações de dióxido de carbono . . . . . . . . . . . . 15

Figura 7 - Chama suspensa . . . . . . . . . . . . . . . . . . . 17

Figura 8 - Quimioluminescência de uma chama tripla . . . . . . . . . . . . . . . 18

Figura 9 - Chama de difusão envolta em um Coflow de chamas pilotos . . . . . . . 19

Figura 10 - Projeto do queimador . . . . . . . . . . . . . . . . . . 22

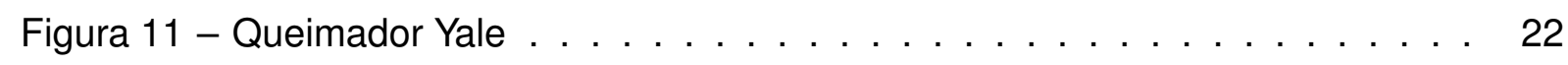

Figura 12 - llustração da chama cônica . . . . . . . . . . . . . . . . . . . . 23

Figura 13 - Queimador de chama cônica . . . . . . . . . . . . . . . . . . . . . 24

Figura 14 - Imagens do queimador cabra . . . . . . . . . . . . . . . . . . . . 25

Figura 15 - Distribuição de gás na parede interior do laboratório . . . . . . . . . . . 26

Figura 16 - Subsistema de segurança . . . . . . . . . . . . . . . . . . . . . 27

Figura 17 - Subsistema de segurança . . . . . . . . . . . . . . . . . . 27

Figura 18 -rotametros . . . . . . . . . . . . . . . . . . . . 28

Figura 19 - camera . . . . . . . . . . . . . . . . . . . . . . 28

Figura 20 - Bancada experimental com dois queimadores posicionados . . . . . . . 29

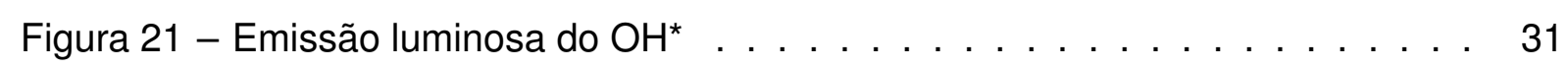

Figura 22 - Imagens para o procedimento de correção das distorções do conjunto

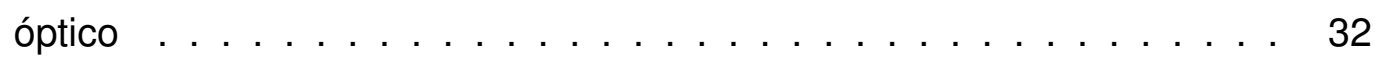

Figura 23 - Exemplo da transformada de Hough . . . . . . . . . . . . . . . . 33

Figura 24 - Chama cônica com as linhas obtidas pelo transformada de Hough . . . 34

Figura 25 - Imagem da sonda utilizada . . . . . . . . . . . . . . . . . . . 34

Figura 26 - Aparato experimental utilizado . . . . . . . . . . . . . . . . . . . 35

Figura 27 - velocidade média ao longo do raio nos dois experimentos realizados . . 36

Figura 28 - intensidade turbulenta no queimador . . . . . . . . . . . . . . . . 37

Figura 29 - Testes com chama no queimador Yale . . . . . . . . . . . . . . . . . 40

Figura 30 -Imagens do calibrador . . . . . . . . . . . . . . . . . . . 41

Figura 31 - Chama de referência no ar . . . . . . . . . . . . . . . . . 42 
Figura 32 - Chamas de metano em atmosferas controladas com fração molar de oxigênio de 50\%, 40\% e 35\% respectivamente . . . . . . . . . . 42

Figura 33 -Imagens de emissão de $\mathrm{OH}^{*} \ldots \ldots \ldots \ldots$. . . . . . . . . 43

Figura 34 - Chamas de difusão com as maiores diluições obtidas . . . . . . . . 44

Figura 35 - Combustão de metano no ar . . . . . . . . . . . . . . . . 45

Figura 36 - Oxi-combustão diluída com $\mathrm{CO}_{2}, \mathrm{~N}_{2}$ e $\mathrm{Ar} \ldots \ldots \ldots$

Figura 37 - Simulação com o mecanismo GRI3.0 de oxi-combustão com diferentes diluentes . . . . . . . . . . . . . . . . . . . . . . 48

Figura 38 - Teste em escoamento secundário quente . . . . . . . . . . . . . . 49

Figura 39 - Chama suspensa com ar e metano no tubo central . . . . . . . . . . . 50

Figura 40 - Chama suspensa com dióxido de carbono, oxigênio e metano no tubo

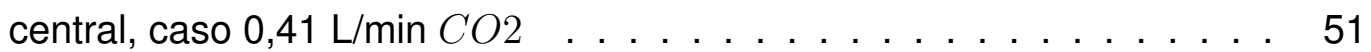

Figura 41 - Ensaios com chama suspensa com quantidades crescentes de $\mathrm{CO}_{2}$, casos $0,81 \mathrm{~L} / \mathrm{min}$ e $1,22 \mathrm{~L} / \min$ de $\mathrm{CO}_{2} \ldots \ldots \ldots \ldots \ldots$

Figura 42 - Ensaios com chama suspensa com quantidades crescentes de $\mathrm{CO}_{2}$, casos $1,62 \mathrm{~L} / \mathrm{min}$ e $2,03 \mathrm{~L} / \mathrm{min}$ de $\mathrm{CO}_{2} \ldots \ldots \ldots$. . . . . . . . . 52 


\section{Lista de tabelas}

Tabela 1 - Regimes para uma chama pré-misturada turbulenta . . . . . . . . . . . 13

Tabela 2 - Vazão de ar utilizada na anemometria . . . . . . . . . . . . . . . . . 35

Tabela 3 - vazões utilizadas no queimador Yale . . . . . . . . . . . . . . . . . 40

Tabela 4 - Composições do oxidante no queimador Yale . . . . . . . . . . . . . . . 41

Tabela 5 - Composições do escoamento no tubo central . . . . . . . . . . . . . . . 43

Tabela 6 - Temperaturas de chama adiabáticas para diluições com velocidade de chama laminar próximas . . . . . . . . . . . . . . . . . . . 47

Tabela 7 - Parâmetros experimentais utilizados . . . . . . . . . . . . . . . . . 49

Tabela 8 - Alturas das chamas em função da diluição da mistura combustível com

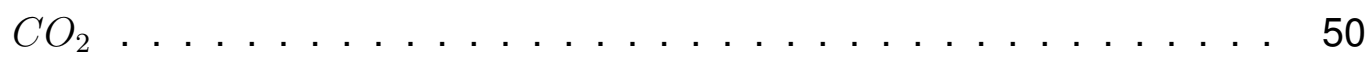





\section{Lista de símbolos}

$\begin{array}{ll}\alpha & \text { ângulo formado pelo cone da chama com a linha de centro } \\ S_{L} & \text { Velocidade de chama laminar } \\ u_{U} & \text { Velocidade média do escoamento } \\ K_{a} & \text { número de Karlovitz } \\ D_{a} & \text { número de Damköhler } \\ C_{p} & \text { Capacidade térmica à pressão constante } \\ O H * & \text { Radical hidroxila } \\ C H * & \text { Radical Methylidyne } \\ C O & \text { Monóxido de Carbono } \\ C O_{2} & \text { Dióxido de Carbono } \\ O_{2} & \text { Oxigênio } \\ A r & \text { Argônio } \\ N_{2} & \text { Nitrogênio }\end{array}$





\section{Agradecimentos}

Primeiramente agradeço a Deus pela oportunidade de conseguir realizar este trabalho na Universidade onde me formei. Agradeço a minha família pelo suporte emocional e financeiro, em especial, meus pais,minhas irmãs, meus avós maternos e meus padrinhos pela sua dedicação. Também agradeço especialmente a minha namorada, Lorena, que me apoiou nos momentos mais difíceis do meu trabalho, sem a sua ajuda não conseguiria realizar este trabalho. Também agradeço a todos os integrantes do laboratório LETE-CRC,(Claython, Rafael, Flávio, Fernando, Fillipi, José entre outros), que me ajudaram enormemente durante toda a pesquisa, sem essa ajuda, trabalho em equipe e espirito de união nenhum progresso seria realizado. Nesse caso, destaco a participação ativa dos meus colegas e amigos Bernardo e Rodrigo, que sem o seu suporte seria impossível realizar esta investigação experimental. Além disso, gostaria de agradecer a todos os funcionários da Universidade de São Paulo que contribuíram indiretamente para este estudo, como os técnicos: Erik, Douglas, Carlos, Cícero e Adilson, o pessoal da limpeza: Mari e Iracema, seguranças: Marcelino e Hélio, secretárias: Marisa, Regina e Ivana. Além de inúmeros integrantes do cotidiano da Universidade, infelizmente essa página é singela demais para conter todos nomes. Por fim, agradeço a todo o apoio concedido pelas agências de fomento CAPES, CNPQ e pela FAPESP. Agradeço ao apoio concedido pelo Fundação de Apoio a Universidade de São Paulo(FUSP), agradeço ao centro de pesquisa RCGl, e da ativa participação dos seus funcionário, Claudenor, Victor, Liu, Luís, Lúcia. Além do mais, agradeço à doação de material pela empresa OMINICORE, que sem essa doação seria impossível a realização de alguns experimentos. 

"All models are wrong, but some are useful."

(George Edward Pelham Box) 



\section{Resumo}

A oxi-combustão é uma tecnologia que se propõem auxiliar os processos de captura de carbono para que se tornem viáveis. Com ela é possível simplificar o processo de separação dos gases após a combustão. Isso ocorre, porque não há a presença do nitrogênio na reação oxidativa. Entretanto, essa abordagem exige que o oxigênio seja separado do ar antes da admissão na câmara de combustão, desse modo o comburente se torna um insumo caro que deve ser consumido na menor quantidade possível. Outro desafio são as altas temperaturas nesse processo de combustão, caso fosse admitido apenas o oxigênio no queimador as temperaturas ultrapassariam $3000 \mathrm{~K}$, de forma que nenhum material poderia suportar tais condições. Uma proposta para solucionar esse desafio, é diluir o processo com dióxido de carbono, reciclado da combustão anterior, assim sendo, reduziria-se a temperatura sem contaminar os produtos de combustão com algum gás inerte, o qual seria de difícil separação nas plantas de captura e armazenamento de carbono (CAC) . O problema com essa abordagem é que a presença do dióxido de carbono altera a reação reduzindo sua eficiência e estabilidade. Assim sendo, esse trabalho estudou as possíveis causas dessa mudança na oxi-combustão do gás natural diluída com dióxido de carbono. A literatura indica três hipóteses para essa mudança de comportamento: maior capacidade térmica a pressão constante do dióxido de carbono em relação ao nitrogênio; mudanças no coeficiente de difusão e interferência nas reação químicas devido a presença do $\mathrm{CO}_{2}$. $\mathrm{Na}$ primeira etapa do trabalho, foram feitas observações experimentais para avaliar quais seriam as mudanças em chamas de difusão. Esse estudo preliminar indicou que a maior capacidade térmica do dióxido de carbono parece não ser um fator determinante. Em seguida, foi medida a velocidade de chama laminar na oxi-combustão. Com esses experimentos e uma simulação numérica ficou evidente que as alterações no comportamento da chama são muito irregulares e não-lineares para serem causadas apenas pela maior capacidade térmica do dióxido de carbono. Além disso, o trabalho traz indícios de que grande parcela da mudança ocorre devido à interferência química do dióxido de carbono nas reações de combustão. Por fim, foi feito um estudo aplicado focado em chamas turbulentas suspensas, na qual a altura da chama se mostrou muito sensível à adição de dióxido de carbono no escoamento, o que novamente, indica uma sensibilidade maior do que a esperada pela capacidade térmica apenas.

Palavras-Chave: Oxi-combustão, gás natural, captura de carbono

\section{Abstract}

Oxy-combustion is a technology that is intended to make carbon capture processes viable, with it is possible to simplify the gas separation process after combustion. This occurs 
because the reaction occurs without the presence of nitrogen. However, this approach requires oxygen to be separated from the air before entering the combustion chamber, so the oxidizer becomes an expensive input that should be consumed in the smallest possible amount. Another challenge is the high temperatures in this type of combustion, if only the oxygen in the burner were admitted, no material could withstand such conditions. One proposal to solve this problem is to dilute the process with carbon dioxide, recycled from the previous combustion, thus reducing the temperature without contaminating the gases with some inert gas, which would be difficult to separate in the capture plants and storage (CCS). The problem with this approach is that the presence of carbon dioxide drastically alters combustion reducing its efficiency and stability. Thus, this work attempted to study the possible causes of this change in oxy-combustion of the natural gas diluted with carbon dioxide. The literature indicates three hypotheses for this behavior change: higher thermal capacity at constant pressure of carbon dioxide in relation to nitrogen, changes in diffusion coefficient and interference in chemical reactions due to the presence of $\mathrm{CO}_{2}$. In the first stage of the work, experimental observations were made to evaluate what the changes in diffusion flames would be. This preliminary study indicated that the increased thermal capacity of carbon dioxide does not appear to be a determining factor. As a second approuch, the velocity of laminar flame in oxy-combustion was measured. With these experiments and a numerical simulation it became evident that the changes in the behavior of the flame are very irregular and non-linear to be caused only by the greater thermal capacity of the carbon dioxide. In addition, the work suggests that much of the change occurs due to the chemical interference of carbon dioxide in the combustion reactions. Finally, a study was applied to suspended turbulent flames, in which the height of the flame was very sensitive to the addition of carbon dioxide in the flow, which again indicates a sensitivity greater than expected by the thermal capacity only.

Keywords:Oxy-fuel, natural gas, carbon capture 


\section{Introdução}

Desde o início do século XX, o consumo global de energia aumentou mais de dez vezes, movido principalmente pelo consumo dos combustíveis fósseis, o que elevou drasticamente as emissões de dióxido de carbono(KONTOROVICH; EPOV; EDER, 2014). Nesse período as emissões de dióxido de carbono, devidas aos combustíveis fósseis, passaram de uma gigatonelada de carbono, em 1920, para quase 10 gigatoneladas, em 2010, segundo Boden, Marland e Andres (2017). Esse volume de emissões corresponde a $65 \%$ do total de emissões antropogênicas de gases de efeito estufa(TEAM; PACHAURI; MEYER, 2014). Analisando-se os dados por setor econômico, a geração de eletricidade produz $25 \%$ do dióxido de carbono, enquanto o setor industrial é responsável por 21\% (TEAM; PACHAURI; MEYER, 2014). A origem das emissões nesses setores é o processo de combustão, em geral, continua em queimadores. Isso difere do setor de transportes, responsável por $14 \%$ do volume total de gases estufa produzidos(TEAM; PACHAURI; MEYER, 2014), no qual a combustão ocorre de forma intermitente nos motores. Assim, existem diferenças nas estratégias estudadas para reduzir as emissões em cada caso apesar de ambos originarem da oxidação de combustíveis fósseis.

No caso dos queimadores estacionários, presentes em caldeiras, turbinas e fornos, uma proposta para reduzir a liberação de gases estufa são as tecnologias de Captura e Armazenamento de Carbono (CAC). Essas tecnologias permitem o uso de fontes convencionais de energia, como o carvão e o gás natural, com drástica redução das emissões (ZHANG; LIOR, 2008). Em linhas gerais, as tecnologias de CAC consistem na captura, condicionamento e armazenagem dos produtos de combustão em galerias subterrâneas, poços de petróleo e minas abandonadas, entre outras localidades, impedindo que entrem na atmosfera e intensifiquem o aquecimento global. Uma vantagem dessa abordagem é que ela pode ser aplicada a plantas já existentes aproveitando a infraestrutura já criada o que permitiria uma transição rápida para uma economia de baixo carbono. Essas técnicas se encontram em fase semi-industrial com testes em termoelétricas e plantas de refino de gás natural (exemplos: The Boundary Dam project e The Sleipner CCS project). Além disso, já existem legislações para regulamentar sua utilização, por exemplo, a União Europeia incluiu a captura de carbono na EU Emissions Trading Directive (Directive 2009/29/EC) ,explicitamente no anexo I, permitindo que as plantas de CAC produzam créditos de carbono. Ademais, existem orientações de governos europeus para que futuras instalações elétricas sejam preparadas para acomodar futuras plantas de captura de carbono. Outra diretiva europeia(EU CCS Directive on Geological Storage of Carbon Dioxide (Directive 2009/31/EC)) regulamenta os projetos de CAC, focando, principalmente no armazenamento dos gases. Esse é um dos desafios dessas abordagens, pois os gases 
estufa devem ser acondicionados em estruturas geológicas por centenas de anos sem que escapem para a atmosfera ou prejudiquem o ecossistema. Outra dificuldade, são os altos custo associados a essas tecnologias, em especial, o custo operacional já que parte da energia será gasta continuamente na captura, transporte e acondicionamento dos produtos de combustão. Esse é um dos maiores impeditivos para a ampla utilização dessa tecnologia. Segundo Leung, Caramanna e Maroto-Valer (2014) de todas as etapas da CAC a captura representa a maior parcela dos custos, entre $70 \%-80 \%$ do total. Assim, há uma demanda por alternativas que simplifiquem e reduzam os custos dessa etapa.

Nesse contexto, outra abordagem para reduzir as emissões é a substituição de combustíveis, migrando de fontes ricas em carbono como o carvão mineral para fontes menos emissoras como o gás natural. Esse é composto majoritariamente de metano que é o hidrocarboneto com a maior quantidade de energia liberada por mol de dióxido de carbono produzido na combustão. Por isso, é visto como o combustível fóssil natural durante a transição energética das atuais fontes não-renováveis para as renováveis(HEKKERT et al., 2005). Para efeito de comparação, um megajoule vindo da combustão da gasolina produz cerca de $20 \%$ a mais de gases estufa em relação ao gás natural enquanto o carvão produz cerca de $40 \%$ a mais (BURNHAM et al., 2011). O uso do gás natural vem crescendo ininterruptamente nos últimos 20 anos e sua proporção na matriz energética global vem aumentando continuamente. Isto posto, espera-se que o gás natural se torne a maior fonte energética do mundo nos próximos anos(BIROL, 2017), assumindo o papel dominante na matriz energética, assim como o carvão dominou o século XIX e o petróleo o século XX. Porém, mesmo sendo o mais limpo dos combustíveis fósseis, não é isento de emissões, assim sendo a longo prazo não poderiam ser eliminadas as emissões de gases estufa apenas pela utilização do gás natural. Nessa perspectiva, pode-se associar o gás natural as tecnologias de CAC com intuito de eliminar suas emissões. Essa associação tem grande potencial, pois haveria um volume menor de gases a serem capturados, transportados e estocados em relação a qualquer outro combustível fóssil. Portanto, os custos relativos em uma planta de gás natural com um sistema de CAC seriam menores e a eficiência global da planta seria maior.

\subsection{Formulação do problema}

Comumente, as reações de combustão utilizam o ar como oxidante devido à sua disponibilidade, entretanto existem processos nos quais um oxidante artificialmente processado é utilizado como o oxigênio purificado. Nesse caso, essa tecnologia é chamada de oxi-combustão. Originalmente foi utilizada para obter altas temperaturas para processo de soldagem e em propulsores de foguete, mas hoje é vista como uma alternativa para viabilizar a captura de carbono. Como a oxi-combustão ocorre na ausência do nitrogênio, seus produtos de combustão são compostos apenas por vapor d'água e dióxido de car- 
bono. Isso possibilita separar o dióxido de carbono apenas condensando a água. Assim, se aplicada em uma planta com CAC, pode-se obter reduções de custos permitindo sua viabilidade comercial.

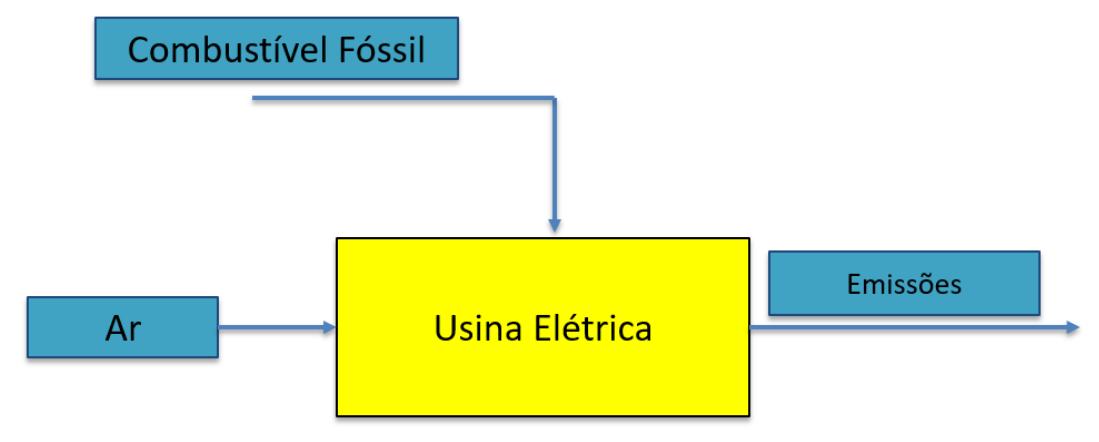

Figura 1 - Esquema de uma usina termoelétrica convencional

Comparando uma planta convencional (figura 1 com uma planta de oxi-combustão com CAC (figura 2), percebe-se a maior complexidade da instalação e a necessidade de uma planta de separação de ar. Entretanto, nessa abordagem o processo de separação dos gases de exaustão é simplificada e o volume de gases a ser estocado é minimizado, já que apenas dióxido de carbono será armazenado. Os estudos originais com oxi-combustão para aplicações no setor energético foram feitos para a combustão de carvão (SCHEFFKNECHT et al., 2011). Isso ocorreu porque a pressão ecológica sobre esse combustível fóssil é a maior e mais antiga, devido a grande quantidade de poluição produzida pela sua queima, e seu grande uso na geração de eletricidade.

No estudo de Wall, Stanger e Santos (2011), o estágio de desenvolvimento da tecnologia de oxi-combustão para plantas de carvão foi analisado e os autores concluíram que tal técnica já se encontra em estágio semi-comercial com plantas-piloto sendo testadas. Dentre os testes em escala industrial se destacam a termoelétrica a carvão Schwarze Pumpe Power Station na Alemanha e a Callide Power Station na Austrália, ambas movidas a carvão. Essas termoelétricas converteram parte de seu maquinário para operar em um ciclo de oxi-combustão com captura de carbono. No entanto, os projetos nestas duas plantas mostraram-se excessivamente caros o que levou ao encerramento das operações em ambas as plantas. A usina alemã operou de 2006 até 2014 com a planta de oxi-combustão, enquanto a australiana funcionou de 2015 até 2016.

Um dos grandes desafios nessa abordagem é reduzir as temperaturas da oxicombustão para valores adequados para serem utilizados em caldeiras e turbinas. Para tanto, o oxidante é diluída com dióxido de carbono, assim a temperatura dos produtos de reação é reduzida sem que os gases sejam contaminados por outros que atrapalhem o processo de separação. Outro ponto crucial é a economia de oxigênio, como este é um insumo caro, a planta deve consumir a menor quantidade possível, o que significa trabalhar 
o mais próximo possível da estequiometria. Contudo, nesse regime de combustão ocorrem reduções significativas na estabilidade da chama, há formação de fuligem, aumento da corrosão e alterações na transferência de calor(SCHEFFKNECHT et al., 2011: CHEN; YONG; GHONIEM, 2012; SUNDKVIST et al., 2014) que dificultam a operação na estequiometria.

A literatura descreve três principais hipóteses para essa variação: a maior capacidade térmica do dióxido de carbono, diferenças no processo de difusão e interferência química do dióxido de carbono. Há uma carência de estudos para determinar qual seriam as contribuições de cada uma dessas três possíveis causas, em especial, para a oxi-combustão com gás natural.

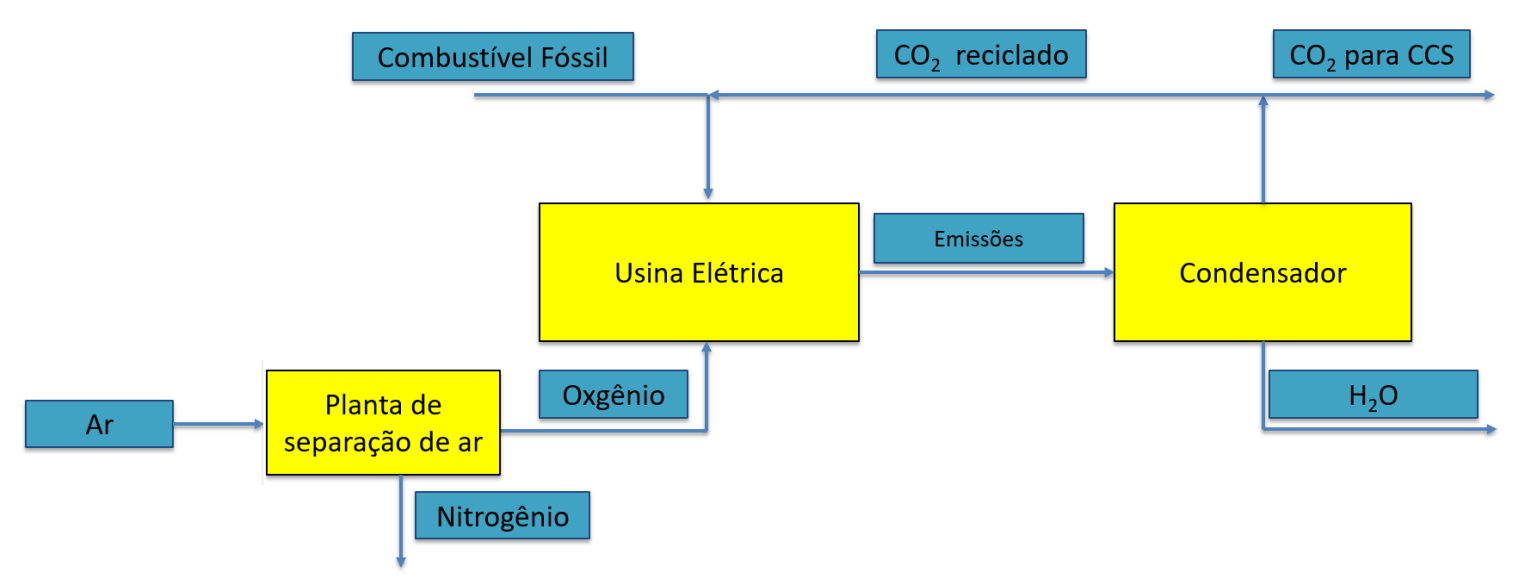

Figura 2 - Esquema de uma usina com CAC e oxi-combustão

Assim sendo, este trabalho aborda quais são as causas das mudanças observadas na oxi-combustão com diluição de dióxido de carbono. Isto posto, a investigação se concentra em avaliar quais das três hipótese propostas pela literatura (alteração de capacidade térmica, difusão e interferência química) para a piora da estabilidade e redução nas taxas de reação tem melhor aderência em relação aos dados coletados durante os experimentos, em especial, foi dada ênfase na hipótese da maior capacidade térmica do dióxido de carbono.

\subsection{Objetivos}

O tema deste trabalho é a oxi-combustão com diluição de dióxido de carbono. Dentro desse, o objetivo é elucidar as causas da mudança de comportamento observada nessa combustão em relação à combustão convencional. $O$ foco é a suposição de que a maior 
capacidade térmica do dióxido de carbono é a responsável pelas alterações relatadas na literatura e observadas nos experimentos.

Além disso, o trabalho tem como objetivos secundários:

- Desenvolver um queimador padrão documentado na literatura para servir como referência.

- Otimizar estratégias de processamento do diagnóstico por quimioluminescência em chamas de oxi-combustão.

- Avaliar parâmetros geométricos das chamas a partir da emissão de radicais $\mathrm{OH}^{\star} \mathrm{e}$ $\mathrm{CH}^{*}$.

- Medir a velocidade de chama laminar em uma oxi-combustão diluída com dióxido de carbono.

\subsection{Estrutura do trabalho}

Para estudar a oxi-combustão são utilizadas duas abordagens: a simulação numérica e a experimentação. As simulações permitem uma abordagem totalmente quantitativa, podem trabalhar com geometrias mais complexas, necessitam apenas de computadores e podem estudar situações muito perigosas para serem testadas em laboratório. Entretanto, toda simulação é construída com modelos derivados da realidade de forma que existe uma incerteza quanto à sua validade. Por isso, é de especial importância, no caso da oxi-combustão, tal averiguação, pois muitos modelos de combustão foram originalmente formulados para combustão convencional. Dessa forma, existem limitações nessas abordagens quando se trabalha com vários oxidantes com composições diferentes ou mesmo para o próprio ambiente de oxi-combustão, quando não há a presença do nitrogênio e o ambiente é muito rico em dióxido de carbono. Assim, nesse estágio de desenvolvimento, a abordagem experimental permite trabalhar com o problema real tentando observar fenômenos, validar hipóteses a respeito do comportamento da oxi-combustão e por fim coletar dados que permitam desenvolver modelos numéricos.

Neste trabalho, os primeiros testes envolveram uma chama de difusão um uma atmosfera controlada. Foi observado quais as diferenças macroscópicas da oxi-combustão em relação à combustão convencional. A chama da oxi-combustão se mostrou menos estável apesar de serem utilizadas concentrações de oxigênio superiores a atmosférica. Essa redução é relatada na literatura, na qual os ambientes ricos em dióxido de carbono tendem a reduzir as taxas globais de reação e reduzindo a estabilidade. Essa mudança de comportamento dificulta a operação dos queimadores o que pode levar a um desperdício de 
combustível ou de oxidante. Nessa problemática o trabalho objetivou avaliar as possíveis causas dessa mudança de comportamento.

Há três hipóteses na literatura para a mudança de comportamento observada na oxi-combustão: as diferenças nas propriedades físico-químicas do dióxido de carbono em relação ao nitrogênio, como a maior capacidade térmica à pressão constante e os diferentes coeficientes de difusão, e a interferência química do dióxido de carbono, pois este é um produto da combustão, portanto sua presença deslocaria os potenciais químicos desacelerando as reações. Sendo assim, este trabalho foca na hipótese que a diferença de capacidade térmica a pressão constante do dióxido de carbono é o principal causador desses fenômenos. Os $C_{p}$ 's do dióxido de carbono e do nitrogênio em base molar à $300 \mathrm{~K}$ são $37,05 \mathrm{kj} / \mathrm{kg}$. K e $29,18 \mathrm{kj} / \mathrm{kg} . \mathrm{K}$, respectivamente, e essa diferença aumenta com a temperatura. Isso ocorre devido ao número de graus de liberdade que a molécula de dióxido de carbono tem em relação ao nitrogênio. O pressuposto é que essa maior capacidade de estocar energia do $\mathrm{CO}_{2}$ reduz a temperatura na oxi-combustão, o que por sua vez diminui as taxas de reação tornando a combustão mais instável.

Primeiramente, para os experimentos foram construídos três diferentes queimadores, os quais permitiram desenvolver as técnicas de diagnóstico de combustão, e que serviram de base para os experimentos de oxi-combustão. Todo esse aparato foi projetado e construído pelos integrantes do laboratório de combustão bem como o autor. Por conseguinte, foram montadas três bancadas de teste, nas quais todos os experimentos foram realizados. Na maioria dos experimentos, foram construídas chamas convencionais, que foram usadas como referencial, e chamas em ambiente de oxi-combustão.

Dentre as diversas técnicas disponíveis para medir o processo de combustão foi escolhida a técnica da quimioluminescência, devido à sua simplicidade e capacidade de determinar a geometria da zona de reação. Nela, a luz emitida pela reação é filtrada antes de ser captada pelo sensor, de forma que se observa a combustão apenas em uma estreita faixa do espectro. Com isso, é possível registrar a emissão luminosa de substâncias químicas presentes na chama as quais emitem luz em bandas bem definidas do espectro. Simultaneamente, partículas de fuligem e o gás carbônico têm uma emissão de amplo espectro ao longo de praticamente todos os comprimentos produzindo um ruído no sinal das outras substâncias. Dentre os diversos componentes que emitem luz na combustão, os radicais químicos se destacam pela forte emissão. Esses radicais são formados durante as diversas reações químicas da combustão como intermediários, assim possuem uma vida curta e existem apenas nas vizinhanças da zona de reação. Os radicais mais observados são o radical $O H^{*}$ (na região de $310 \mathrm{~nm}$ ), $C H^{*}$ (na região de $430 \mathrm{~nm}$ ) e $C 2^{*}$ (nas região de $460 \mathrm{~nm}$ ). A observação direta desses radicais é utilizada para determinar a região da reação (em inglês heat relase region), a estequiometria e a concentração dos radicais. A princípio, essa técnica é qualitativa, mas podem ser feitas inferências quantita- 
tivas medindo distâncias e formatos em uma imagem devidamente calibrada. Para tanto é necessário corrigir possíveis distorções criadas pelo conjunto de lentes, além de construir uma correspondência entre o espaço de imagens e o espaço físico. Para suprir essa demanda foi desenvolvido um procedimento de calibração através de um alvo construído com dimensões conhecidas.

Os dados coletados durante o trabalho não indicaram que há uma boa correlação entre a maior capacidade térmica do dióxido de carbono com as reduções nas taxas globais de reação. Além disso, os resultados indicam uma influência maior da interferência química do dióxido de carbono nas mudança do processo de combustão do que a diferença de $C_{p}$. 



\section{Revisão Bibliográfica}

\subsection{Estado da arte da Tecnologia}

Dentre as várias alternativas existentes para tornar a tecnologia de CAC economicamente viável, a oxi-combustão se destaca pelo elevado grau de desenvolvimento, com testes em escala semi-industrial(ANDERSON et al., 2008; SCHEFFKNECHT et al., 2011). Em Kvamsdal, Jordal e Bolland (2007), foi feito um estudo comparativo da oxi-combustão com outras tecnologias de baixo carbono, comparando a eficiência térmica e a captura de $\mathrm{CO}_{2}$. Nesse estudo, foram selecionados nove diferentes conceitos, três baseados na oxi-combustão: Ciclo SCOC-DC, Ciclo Graz e ciclo Water, outros três baseados em processos químicos alternativos para a combustão: combustão de loop químico (CLC), células de combustível sólidas de óxidos associadas com Turbinas a Gás (SOFC-GT) e Ciclo AZEP. Por fim, os últimos três envolvem o pré-tratamento do combustível fóssil ou o póstratamento das gases de exaustão: Reforma térmica(ATR), pré-combustão com membrana de Hidrogênio(MSR- $H_{2}$ ) e Absorção com Amina. O comparativo foi feito com análises globais dos ciclos, sem se ater a problemas fundamentais nos processos ou dificuldades construtivas.

A figura 3 mostra os resultados das simulações para os diferentes ciclos propostos. Excetuando-se a técnica SOFC/GT, todas apresentaram perda de eficiência em relação ao ciclo tradicional, efeito esperado pelo gasto energético envolvendo a separação e armazenamento do $\mathrm{CO}_{2}$. Vale ressaltar que as células de combustível sólidas de óxido ainda não estão prontas para a aplicação industrial, devido, principalmente, à sua curta vida operacional. Os autores destacam as incertezas devido ao estágio inicial de desenvolvimento de muitas dessas tecnologias e a necessidade de mais estudos na área da combustão em atmosferas ricas em dióxido de carbono.

Outro trabalho(ANDERSON et al., 2008), discute a implementação de uma planta piloto pelo Departamento de Energia do Estados Unidos. Esse projeto foi dividido em três etapas para avaliar a viabilidade dos queimadores de oxi-combustão. Na primeira etapa, foram feitos protótipos laboratoriais que serviram para um estudo fundamental, objetivando a criação de um queimador operacional. Com esse amadurecimento, na etapa seguinte, foi construído um queimador de $5 \mathrm{MW}$. Finalmente, na última fase, um projeto de $170 \mathrm{MW}$, mostrado na figura 4, foi construído. Este queimador possuí duas secções. Na primeira, o combustível é queimado diretamente com o oxigênio, gerando temperaturas da ordem de $3000 K$, logo após, água é injetada em uma secção de diluição para reduzir a temperatura até um valor que uma turbina possa operar. O diferencial deste projeto foi o uso de água líquida como diluente. 


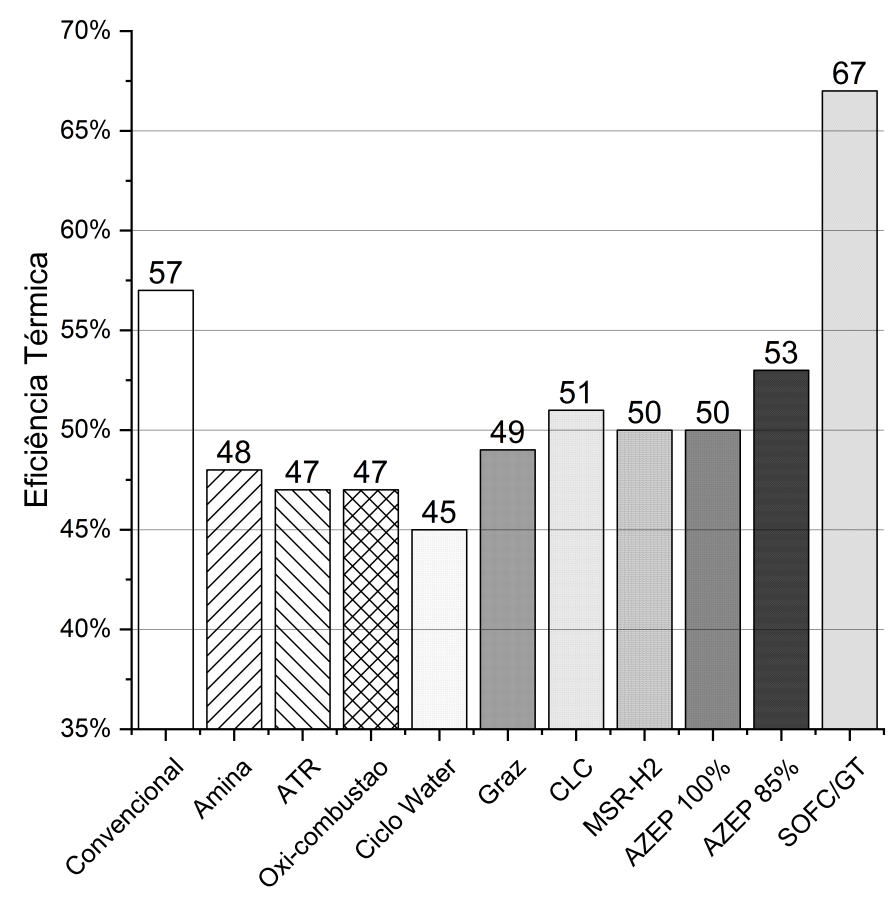

Figura 3 - Comparação da eficiência energética entre o ciclo tradicional e as técnicas de CAC, adaptado de (ANDERSON et al., 2008)

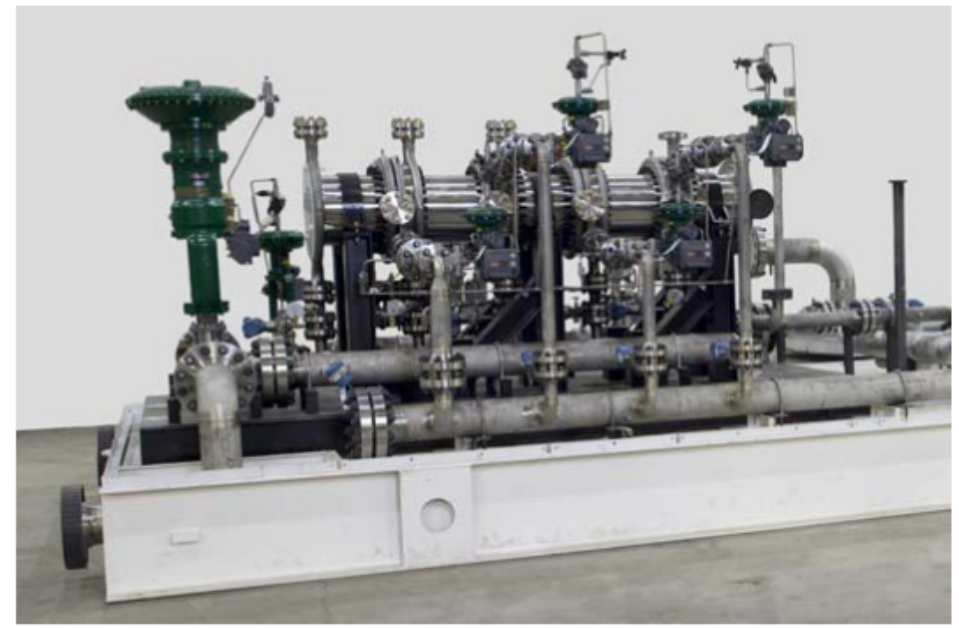

Figura 4 - Queimador de $170 M W$ (ANDERSON et al., 2008)

Outro projeto que construiu queimadores de oxi-combustão, foi desenvolvido por (SUNDKVIST et al., 2014). Nele foi discutido a necessidade de trabalhar com maiores razões de pressão na turbina, a fim de compensar perdas de eficiência, e a dificuldade em manter uma combustão eficiente em atmosferas próximas da estequiometria. Em certas condições foi necessário trabalhar com mais de $30 \%$ de excesso de oxigênio para garantir o funcionamento do queimador, algo que pode inviabilizar o uso em larga escala. Além disso, foi destacado problemas de deposição de fuligem, mudança na transferência de calor e integridade dos materiais nas altas temperaturas. 
O desenvolvimento mais avançado das técnicas de CAC e da oxi-combustão se concentram no uso do carvão mineral. Isso ocorre, pois o carvão é o combustível fóssil mais poluente, o mais utilizado na geração elétrica e aquele que sofre a maior pressão por alternativas ou substituição. Na revisão feita em (SCHEFFKNECHT et al., 2011), algumas das dificuldades relacionadas a oxi-combustão são destacadas, como a mudança na transferência de calor e as alterações no processo de combustão, o que em alguns testes levou ao aumento na produção de compostos sulfurosos e cinzas. Ademais, o gasto energético para a separação do oxigênio e compressão do dióxido de carbono leva a uma redução de $8-12 \%$ na eficiência global da planta em relação à operação tradicional. Para contornar o problema da perda de eficiência foi proposto integrar uma planta de gaseificação (HASEGAWA, 2013), assim o carvão seria convertido em gás, e então queimado em um ciclo combinado ganhando eficiência.

$\mathrm{Na}$ figura[5]são comparadas diferentes técnicas para viabilizar o CAC para plantas a carvão, nota-se um importante ganho de eficiência na oxi-combustão associada com a gaseificação do carvão. Isso reforça a necessidade de melhor compreender a oxi-combustão na fase gasosa, pois permitiria, também, o retrofit de plantas a carvão.

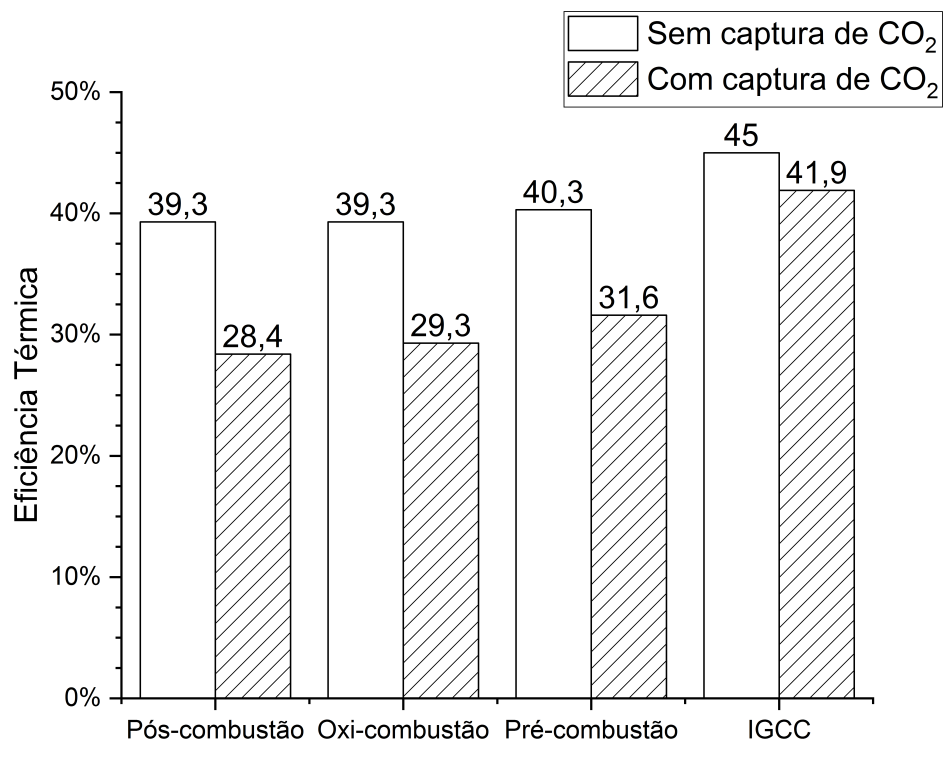

Figura 5 - Comparação entre um ciclo tradicional a carvão com oxi-combustão e um com gaseificação e ciclo combinado, adaptado de (HASEGAWA, 2013)

Outra alternativa, no caso do carvão, é o uso de leitos fluidizados com duas injeções de oxidante de diferentes concentrações de oxigênio a fim de otimizar a oxi-combustão(JIA et al., 2007). 


\subsection{Combustão}

A combustão foi um dos primeiros avanços tecnológicos do homem e permanece como um dos mais importantes, além disso, é um rico tópico de estudo devido a enorme complexidade do processo. Sucintamente, a combustão é uma rápida reação química exotérmica que ocorre no meio gasoso, a qual envolve um combustível e um comburente, podendo ser dividida em combustão pré-misturada e não pré-misturada(TURNS et al., 1996).

Uma combustão pré-misturada é aquela em que o combustível e o oxidante já estão previamente misturados, e é por definição a única que possuí uma frente de chama que se propaga pela mistura(POINSOT; VEYNANTE, 2005). Esse tipo de queima está presente em motores de combustão interna, queimadores industriais e turbinas a gás. Em geral, é um processo de combustão limpo e eficiente, pois a proporção combustível-oxidante é facilmente controlada e não há perdas por heterogeneidade. Entretanto, seu uso acarreta riscos, pois como toda a mistura é inflamável, pode acarretar um retrocesso da chama levando a explosões e acidentes. Um importante parâmetro nesse tipo de chama é a razão de equivalência $\Phi$ que é a relação entre a proporção de combustível-oxidante na mistura pela proporção combustível-oxidante estequiométrica(eq 2.1). Quando a razão de equivalência é inferior a um $(\Phi<1)$, a mistura é considerada pobre e possui excesso de oxidante, quando $\Phi>1$ a mistura é rica e possui excesso de combustível e para $\Phi=1$ a mistura é estequiométrica. Como a razão de equivalência é uniforme ao longo do fluido, a combustão só ocorre para uma faixa de razões ao redor da estequiometria(limites de inflamabilidade).

$$
\Phi=\frac{m_{f} / m_{o}}{\left(m_{f} / m_{o}\right)_{s t}}
$$

Por sua vez, a combustão não pré-misturada, também conhecida por chama de difusão, ocorre quando há duas correntes, uma de oxidante e outra de combustível, que devem se misturar e reagir simultaneamente. Essa tecnologia é amplamente utilizada devido à sua simplicidade e segurança, já que não há o risco de uma propagação da zona de reação causar explosões(TURNS et al., 1996). Neste caso, ocorre uma distribuição espacial do combustível e do comburente de forma que praticamente todas as proporções ar-combustível ocorrem.

$$
\begin{gathered}
D a=\frac{\tau_{\text {int }}}{\tau_{\text {cin }}} \\
K a=\frac{\tau_{\text {cin }}}{\tau_{\text {kol }}}
\end{gathered}
$$

O comportamento dessas chamas variam com o escoamento, pois existe uma interação entre o movimento do fluido e a cinética química. Para caracterizar os diferentes regimes existentes nesse tipo de interação são definidos dois admissionais: o numero de 
Damköhler(eq 2.2) e de Karlovitz 2.3. O primeiro relaciona a escala de tempo integral do escoamento, pela escala de tempo da cinética química, enquanto o segundo correlaciona a escala de tempo das reações, pela escala de tempo de Kolmogorov(POINSOT; VEYNANTE, 2005). Cada tipo de chama possui o seu particular regime para um determinado conjunto e adimensionais. Na tabela 1 são mostrados os regimes para as chamas pré-misturadas por exemplo. Quando todas as escalas da turbulência são maiores que as escalas da química, a zona de reação se aproxima de uma superfície(flamelet). Já no outro extremo, no qual todas as escalas do escoamento são menores, as reações são distribuídas uniformemente por todo o escoamento. Nesses extremos ocorre um desacoplamento entre cinética e turbulência o que simplifica a modelagem. O problema reside na região intermediária, onde os dois processos interagem levando a fenômenos como instabilidade, autoignição, extinção entre outros. Em termos práticos, isso leva a um problema de estabilidade neste tipo de queima, já que idealmente a turbulência deve ser a mais intensa possível para que a mistura ocorra de forma rápida e uniforme. Entretanto, em condições de altas velocidades os radicas podem ser arrastados extinguindo a própria chama no fenômeno de blow-off.

Tabela 1 - Regimes para uma chama pré-misturada turbulenta, adaptado de (POINSOT; VEYNANTE, 2005)

\begin{tabular}{l|l|l}
$K_{a}<1$ e $D_{a}>1$ & $K_{a}>1$ e $D_{a}>1$ & $D_{a}<<1$ \\
\hline Flamelets & Thickened Flames & $\begin{array}{l}\text { Reator perfeitamente } \\
\text { misturado }\end{array}$ \\
\hline $\begin{array}{l}\text { Espessura da frente } \\
\text { de chama é menor } \\
\text { que qualquer escala } \\
\text { da Turbulência }\end{array}$ & $\begin{array}{l}\text { As menores escalas } \\
\text { interagem com a zona } \\
\text { de reação }\end{array}$ & $\begin{array}{l}\text { Todas as escalas são } \\
\text { inferiores à da reação } \\
\text { levando a homogeni- } \\
\text { zação do reator }\end{array}$
\end{tabular}

Pode-se dizer que a estabilidade de uma chama, do ponto de vista macroscópico, consiste em uma reação química que se mantém indefinidamente em uma determinada condição e resiste a pequenas flutuações na condição de operação. No nível microscópico, há um equilíbrio entre a velocidade do escoamento e a velocidade de propagação da reação. Uma estratégia comum para se obter esse equilíbrio consiste em utilizar um corpo onde a chama será "ancorada". Isso ocorre, pois na região próxima ao corpo, pelo efeito da camada limite, a velocidade do escoamento tende a zero e ,devido à transferência de calor e sequestro de radicais, a velocidade das reações também tende a zero, assim ocorre a estabilização e visualmente a chama ancora no corpo. Todavia, essa técnica apresenta problemas, devido à corrosão do material na âncora, superaquecimento dessa região, além de altas velocidades que podem levar ao descolamento da chama, o que limita o seu uso. Outras abordagens para a estabilização incluem: o uso de bluff-bodies que estabilizam a chama na região de recirculação, pré-aquecimento, coflow, chamas-piloto, ecoamento Swirl entre outros. 
Durante a combustão, uma complexa cadeia de reações químicas ocorre em diminutos espaços de tempo $\left(\approx 10^{-8} s\right)$, levando à conversão dos reagentes nos produtos. O balanço global das reações de combustão não explicita o caminho que as substâncias percorrem, ligando apenas o estado inicial e o final. Por uma questão estatística, na maioria das reações ocorre apenas o encontro entre duas moléculas, já que a probabilidade desse evento é em ordens de grandezas maior do que o encontro entre várias moléculas simultaneamente. Desse modo, para se construir um percurso de uma conversão química próximo do real, deve ser determinada a sequência de reações biomoleculares e eventuais trimoleculares, pelas quais os reagentes se tornam os produtos. No caso particular da combustão, cada reação segue o modelo da equação de Arrhenius (POINSOT; VEYNANTE, 2005). Existem diversos mecanismos, cobrindo desdes os mais simples(globais) com poucas ou apenas uma equação, até os mais refinados com dezenas de equações e centenas de espécies que tentam se aproximar do processo real. Independente do mecanismo, todos devem ser calibrados com base em dados experimentais. Nesse procedimento as reações químicas ocorrem no interior de um reator controlado e instrumentado permitindo a medição simultaneamente de diversas espécies químicas ao longo do tempo em uma dada temperatura, como feito em (GIMÉNEZ-LÓPEZ et al., 2015).

Para o metano o mecanismo mais consagrado e estudado é o GRI3.0 que foi avaliado em experimentos de velocidade de chama laminar (MAAREN; THUNG; GOEY, 1994), de Ignição em Shock-Tubes (WOIKI et al., 1998) e em reatores isotérmicos (ALZUETA; GLARBORG; DAM-JOHANSEN, 1997).

No caso particular da oxi-combustão com oxidante rico em dióxido de carbono, diversos estudos experimentais e numéricos (LIU et al., 2001; GLARBORG; BENTZEN, 2007; MENDIARA; GLARBORG, 2009; GIMÉNEZ-LÓPEZ et al., 2015 observaram uma redução nas taxas de reação e temperatura da zona de reação. A causa deste efeito ainda é controversa, há autores que o relacionam com a maior capacidade térmica do dióxido de carbono em relação ao nitrogênio, o que levaria a uma redução na temperatura e por conseguinte nas taxas de reação(LIU et al., 2001). Outros autores focaram no papel químico do dióxido de carbono, substancialmente diferente do nitrogênio, pois esse participa ativamente nas reações químicas em especial na reação 2.4 (GIMÉNEZ-LÓPEZ et al., 2015). Assim, um excesso de dióxido de carbono desloca a reação 2.4 para o lado direito consumindo radicais $H$, o que leva a uma redução global das taxas de reação. Para avaliar este efeito foi feita uma simulação da cinética química de uma CounterFlow difussion Flame.

A figura 6 mostra um diagrama desse reator. Essa simulação compreende apenas a linha central do queimador permanecendo unidimensional, o que reduz drasticamente o tempo computacional, pois a simulação utilizará o mecanismo químico detalhado cuja integração já oferece um desafio numérico. Já a figura $6 \mathrm{~b}$ mostra a máxima temperatura na simulação pelas diferentes composições do oxidante. Como era esperado, o aumento 


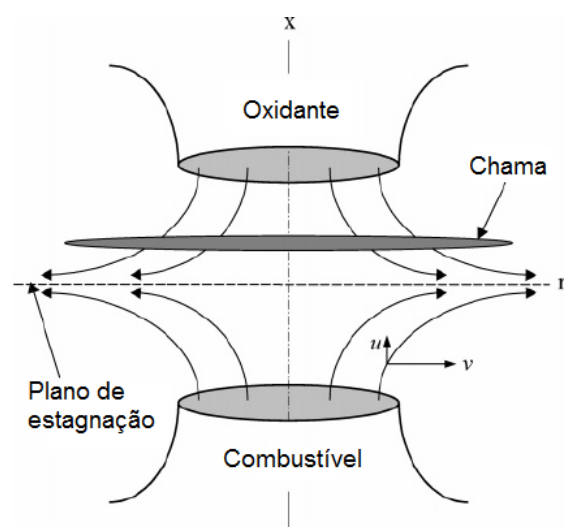

(a) Esquema de um queimador de difusão e contra-corrente

Temperatura Adiabática de Chama

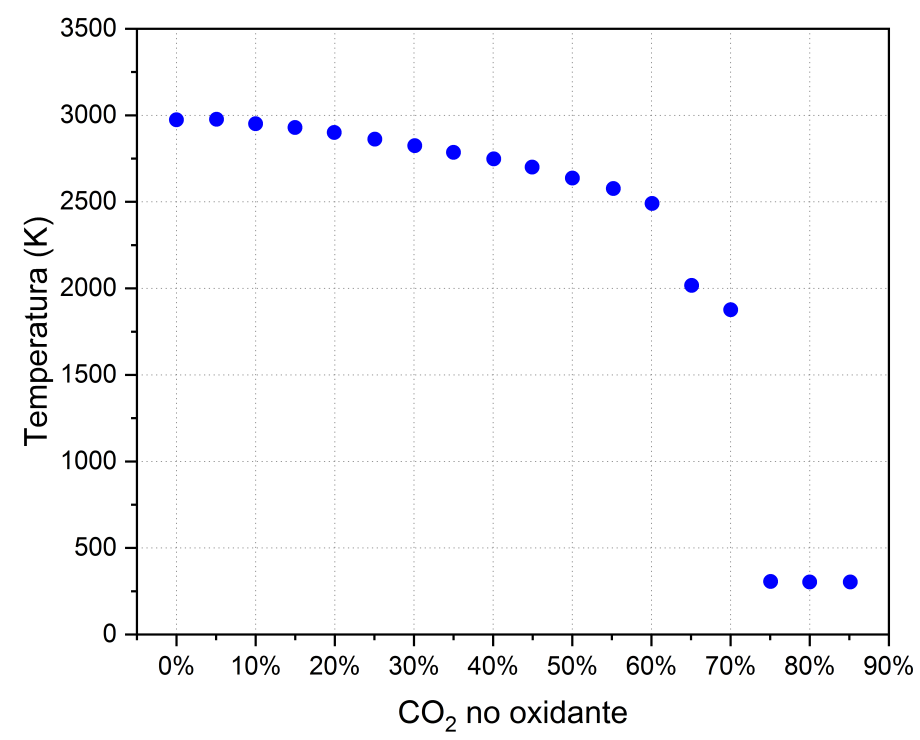

(b) Simulação da máxima temperatura na linha central para oxidantes com diferentes composições

Figura 6 - Simulação da cinética química de oxi-combustão para oxidantes com diferentes concentrações de dióxido de carbono

na concentração de dióxido de carbono vai reduzindo a temperatura, entretanto quando a sua concentração supera os $60 \%$ a queima torna-se instável com uma súbita redução na temperatura até que com mais de $70 \%$ a reação deixa de ocorrer, mesmo com uma concentração de oxigênio superior à presente na atmosfera.

$$
\mathrm{CO}_{2}+\mathrm{H}^{*} \leftrightarrow \mathrm{CO}+\mathrm{OH}^{*}
$$

Outra preocupação reside na adequação dos mecanismos já desenvolvidos, como o GRI3.0, para a oxi-combustão no estudo experimental e numérico feito por (GIMÉNEZLÓPEZ et al., 2015), tendo em vista que este modelo apresentou boa aderência aos dados experimentais, sendo validado para essa condição. 
Os jatos são amplamente utilizados em queimadores devido à sua simplicidade e robustez de funcionamento. Sua chama é formada por um jato de combustível ou prémistura que queima dentro do ambiente desejado como um forno ou uma câmara de combustão de turbina a gás. Na situação de uma chama de difusão, o combustível avança ao longo do eixo do jato ao mesmo tempo que se espalha radialmente na direção do oxidante, o qual caminha no sentido oposto ao do combustível até que por fim acabam por se misturar na zona de reação onde se forma a chama(POINSOT; VEYNANTE, 2005)(TURNS et al. 1996). Para pequenas velocidades, a chama forma um envelope ao redor do jato praticamente encostando na ponta do injetor, ou seja, a chama está ancorada. Porém, conforme a velocidade do jato aumenta a região de combustão começa a descolar do tubo até transicionar para uma condição de chama lifted, como mostrado na figura 7, obtida experimentalmente por (PLESSING et al., 1998). Nesse regime a altura na qual a chama estabiliza é um importante parâmetro a ser avaliado, pois ela depende do equilíbrio entre o escoamento e a cinética química. Além disso, devido a mistura que ocorre antes da zona do início da combustão essa chama passa a ser denominada parcialmente pré-misturada, devido à formação de regiões com pŕe-mistura. Em alguns casos é formada uma chama tripla, na qual coexistem uma chama de difusão e duas de pré-mistura(uma rica e outra pobre). Esse tipo de estrutura é de fundamental importância para o entendimento de como as chamas lifted não pré-misturas se estabilizam e como em certas regiões reignitam depois de serem extintas por altas velocidades ou turbulência(AZZONI et al., 1999). Entretanto para velocidades muito altas não há como a reação química se manter estável, pois o ocorre o blowout da chama.

Esse tipo de chama é amplamente estudada devido à sua simplicidade construtiva, possibilidade de utilização de técnicas de diagnóstico a laser, ao mesmo tempo que apresenta diversos fenômenos físicos relevantes e similaridade com os queimadores utilizados em escala industrial. Os estudos nesse tipo de chama podem ser divididos em dois grandes ramos: jatos em ambientes frios e em ambientes quentes. Ambos são conduzidos há décadas porém ainda não há consenso sobre quais os mecanismos responsáveis por manter a estabilidade da chama, em especial, quando estão lifted e em ambientes frios (CHEN; HERRMANN; PETERS, 2000).

Em relação às chamas em jatos em ambientes quentes, a série de estudos realizados no Sandia National Laboratories se tornou referência para diversos trabalhos. Os queimadores utilizados criavam o ambiente aquecido a partir de chamas piloto que produzem um Coflow quente ao redor da chama principal, isolando-a do ar atmosférico, como visto na figura 9 .

Foram feitas medições ópticas com Raman, Rayleigh, LIF and PIV para caracterizar essas chamas e estudar a interação entre as diversas regiões do escoamento e da chama(MASRI; DIBBLE; BARLOW, 1996; BARLOW et al., 2001). Um dos desafios do 

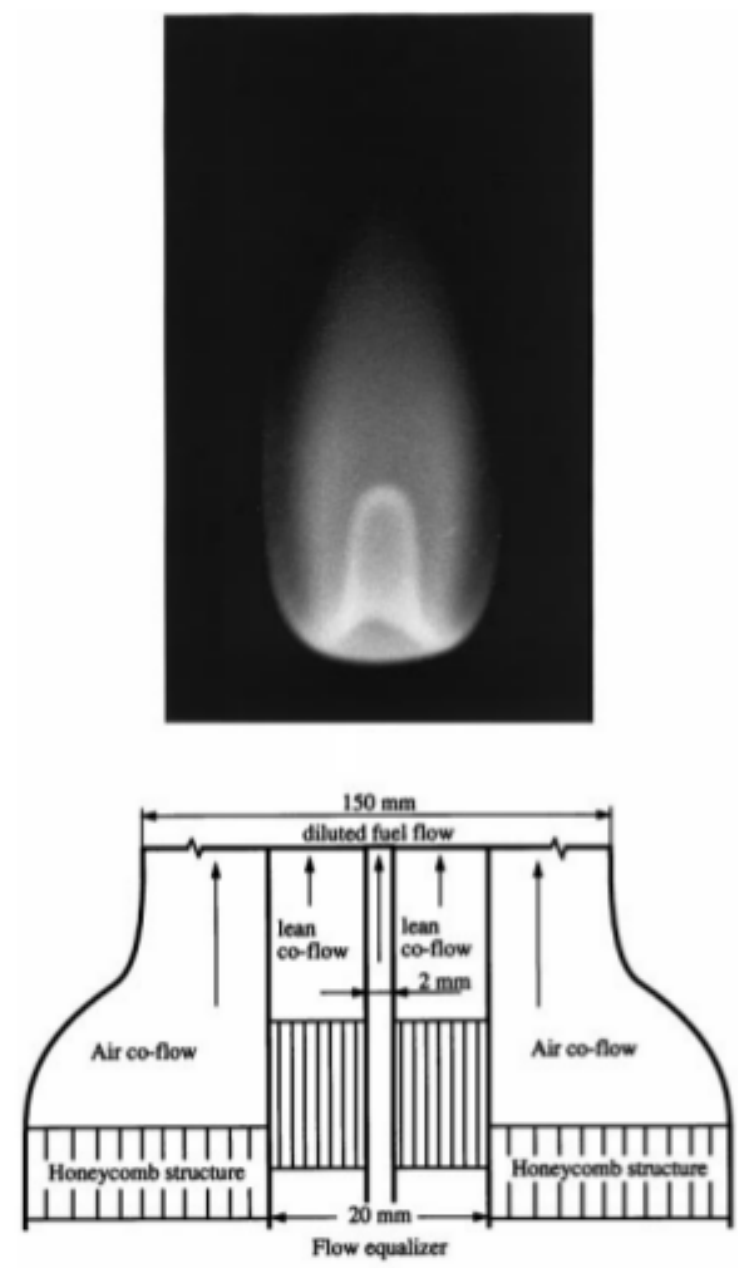

Figura 7 - Chama suspensa, adaptado de (PLESSING et al., 1998)

ponto de vista experimental é o controle da formação do Coflow, já que como mostrado na análise de sensibilidade feita por (ROWINSKI; POPE, 2011) pequenas flutuações nas condições do Coflow têm grande impacto no comportamento da zona de reação e na transferência de calor. Na parte numérica, a riqueza de dados e a simplicidade da geometria estimulam um grande desenvolvimento, permitindo estressar os modelos, como no trabalho de (VREMAN et al., 2008) em que o modelo de química tabelada via Flamelet foi testado para as chamas de Sandia tipo D e F.

No caso de chamas em ambientes frio, o meio pode ser tanto quiescente ou apresentar um Coflow de baixa velocidade. Não há consenso sobre qual o mecanismo responsável pela estabilização dessas chamas, sendo um tópico de debate até os dias atuais. Uma das hipóteses propostas é que há um equilíbrio entre a velocidade de chama turbulenta e a velocidade do escoamento, essa explicação remonta aos primeiros trabalhos nessa área como o de (WOHL; KAPP; GAZLEY, 1948). Nela a região anterior à chama deve ser capaz de produzir uma pré-mistura em quantidades significativas. No estudo experimental realizado por (EICKHOFF; LENZE; LEUCKEL, 1985), 40-50\% do combustível 


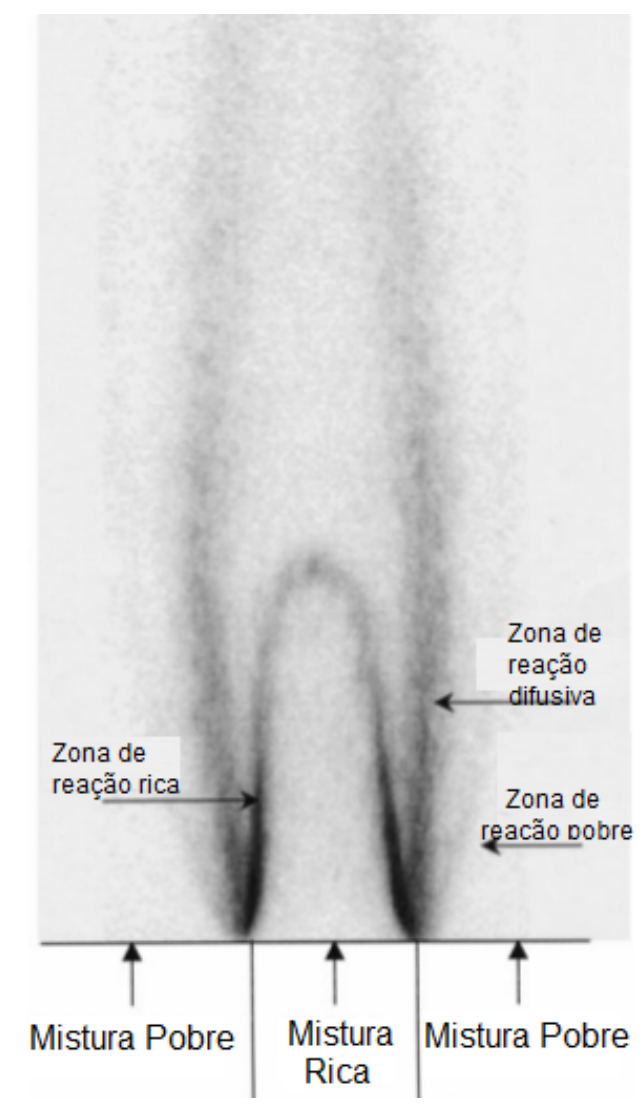

Figura 8 - Quimioluminescência de uma chama tripla, adaptado de (AZZONI et al., 1999)

se misturou em nível molecular ao comburente antes da base da chama. Uma abordagem recente desse mecanismo é que ao invés de se formar uma única pré-mistura, criam-se duas(uma rica e outra pobre), formando uma estrutura de chama tripla com um complexo equilíbrio entre diversas velocidades de propagação. 


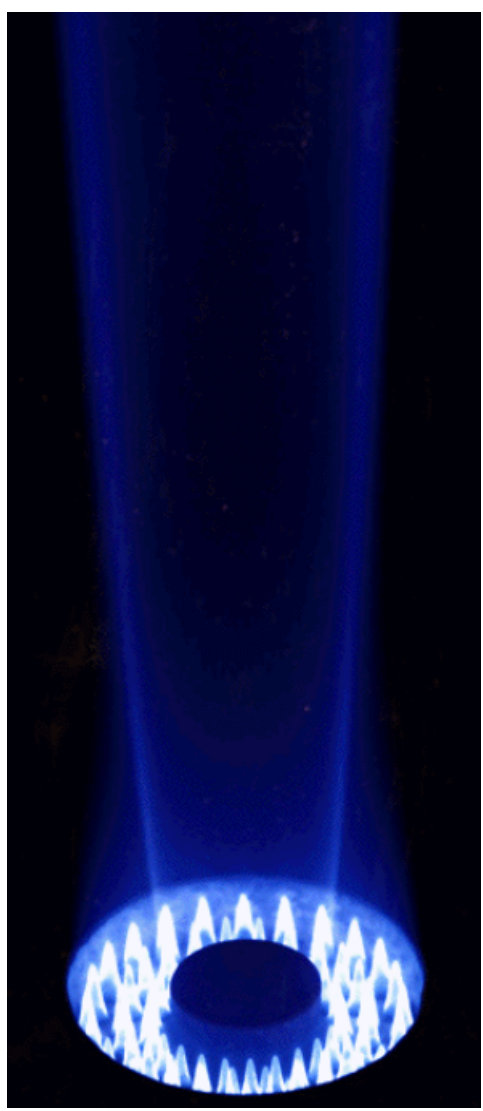

Figura 9 - Chama de difusão envolta em um Coflow de chamas pilotos, adaptado de (MASRI; DIBBLE; BARLOW, 1996) 



\section{Materiais e Métodos}

Neste trabalho foram construídos três queimadores com o objetivo de se investigar a oxi-combustão com diluição de dióxido de carbono. Além disso, foram trabalhadas as técnicas de medição por anemometria de fio quente e quimioluminescência. Um dos desafios foi adequar os experimentos propostos às capacidades do laboratório de combustão, onde no decorrer do desenvolvimento dos trabalhos passou por uma extensa reforma. Apenas com essa adequação das instalações laboratórias foi possível a realização dos trabalhos.

\subsection{Queimadores}

A investigação da oxi-combustão utilizou três configurações de queimadores. O primeiro queimador projetado e construído foi baseado no trabalho Smooke et al. (1999), doravante queimador Yale, esse é um pequeno queimador com uma chama central em meio a um escoamento secundário não reativo. As figuras $10 \mathrm{a}$ e $10 \mathrm{~b}$ mostram o desenho de montagem do queimador e o seu modelo em CAD. Esse equipamento foi construído originalmente para estudar a formação de fuligem em chamas laminares de difusão. Nessa configuração, o combustível é injetado pelo tubo central enquanto um outro gás (ar no trabalho original) circunda essa chama formando um escoamento secundário (Coflow) à temperatura ambiente. O injetor de combustível consiste em um tubo de aço inoxidável com diâmetro externo de 4,76 mm (3/16") e interno de 3,97 mm (5/32"). Enquanto o gás que envolve a chama central entra no corpo principal do queimador por quatro mangueiras dispostas simetricamente em conexões NPT de 1/8". O corpo do queimador consiste em um cilindro de alumínio com um diâmetro externo de $89 \mathrm{~mm}$ e comprimento de $82 \mathrm{~mm}$. O gás entra em uma cavidade com diâmetro de $76 \mathrm{~mm}$ e a altura de $32 \mathrm{~mm}$, esse pequeno pleno objetiva equalizar o escoamento vindo das quatro entradas. No seu topo há um honeycomb de Hasteloy-X(B)com células de tamanho 0,79 mm (1/32"), que é sustentado por um prolongamento da tampa inferior de alumínio que o pressiona contra um rebaixo acima. Esse rebaixo ocorre devido à contração do diâmetro interno que passa a ser $73 \mathrm{~mm}$ pelos próximos $45 \mathrm{~mm}$. Esse espaço é preenchido com esferas de vidro, com diâmetro médio de $3 \mathrm{~mm}$ com precisão de 0,3 $\mathrm{mm}$. Com a perda de carga induzida por essas esferas de vidro, espera-se homogenizar o escoamento secundário. Por fim, no topo do queimador o diâmetro volta a ser $76 \mathrm{~mm}$, criando um pequeno assento para outro honeycomb igual ao anterior. Tanto as esferas de vidro como o honeycomb operam como retificadores de fluxo para garantir um escoamento secundário o mais homogêneo possível.

A figura 11a mostra o primeiro teste feito com o queimador pronto, o qual serviu apenas como uma prova de conceito. Ao lado, na figura $11 \mathrm{~b}$, é mostrado o queimador 


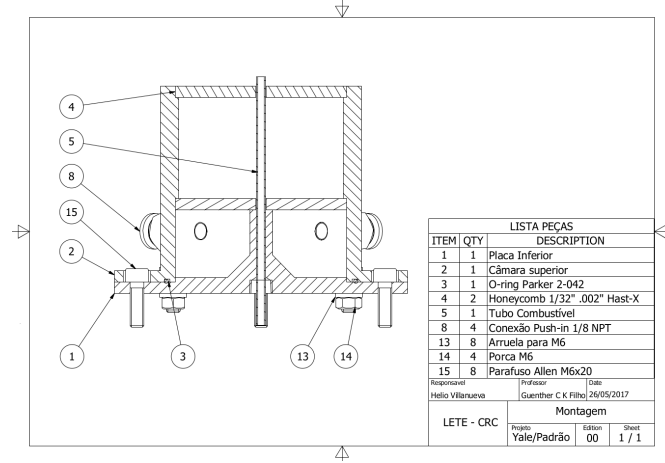

(a) Desenho de montagem

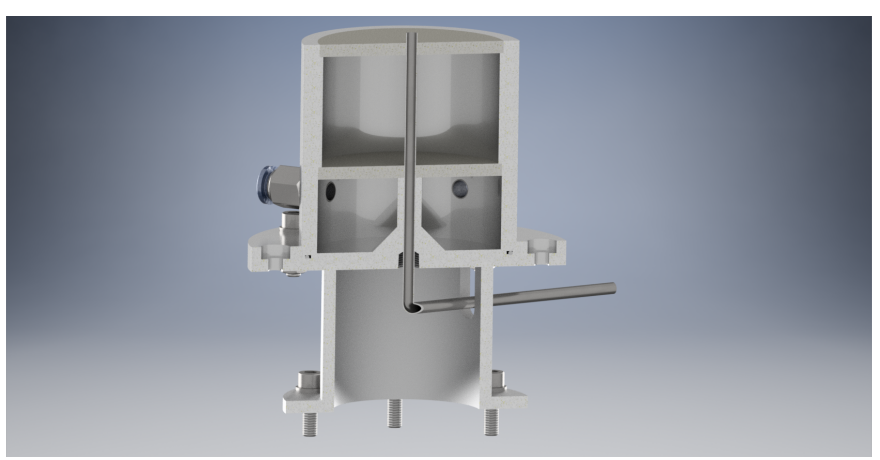

(b) Vista em corte do modelo 3D do queimador

Figura 10 - Projeto do queimador

pronto após receber uma pintura eletrostática preta a fim de reduzir reflexões durante as medições ópticas.

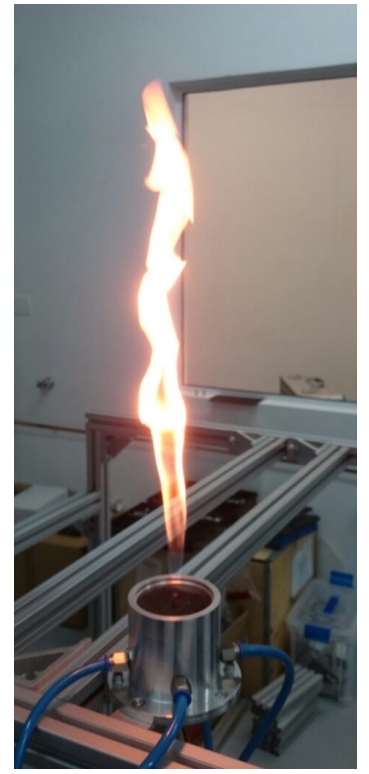

(a) Foto do primeiro teste com o quei- (b) Fabricação finalizada com retificadores de fluxo instamador

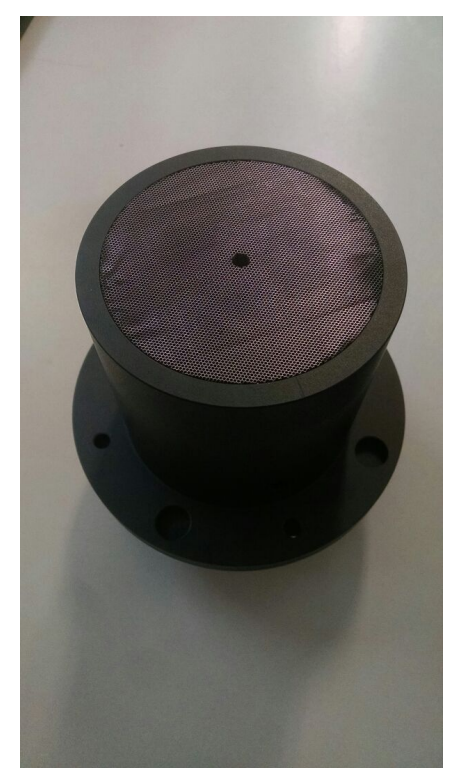
lados e pintura pronta

Figura 11 - Queimador Yale

Apesar dos retificadores de fluxo não há garantia prévia de um escoamento homogêneo. Por isso, foi utilizado a técnica da anemometria por fio quente, a fim de avaliar a homogeneidade do escoamento secundário, medindo velocidade ao longo do raio do queimador. Utilizou-se uma sonda unidimensional, avaliando apenas a magnitude da velocidade. Sendo que, o parâmetro estudado para melhorar a uniformidade do escoamento foi o volume preenchido pelas esferas de vidro, visto que nos trabalhos originais não foi explicitado. Assim, o primeiro estudo consistiu em determinar o volume ótimo de esferas para equalizar o fluxo de gás. Em seguida, puderam ser realizados os ensaios com combustão nesse queimador. 


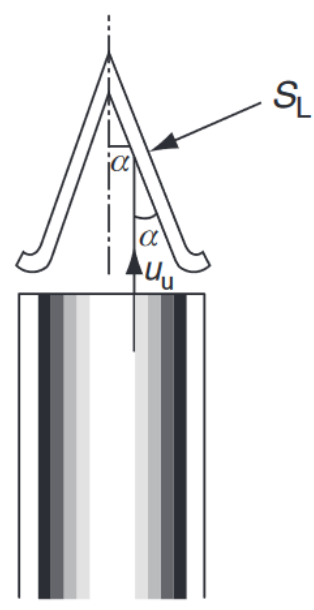

Figura 12 - Ilustração da chama cônica, adaptado de Glassman, Yetter e Glumac (2014)

Por ser um queimador pequeno, o queimador Yale é mais adequado para estudos com chamas laminares de difusão. Nos testes em atmosfera controlada, a chama central foi isolada do ar atmosférico com um tubo de quartzo, de forma a se criar uma atmosfera controlada através do escoamento secundário.

$\mathrm{Na}$ continuação do estudo da oxi-combustão foi proposto um queimador que permite medir a velocidade de chama laminar, já que esse é um importante parâmetro da combustão. Para isso, foi selecionado a técnica da chama cônica. Nela, uma chama laminar pré-misturada de perfil cônico é construída. $\mathrm{O}$ angulo desse cone $(\alpha)$ e a velocidade média do jato $\left(u_{U}\right)$ se correlacionam com a velocidade laminar pela expressão 3.1 . Essa abordagem é uma das mais simples de se construir experimentalmente, entretanto apresenta algumas limitações e as maiores incertezas (em geral,acima de 5\%) de todas as técnicas comumente utilizadas (GLASSMAN; YETTER; GLUMAC, 2014). Nessa é necessário um fornecimento constante de gás e um perfil de velocidades bem definido na saída do tubo. Além disso, a velocidade não é constante ao longo da chama, ela diminui próximo às paredes do tubo do queimador e aumenta no topo onde ocorre uma curvatura. Assim, para conseguir uma medida mais precisa da real velocidade de chama laminar é necessário tomar o ângulo a partir da seção média do cone. Ainda assim, a velocidade é na realidade diferente em cada ponto da chama cônica, por essa razão essa abordagem apresenta uma incerteza maior em relação a outros métodos como a chama plana, mas com a vantagem construtiva.

$$
S_{L}=u_{U} \operatorname{sen} \alpha
$$

Baseado no que seria um queimador cônico ideal(figura 12) foi feito um projeto simples de um tubo metálico de aço inox com $150 \mathrm{~mm}$ de comprimento e diâmetro interno de $10 \mathrm{~mm}$ acoplado a uma saída de gás. A figura 13 mostra o queimador construído. $\mathrm{O}$ 
tubo principal é preso por parafusos a uma base de bronze de alumínio que é então fixada as estruturas de alumínio que suportam os experimentos.

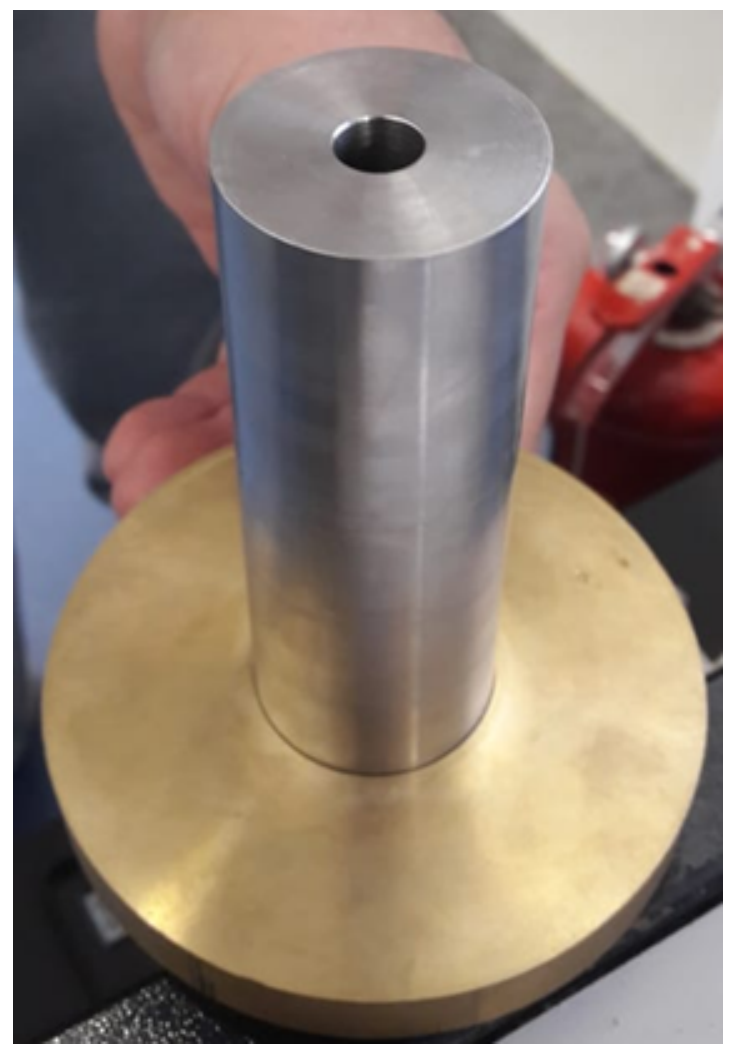

Figura 13 - Queimador de chama cônica

Por fim, para estudar a oxi-combustão em chamas turbulentas foi construído, pelo autor, mais um queimador baseado no trabalho desenvolvido por Cabra et al. (2005). Este consiste em uma injeção de combustível ou pré-mistura dentro de um grande fluxo secundário reativo, composto pelos produtos de combustão de pequenas chamas pré-misturas. Desta forma, a chama interna fica isolada do ar atmosférico, mesmo sendo um queimador aberto, sem um tubo de quartzo para isolar a chama, por exemplo. Isso é particularmente útil em estudos ópticos, porque qualquer tipo de meio entre o local de medição e a câmera pode distorcer ou reduzir à emissão luminosa. No estudo original foram avaliados parâmetros geométricos da chama (altura da chama suspensa) e medições pontuais de temperatura e composição química.

O esquema mostrado na figura14a ilustra o design do queimador. Há uma placa perfurada de latão, com $210 \mathrm{~mm}$ de diâmetro e 12,7 mm de espessura no escoamento secundário que suporta as chamas pré-misturadas. A área livre total dessa placa representa $87 \%$ da área da placa devido aos 1890 furos passantes de $1,58 \mathrm{~mm}$ de diâmetro. Chamas de jato de gás natural pré-misturadas com ar foram estabilizadas em cada orifício, e seus produtos misturados para formar o escoamento secundário viciado. $O$ jato principal flui de um tubo de aço inoxidável (6,35 mm o.d. / 4,57 mm d.i.), que se estendia $70 \mathrm{~mm}$, além da superfície da placa perfurada. As adaptações feitas na configuração original ocorreram 


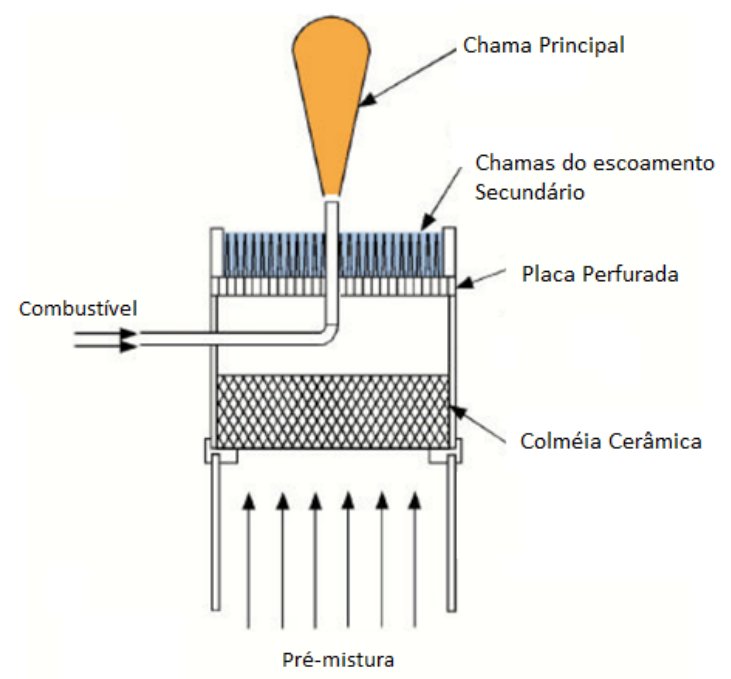

(a) Esquema construtivo do queimador,adaptado de Cabra et al. (2002)

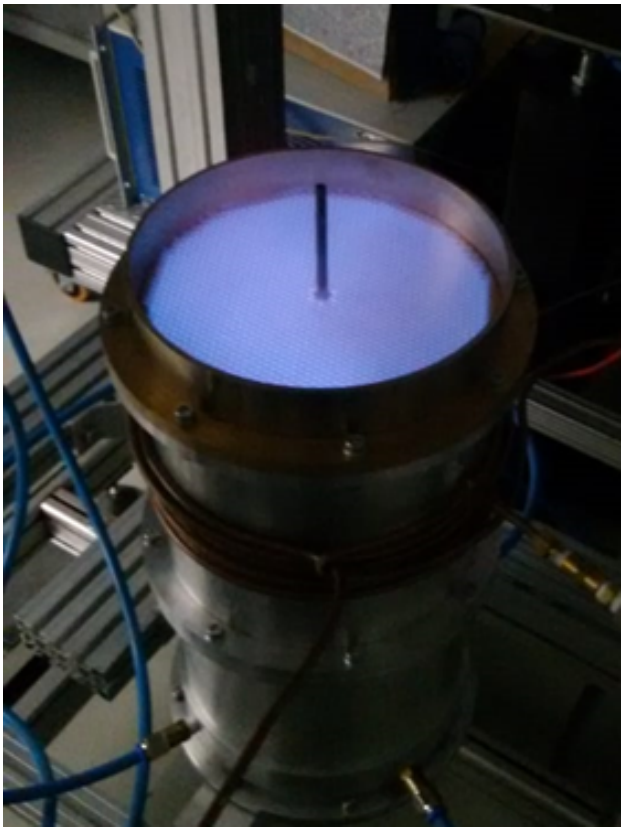

(b) Equipamento construído pelo autor

Figura 14 - Imagens do queimador cabra

na região de formação da pré-mistura, pois o trabalho original não detalha o projeto dessa região. Um dos itens especificados foi um honeycomb cerâmico utilizado no catalisador de caminhões, graças à doação da OMINICORE foi utilizado uma cerâmica seguindo as especificações do trabalho original.

Para a secção de mistura foi confeccionado, pelo autor, dois tubos de alumínio flangeado que servem de região de formação de pré-mistura, além de suporte estrutural para o queimador. Na parte inferior do queimador uma válvula de segurança foi instalada que permite o rápido alívio dos gases caso haja um engolimento da chama e uma explosão na região de formação de pré-mistura. Os gases são alimentados por quatro tubos dispostos simetricamente na base do queimador.

\subsection{Instalações laboratoriais}

Todos os experimentos foram realizados nas instalações do laboratório de combustão (LETE-CRC), durante os trabalhos deste projeto foi realizada uma grande reforma nesse laboratório, a qual o autor participou ativamente, a qual focou na adequação das instalações as normas de segurança para que se pudesse operar seguramente com chamas no seu interior. Além disso, foram instaladas linhas de fornecimento de gás para abastecer os queimadores e vasos de pressão lá testados.

O subsistema de fornecimento de gás se inicia no exterior do laboratório com casamatas, especificadas pela norma, que estocam os cilindros. Em seguida, linhas de inox levam os gases até o interior do laboratório. Por fim, essas linhas terminam em regulado- 


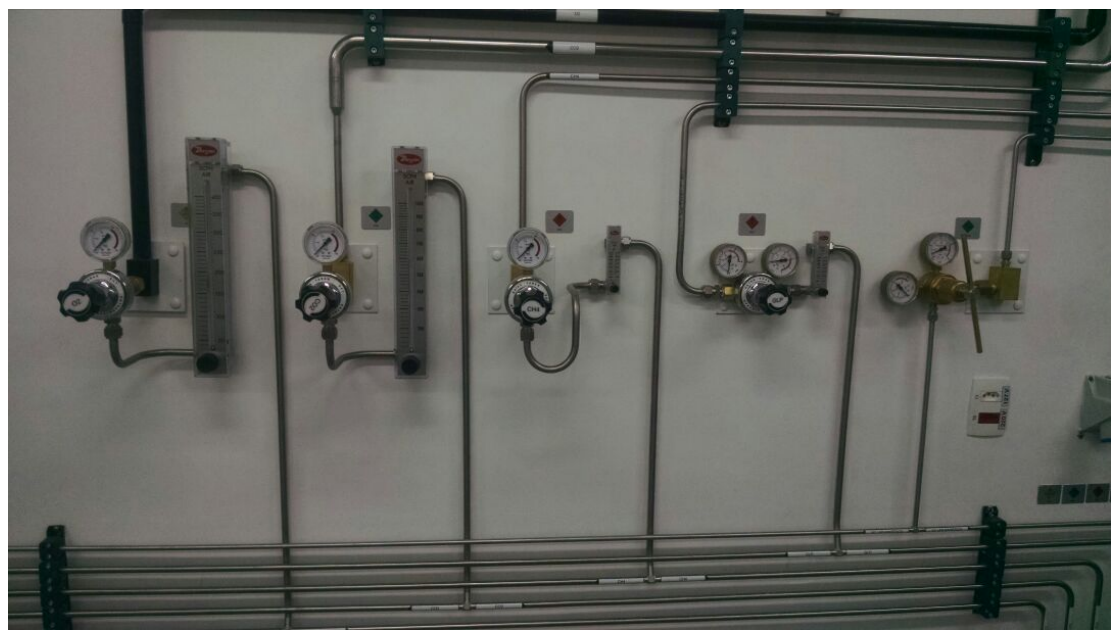

Figura 15 - Distribuição de gás na parede interior do laboratório

res de pressão e controladores de vazão na parede lateral no interior do laboratório de combustão (figura 15).

As instalações foram equipadas com um sistema automatizado de segurança, que consiste em uma série de sensores de gases espalhados pelo espaço de testes, os quais monitoram os níveis de explosividade e de oxigênio. Assim, monitoram os riscos de explosões devido ao acúmulo de gases inflamáveis e o risco de sufocamento devido à utilização de gases asfixiantes (figura 16a). Além disso, há uma série de válvulas solenoides nas linhas de gás que cortam o fornecimento em caso de emergência ou queda de energia. Ademais, um sistema de ventilação mantém o ar na região dos experimentos sendo constantemente renovado para reduzir o risco de incêndios ou asfixia. A figura $16 \mathrm{~b}$ mostra uma das duas coifas utilizadas para conter os gases emitidos durante a combustão. Por fim, uma série de reles atuados permite que a energia seja cortada caso a concentração de gases explosivos atinga um patamar perigoso. Todos esses diferentes sistemas são monitorados por uma central de alarmes e um painel unificado que registra continuamente os níveis de gases, a liberação das válvulas e o acionamento dos ventiladores (imagens 17a e 17b). Essa central unificada é a responsável por acionar os dispositivos de segurança caso algum dos sensores indique uma condição de perigo, assim durante os experimentos a sala é monitorada constantemente por esse sistema de segurança.

As instalações também são equipadas com calhas organizadoras, visíveis na figura $16 b$, que permitem que o cabeamento utilizado durante os experimentos seja suspenso desobstruindo o caminho. Além do mais, para reduzir o risco de faíscas e acumulo de estática nos equipamentos um barramento aterrado percorre todas as paredes do laboratório criando um ponto de aterramento em comum para todos os equipamentos e bancadas. $O$ aterramento dos experimentos é de grande importância, pois o ambiente do laboratório é mantido à baixa umidade para prolongar a vida útil dos lasers e câmeras. Entretanto, isso propicia o acumulo de eletricidade estática de modo que não é incomum pequenas faíscas 


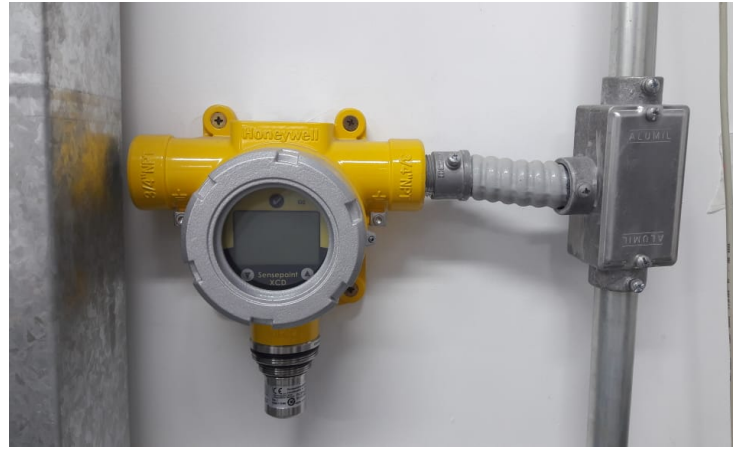

(a) Sensor de gás

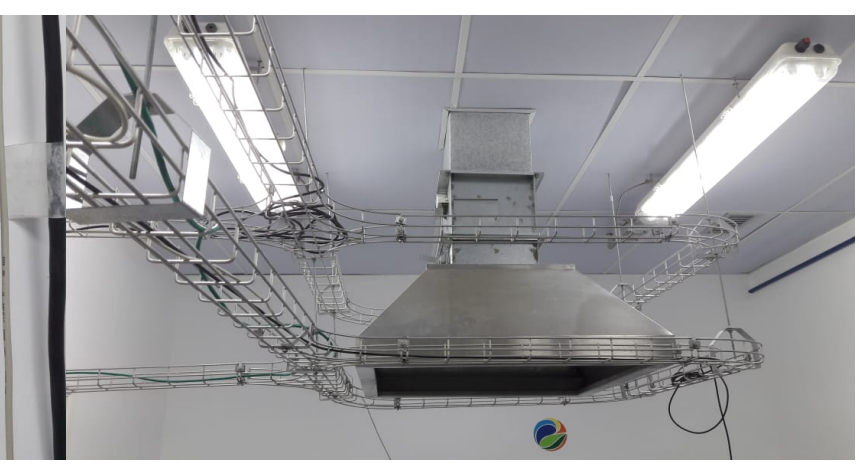

(b) Coifa da ventilação

Figura 16 - Subsistema de segurança

quando os equipamentos não estão aterrados adequadamente.

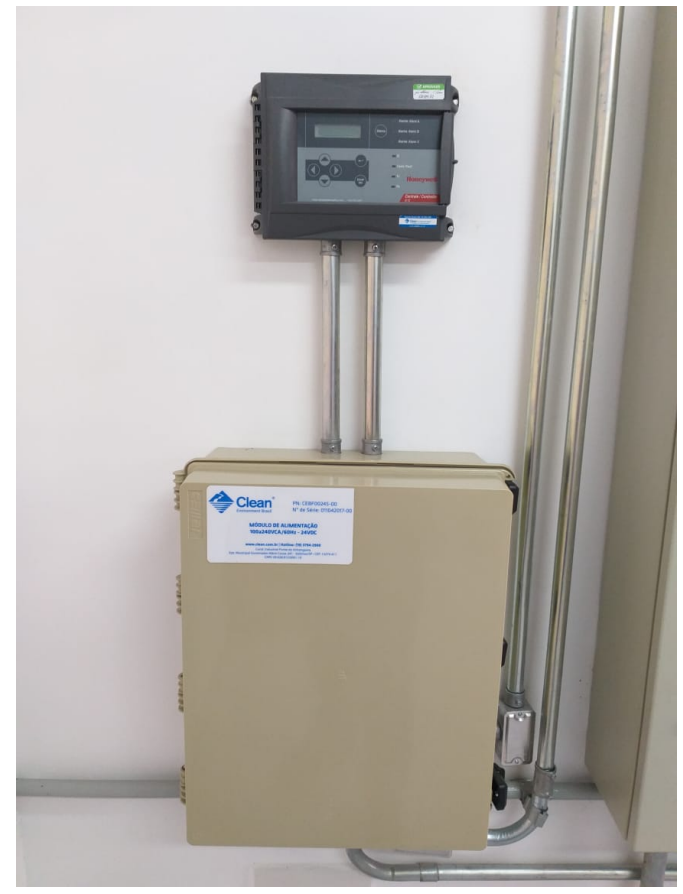

(a) Central de alarmes

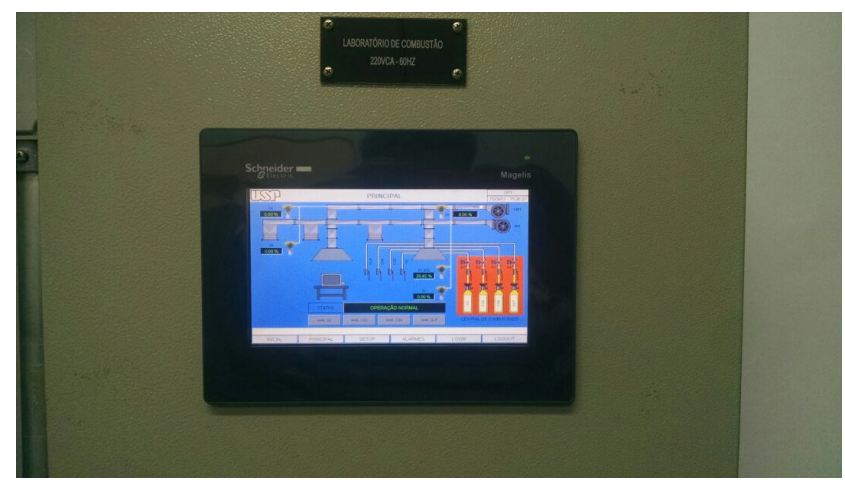

(b) Painel principal de controle

Figura 17 - Subsistema de segurança

Para controlar o fluxo dos gases nos diversos experimentos foram utilizados rotâmetros de esfera (figura 18). Esses equipamentos de baixo custo permitem regular manualmente a vazão de gás e podem ser utilizados com diferentes gases desde que sejam feitas correções. No entanto, o valor da vazão é função da gravidade específica do gás e da pressão a montante, o que ocasiona uma maior incerteza, porque podem haver variações desses parâmetros ao longo do experimento. Essa maior incerteza se reflete na escala do equipamento. Por outro lado, o seu baixo custo e disponibilidade tornaram esse o controlador de vazão utilizado no laboratório.

Por fim, para a aquisição dos dados foram empregadas câmeras de alta veloci- 


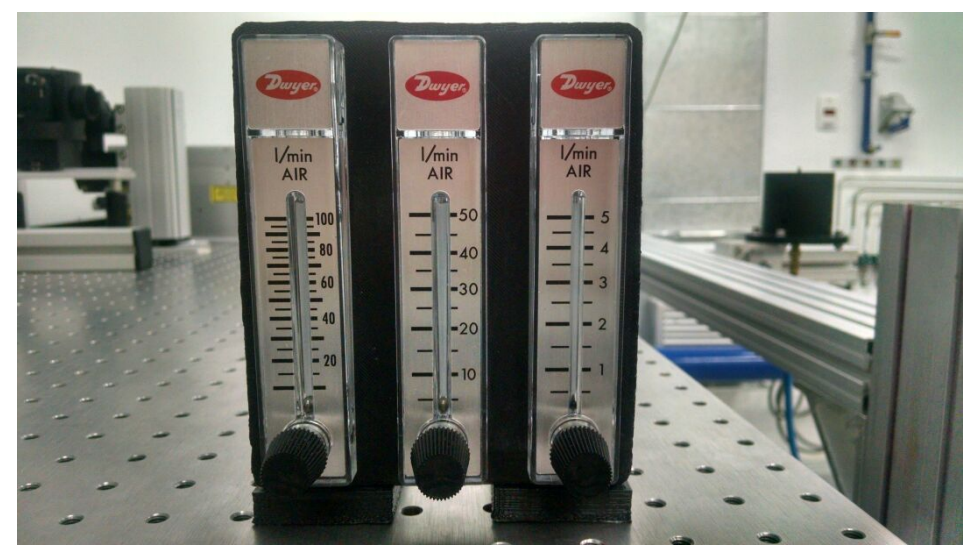

Figura 18 - rotametros

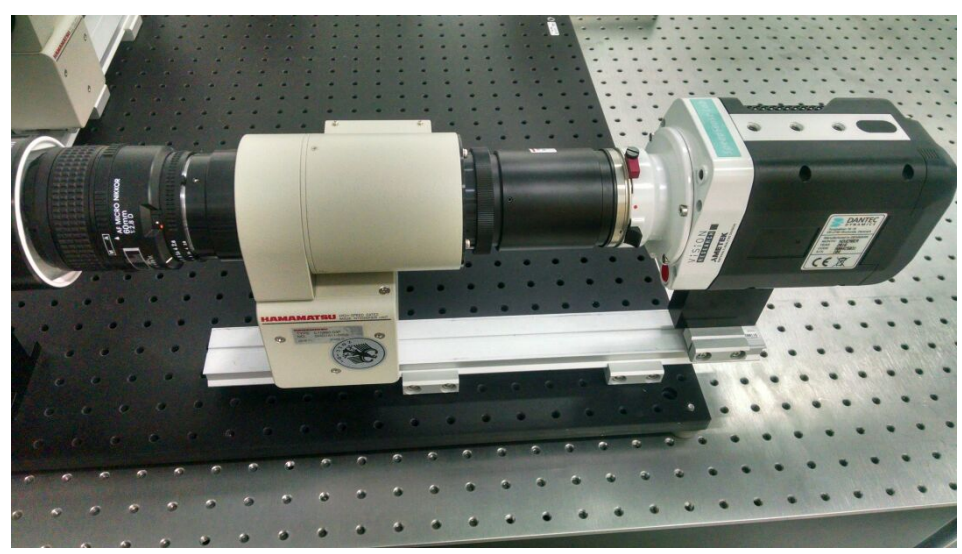

Figura 19 - camera

dade(figura 19) capazes de captar emissões luminosas no espectro visível. Para realizar as observações em comprimentos de ondas específicos foram utilizados filtros ópticos passa banda de alta transmissibilidade(superior a 80\%). Entretanto, o sensor das câmeras não é sensibilizado pela luz ultravioleta, assim para poder observar emissões nessa região, como a do radical $\mathrm{OH}^{*}$, é utilizado um intensificador de imagem HAMAMATSU capaz de converter essa emissão para a faixa do visível. Além disso, o vidro comum de borossilicato é opaco ao ultravioleta portanto para a observação do $\mathrm{OH}^{*}$ foi utilizada um conjunto especial de lentes de quartzo com distância focal de $100 \mathrm{~mm}$ no lugar das lentes convencionais de distância focal $60 \mathrm{~mm}$ utilizadas em outros testes. A maior dificuldade de se trabalhar com esse conjunto de lentes é que eles produzem maiores distorções do que o conjunto convencional devido aos seus aspectos construtivos. Dessa forma, é importante realizar a correção das imagens no tratamento de dados.

Todos esses elementos, os queimadores, câmeras, intensificador de imagem, entre outros equipamentos foram montados em uma estrutura com perfis de alumínio, os quais permitem fixar estaticamente os equipamentos e servem como uma sólida referência para o posicionamento dos experimentos. Além disso, foi usado um posicionador de três dimensões automático (traverso atuado) que permite posicionamentos com precisão 


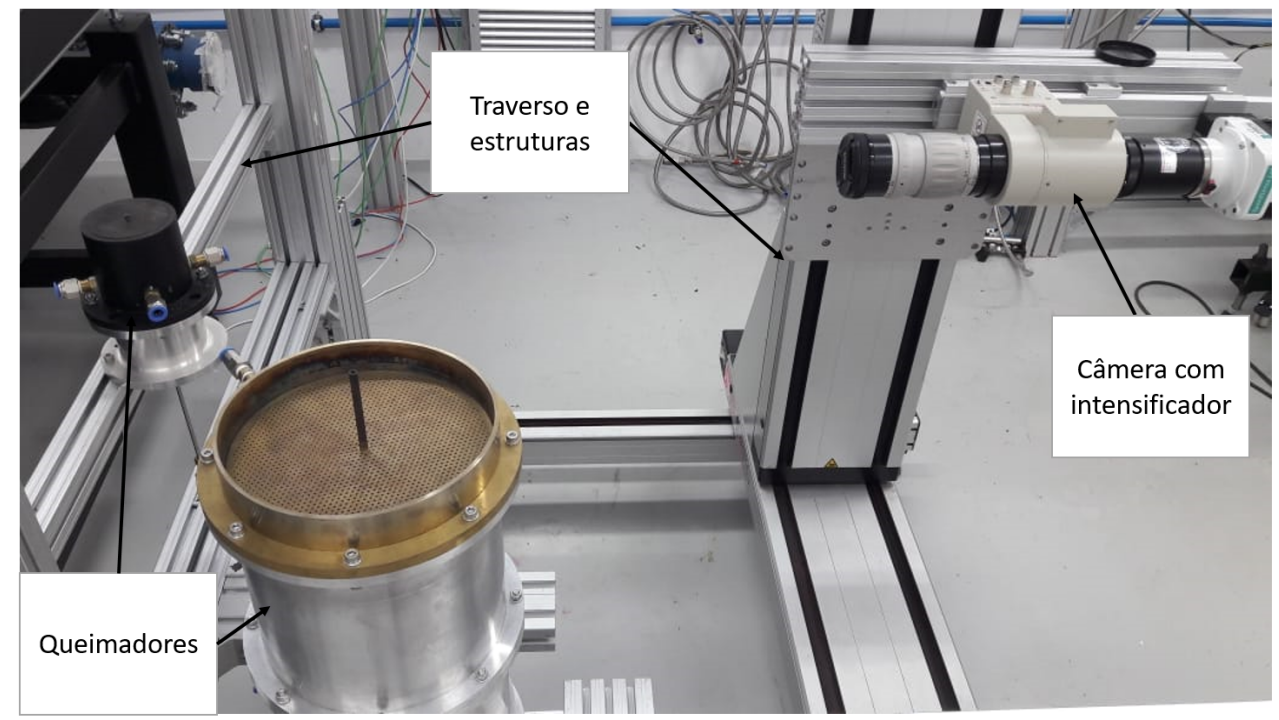

Figura 20 - Bancada experimental com dois queimadores posicionados

de décimos de milímetro. Nesse foi fixada a câmera principal que capta as imagens de quimioluminescência total e filtrada. A figura 20 mostra a bancada experimental utilizada com dois queimadores presos. Esta configuração permite prender múltiplos experimentos rigidamente, assim pode-se trocar de teste rapidamente. Isso foi essencial, pois muitos testes precisaram serem refeitos conforme os dados eram coletados e novas configurações de interesse eram propostas. Dessa forma, ao invés dos experimentos ocorrerem em uma sequência, foram feitas diversas interações com testes sendo repetidos com condições ligeiramente diferentes.

\subsection{Quimioluminescência}

Durante a combustão, a energia liberada pela reação excita alguns radicais que acabam por mudar de estado eletrônico e nesse processo emitem um fóton(GAYDON, 2012). Tal efeito é conhecido por quimioluminescência e pode ser observado a olho nu como parte da luz emitida pela chama. Como o tempo de vida do radical excitado é pequeno sua emissão ocorre na região da excitação, ou seja, na zona de reação. Dessa maneira, a emissão demarca espacialmente o local da reação química e sua intensidade se correlaciona com o calor liberado na combustão(GAYDON, 2012). Dentre os inúmeros radicais produzidos, dois se destacam neste processo: o radical $O H^{*}$ e o $C H^{*}$.

$\mathrm{Na}$ literatura, a reação 3.2 é considerada a principal fonte de radicais $O H^{*}$ ativados e seu tempo de vida é da ordem de grandeza de $1 \mu s$ (GAYDON, 2012). Por causa deste diminuto tempo de vida, a concentração do radical ativado está praticamente em equilíbrio químico, assim as concentrações dos outros componentes da reação podem ser estimadas via equilíbrio, caso a temperatura seja conhecida. Relações empíricas entre a liberação de calor e quimioluminescência foram levantadas para chamas pré-misturadas de gás natural 
e ar (HARDALUPAS; ORAIN, 2004), a dificuldade dessa técnica está na calibração do sinal luminoso.

Foram feitas medições de quimioluminescência de $O H^{*}$ e $C H^{*}$ para uma chama de difusão na configuração de contra-corrente(figura 6a) para metano e ar enriquecido(LEO et al., 2007). Esses dados corroboram com a relação entre a emissão de calor e a concentração dos radicais. Para definir a zona de reação o radical $O H^{*}$ é um melhor marcador do que o radical $C H^{*}$, pois o seu pico de concentração está mais próximo da região da estequiometria, enquanto o $C H^{*}$ tende para região rica(LEO et al., 2007; PANOUTSOS; HARDALUPAS; TAYLOR, 2009). A relação entre esses radicais também pode ser utilizada para medir a liberação de energia e a razão de equivalência nas proximidades da zona de reação(HARDALUPAS; ORAIN, 2004).

$$
\mathrm{CH}^{*}+\mathrm{O}_{2} \leftrightarrow \mathrm{CO}+\mathrm{OH}^{*}
$$

Em um trabalho mais recente(GUIBERTI; DUROX; SCHULLER, 2017), foram avaliadas as emissões dos dois radicais $\left(O H^{*}\right.$ e $\left.C H^{*}\right)$ e do dióxido de carbono em uma chama laminar pré-misturada de metano e ar. Devido à sua alta concentração comparada com as dos radicais, o $\mathrm{CO}_{2}$ acaba por criar uma emissão de fundo que foi subtraída dos outros sinais. Esta interferência foi pouco relevante na medição do radical hidroxila, mas foi representativa no radical $C H^{*}$. O objetivo desse estudo foi avaliar os efeitos sobre a combustão da diluição do combustível com dióxido de carbono e nitrogênio simulando as condições do biogás. O estudo avaliou a relação entre a quimioluminescência do radical hidroxila e do dióxido de carbono e mostrou que poderia ser utilizada como parâmetro para inferir a diluição total por $\mathrm{CO}_{2}$.

Para realizar as medições, a luz emitida pela chama passa por um filtro óptico na frequência de emissão do radical, de forma que apenas a emissão do radical seja vista. Em seguida, a luz passa por um intensificador de imagem, a fim de amplificar o sinal até serem captadas por uma câmera de alta velocidade. A emissão do radical $O H^{*}$ se concentra no comprimento de onda $307 \mathrm{~nm}$ enquanto a do radical $C H^{*}$ esta na região dos $430 \mathrm{~nm}$.

\subsection{Processamento de imagem}

Todas as imagens adquiridas durante os experimentos necessitaram de um pós processamento para reduzir ruídos, corrigir distorções e para determinar estruturas geométricas. Dentre todos os experimentos, o número de imagens brutas adquiridas variou entre dois mil até seis mil imagens dependendo do nível de ruído, enquanto a frequência de aquisição variou entre $500 \mathrm{~Hz}$ até $2000 \mathrm{~Hz}$. As maiores taxas de aquisição e a maior quantidade de imagens coletada foram utilizadas para as chamas turbulentas. Como em todos os casos o maior interesse residia no comportamento médio das chamas, a primeira 
etapa em todas as medições foi realizar uma média com todas as imagens adquiridas. Tal abordagem foi essencial nos dados adquiridos com o intensificador de imagem, pois foi observado que as imagens obtidas eram muito ruidosas, em especial, estavam contaminadas com um tipo de ruído conhecido por salt-and-pepper (GONZALEZ; WOODS, 2009). Esse ruído permanecia mesmo quando o objeto observado estava totalmente estático, assim é provável que ele ocorra devido a alguma característica construtiva do intensificador. Uma hipótese plausível, mas que não foi explorada, é que devido à baixa intensidade do sinal o ganho utilizado no equipamento foi muito alto, de forma que qualquer luminosidade adicional que passasse por uma saturação no filtro, causaria um clarão de luz pontual. Todavia, fazendo a média das imagens, o ruído foi reduzido, permitindo as análise subsequentes. Como exemplo, a figura $21 \mathrm{a}$ mostra a imagem instantânea da emissão do $\mathrm{OH}^{*}$ adquirida pelo conjunto óptico (filtro, lentes, intensificador e câmera) em uma chama turbulenta, enquanto a figura $21 \mathrm{~b}$ mostra a média, fica nítido a redução do ruído devido ao processo de média.

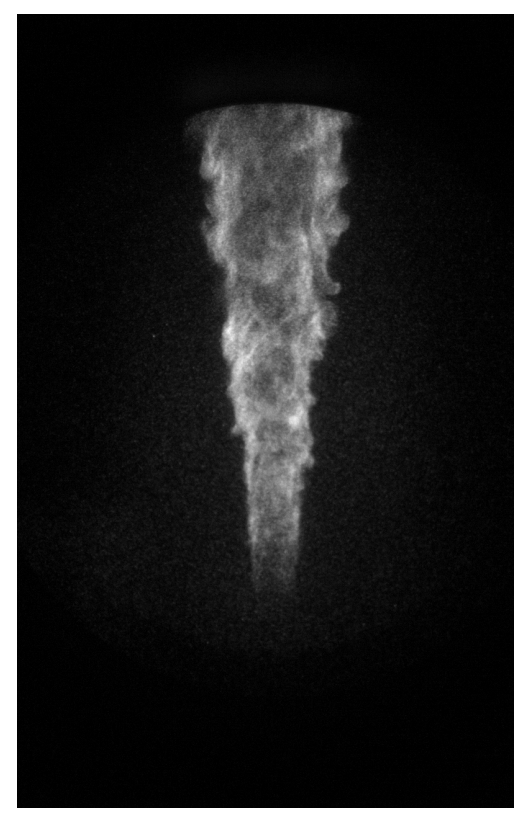

(a) Emissão captada pelo conjunto óptico

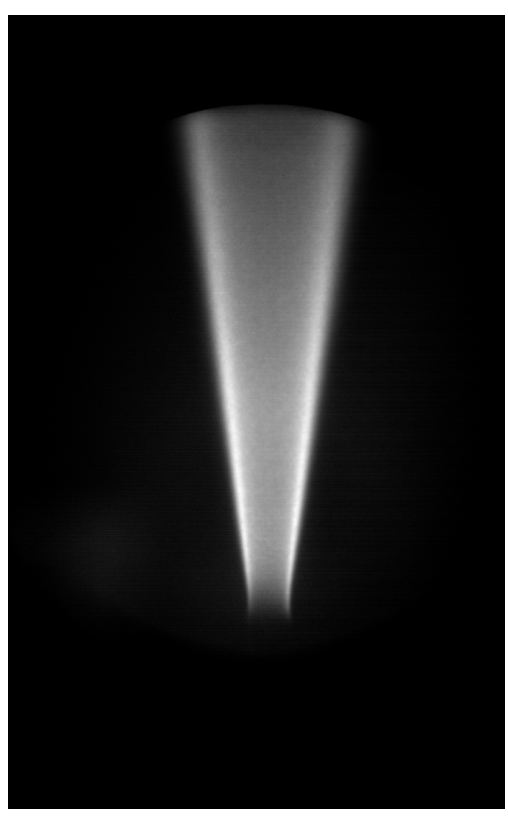

(b) Média das imagens

Figura 21 - Emissão luminosa do $\mathrm{OH}^{\star}$

Em seguida as imagens foram processadas para reduzir a distorção causada pelas lentes, filtros e intensificador. O objetivo dessa etapa é fazer com que as imagens se aproximem de uma projeção ortogonal para que possam ser feitas inferências geométricas corretamente.

Afim de corrigir as imagens foi feito um alvo composto de pontos de $0,5 \mathrm{~mm}$ de diâmetro com espaçamento entre centros de $3 \mathrm{~mm}$. Dessa forma, ao se fotografar essa imagem cria-se uma correlação entre o espaço de imagens e o espaço físico que permite não só a correção da distorção, mas correlaciona o espaço de imagem com o espaço físico produzindo uma calibração espacial. Utilizou-se uma rotina no software MATLAB que 
produziu uma matriz de transformação linear a partir das imagens do calibrador e da informação do formato real do calibrador. Por sua vez, quando essa matriz é aplicada, cada ponto da imagem é deslocado de maneira a recuperar o formato real. O resultado desse processamento é nítido quando se compara a figura 22a, que mostra a imagem original captada através do conjunto óptico, em relação a figura 22b, a qual mostra o calibrador praticamente sem distorção. Uma limitação dessa abordagem é que nas laterais a qualidade da correção, é menor e como a imagem é reduzida pela correção surge uma faixa preta nas bordas. Entretanto, isso não afeta as medições, pois todas as chamas foram posicionadas no centro do conjunto óptico, deixando uma margem entre a borda da imagem a chama. A partir da matriz obtida com o calibrador, todas as imagens adquiridas com uma certa montagem experimental são corrigidas, caso haja movimentação das câmera ou do queimador é realizada uma nova calibração, adquirindo uma nova imagem do calibrador e consequentemente uma nova matriz de correção.

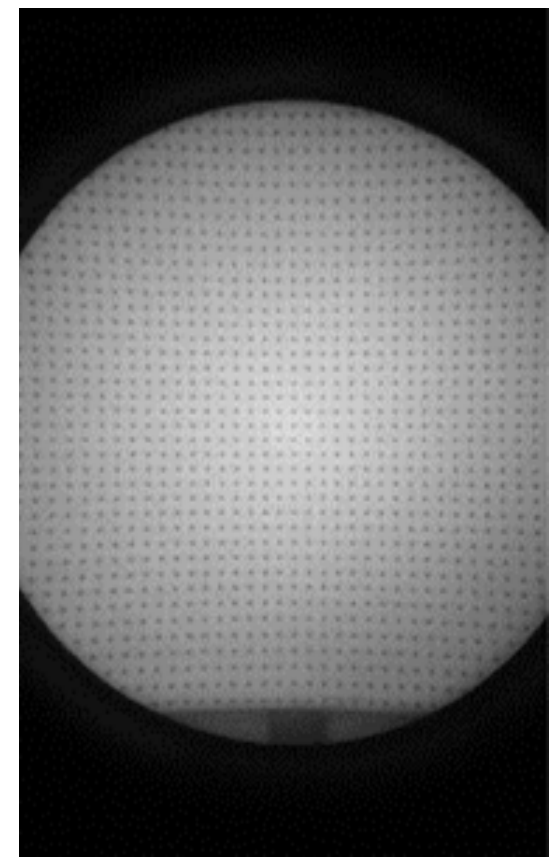

(a) Imagem original do calibrador

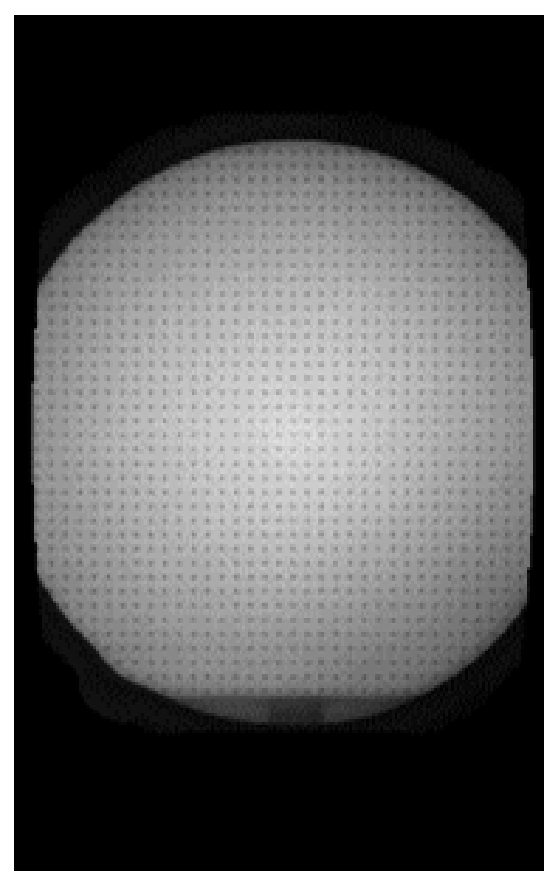

(b) Imagem corrigida

Figura 22 - Imagens para o procedimento de correção das distorções do conjunto óptico

Em alguns dos experimentos realizados é necessário identificar linhas retas nos contornos das chamas. Para evitar a arbitrariedade de se determinar manualmente qual seria a tangente de uma chama cônica, foi adotada a transformada de Hough (BALLARD, 1981). Essa transformada é uma das mais antigas técnicas de visão computacional, sendo patenteada em 1962, além de uma das mais utilizadas e citadas (KAUFMANN, 2004). Para aplicar essa transformada a imagem é primeiro binarizada utilizando o método global de Otsu (OTSU, 1979), em seguida o algorítimo testa todas as possíveis linhas existentes na imagem e dá uma nota para a qualidade de cada linha, considerando os pixeis que ela delimita. A parte mais complexa desse algorítimo é o acumulador que determina a nota 
de cada linha, esse é capaz de trabalhar com o contraste da imagem para determinar qual linha deveria ter a maior nota. A partir disso é construído um espaço de estados de Hough com as coordenadas polares das retas e com os valores das notas. Os picos encontrados nessa matriz delimitam as retas mais prováveis. As figuras 23a e 23b mostram um exemplo do resultado desse processamento de dados utilizando a transformada de Hough, calculada utilizando as rotinas disponíveis no MATLAB, percebe-se que há duas regiões de pico que correspondem as duas linhas visíveis nas imagens.

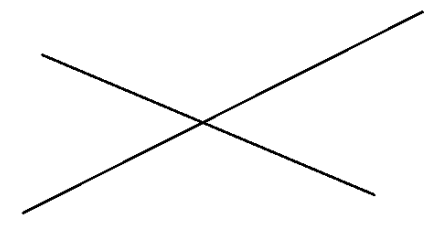

(a) Imagem original

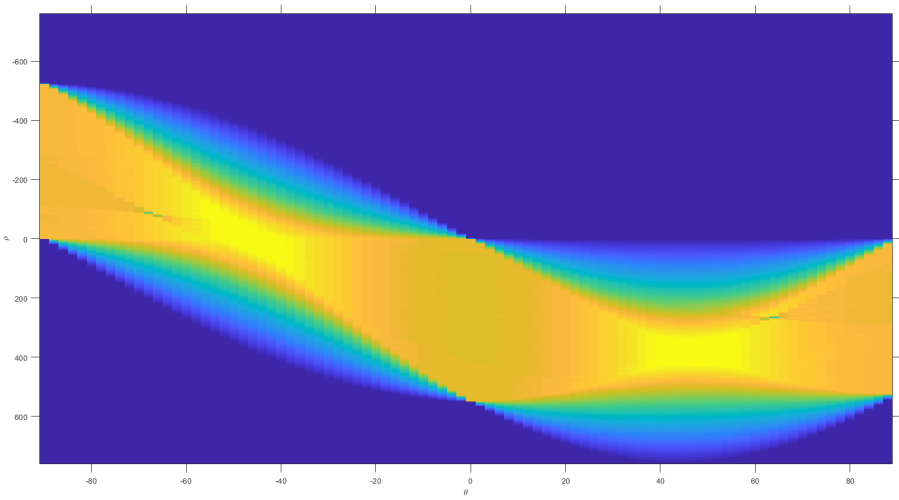

(b) Espaço de estados

Figura 23 - Exemplo da transformada de Hough

Neste trabalho, essa transformada foi utilizada para detectar a linhas que compõem o cone da chama nos experimentos para medir a velocidade laminar. Outra vantagem dessa abordagem é permitir a analise automática de dezenas de imagens.

A figura 24 mostra um exemplo de chama cônica na qual foi aplicada a transformada produzindo as retas do cone. Essas retas são construídas para otimizarem o cone na sua parte média, onde o erro induzido por distorções no formato do cone é menor. Em seguida, o ângulo formado entre essas duas retas é calculado para ser posteriormente usado no cálculo da velocidade de chama laminar.

\subsection{Anemômetro de fio quente}

$\mathrm{Na}$ anemometria por fio quente, uma sonda composta por um fio muito fino é colocada no escoamento e é aplicada uma corrente sobre ela. Conforme o gás passa pelo fio ocorre transferência de calor proporcional a temperatura que se reflete na mudança da tensão aplicada na sonda. Para correlacionar essa mudança de tensão com a velocidade é necessária uma etapa de calibração. Isso foi feito através de um calibrador automático disponível no laboratório de combustão que cria um escoamento de velocidade conhecida. Em seguida, o sistema de aquisição mede a tensão em cada uma das velocidade 


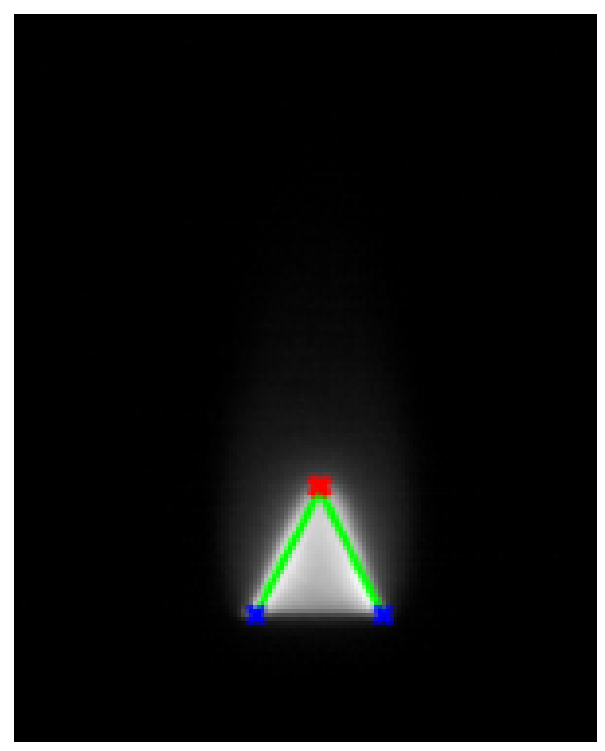

Figura 24 - Chama cônica com as linhas obtidas pelo transformada de Hough

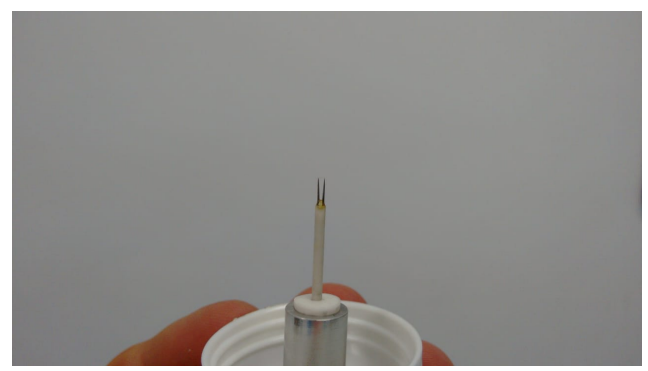

Figura 25 - Imagem da sonda utilizada

configuradas pelo calibrador. Finalmente, um polinômio é ajustado para todos os pontos aquistados e a partir de seus coeficientes é feita a conversão da tensão em velocidade.

Em todos os testes com o anemômetro (CTA-Constant Temperature Anemometer) foi utilizada a sonda unidimensional 55P11 (figure 25). Com ela é possível medir apenas a magnitude da velocidade do gás que passa pela sonda. Como os escoamentos a serem medidos apresentam apenas uma componente dominante, a falta dos componentes cartesianas da velocidade não irá afetar a análise proposta. Por fim, para reduzir a complexidade do experimento e do processo de calibração só será utilizada a sonda unidimensional.

Antes de iniciar as primeiras observações da oxi-combustão no primeiro queimador construído(queimador Yale) foi avaliado a homogeneidade do seu escoamento secundário. Isso é importante, pois uma assimetria nesse fluxo pode afetar a observação da chama. Nesse estudo foi adotada a técnica anemometria de fio quente que é uma medição pontual velocidade. Como o objetivo desse breve estudo é simplesmente avaliar a homogeneidade do escoamento que deve ter apenas uma componente dominante foi utilizada a sonda com apenas um fio que permite medir apenas a magnitude da velocidade. No experimento foi utilizado ar em ambas as saídas de gás do queimador, já que a sonda utilizada não pode ser operada próxima a uma fonte de calor como a chama. Assim, esse foi um teste frio com 
o queimador desligado utilizando ar em todas as saídas. As vazões adotadas para os dois escoamentos estão explicitadas na tabela 2. Com essa vazão volumétrica, a velocidade média esperada no escoamento secundário é de $0,419 \mathrm{~m} / \mathrm{s}$ com incerteza de $0,5 \mathrm{~m} / \mathrm{s}$ devido à precisão do regulador.

Tabela 2 - Vazão de ar utilizada na anemometria

\begin{tabular}{|c|c|}
\hline Escoamento secundário & $100 \mathrm{~L} / \mathrm{min} \pm 5 \mathrm{~L} / \mathrm{min}$ \\
\hline Tubo central & $0,3 \mathrm{~L} / \mathrm{min} \pm 0,05 \mathrm{~L} / \mathrm{min}$ \\
\hline
\end{tabular}

A sonda foi calibrada no intervalo de $0,2-2 \mathrm{~m} / \mathrm{s}$ utilizando 18 pontos aquistados no calibrador automático, depois um polinômio de quarta ordem foi ajustado para determinar os coeficientes da conversão de tensão em velocidade. A frequência de aquisição utilizada foi de $4 \mathrm{kHz}$ e para cada ponto foram tomadas 20 mil medições. A sonda foi fixada na extremidade de um traverso manual milimetrado que permitiu que ela fosse deslocada radialmente ao longo do queimador. Esse traverso é mostrado nas figuras $26 \mathrm{a}$ e 26b, acoplado a um suporte em alumínio, construído pelo autor, para fixar o traverso na mesma estrutura, a qual o queimador está preso. Para centralizar o suporte no tubo de injeção de combustível, um pino guia foi fixado no interior do injetor de combustível. Em seguida, os parafusos que seguram o suporte foram ajustados de forma que prendessem o pino guia sem que ele fletisse. Depois, apenas o último parafuso foi solto, o pino retirado e a haste com a sonda na ponta foi instalada, permanecendo a $10 \mathrm{~mm}$ de altura em relação à colmeia superior, garantindo a centralização da sonda.

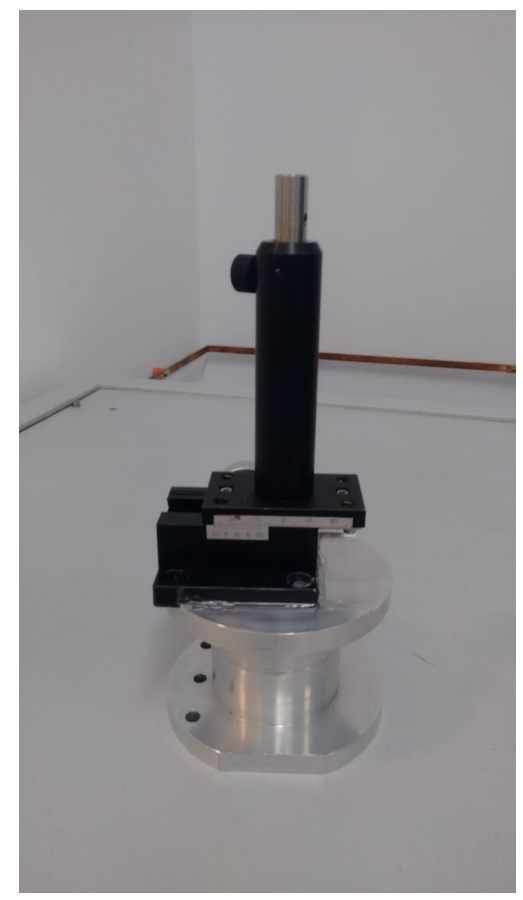

(a) Traverso manual

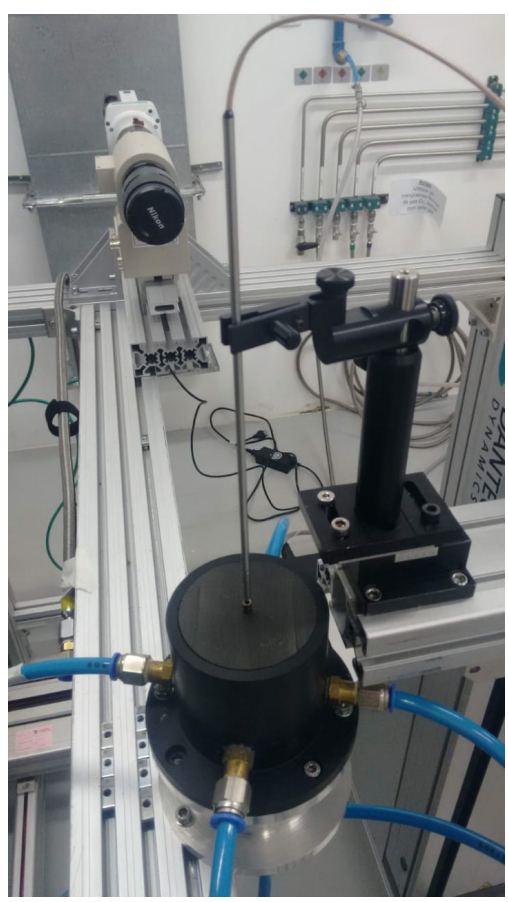

(b) Equipamento montado no queimador

Figura 26 - Aparato experimental utilizado 
A variável independente estudada é o preenchimento do volume entre as colmeias de hasteloy com as esferas de vidro de $3 \mathrm{~mm}$ de diâmetro. Na primeira medição, o espaço foi completamente preenchido pelas esferas de vidro. Então, foram feita medidas ao longo do raio do queimador, deslocando a sonda um milimetro para cada nova medição. Em seguida, o mesmo procedimento foi repetido com apenas metade do volume preenchido com esferas de vidro. As velocidades médias aquistadas são mostradas no gráfico 27, é nítido que no caso com o volume todo ocupado por bolinhas de vidro, o perfil de velocidade é mais heterogêneo do que o caso com o volume preenchido até a metade.As incertezas do anemômetro de fio quente com a correção de temperatura são da ordem de $2 \%$ do valor da medida, dessa forma os valores são muito pequenos para serem visíveis no gráfico 27. A hipótese é que as esferas obstruem a passagem do ar quando estão em contato com a colmeia superior, além disso o gás cria caminhos preferenciais dentro da estrutura das esferas. Assim, para se obter um resultado mais homogêneo é necessário um pequeno pleno para acomodar essas assimetrias e afastar as esferas do honeycomb superior.

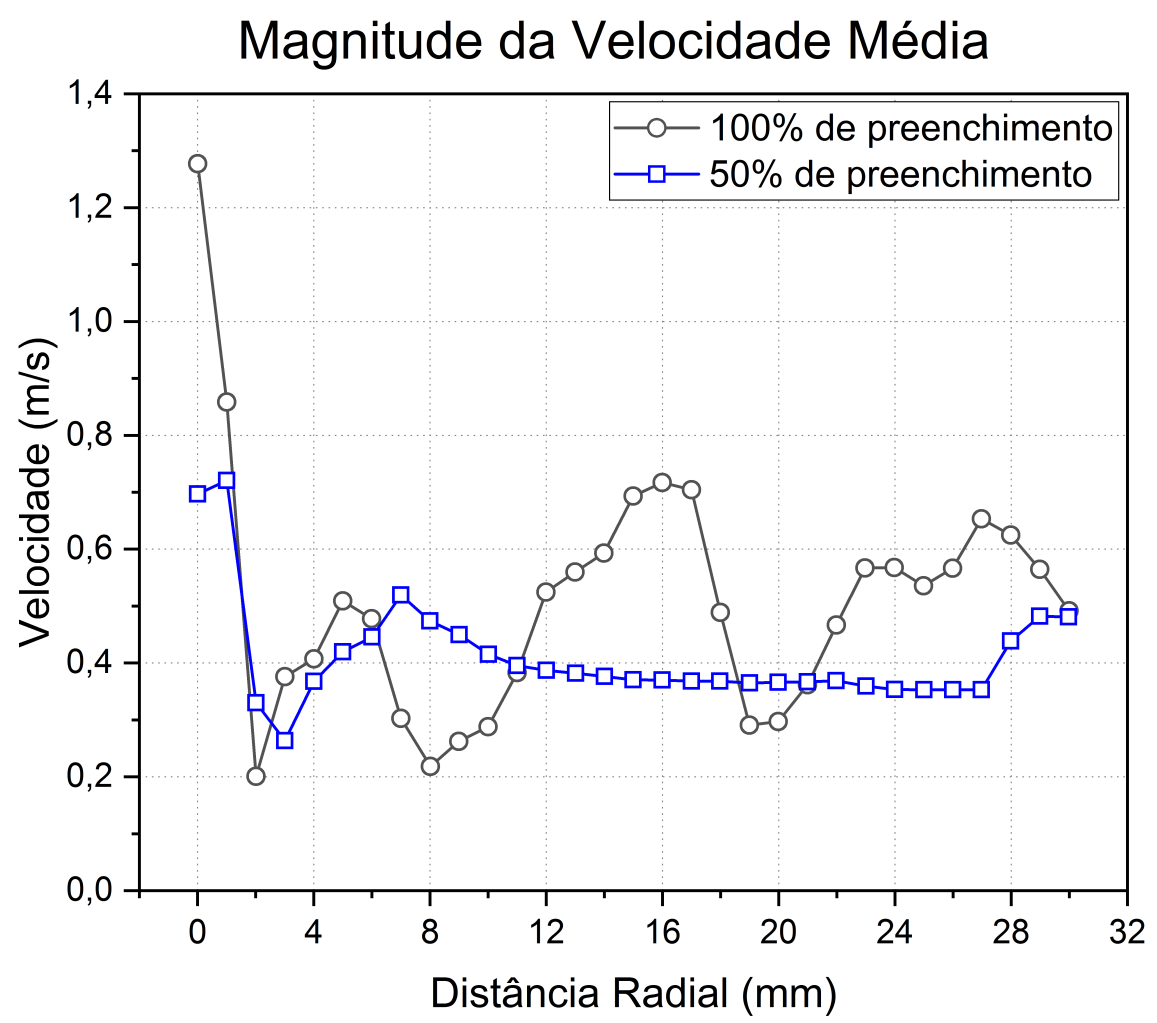

Figura 27 - velocidade média ao longo do raio nos dois experimentos realizados

Também foi calculada a intensidade turbulenta de cada ponto medido a partir do desvio padrão, resultando no gráfico 28. Devido a proximidade da sonda com o honeycomb existe uma flutuação turbulenta ao longo de todo o escoamento secundário. Também variações mais intensas no raio de 2 até 10 milímetros, isso ocorre pois é nessa região onde há os maiores gradientes de velocidade. Esse é um efeito construtivo, pois nessa região 
se encontra a espessura do tubo central o que gera uma pequena zona de recirculação que produz energia cinética turbulenta. Entretanto, essas pequenas flutuações não são capazes de transicionar a chama central de forma que ela permanece laminar em todos os testes realizados a posteriori.

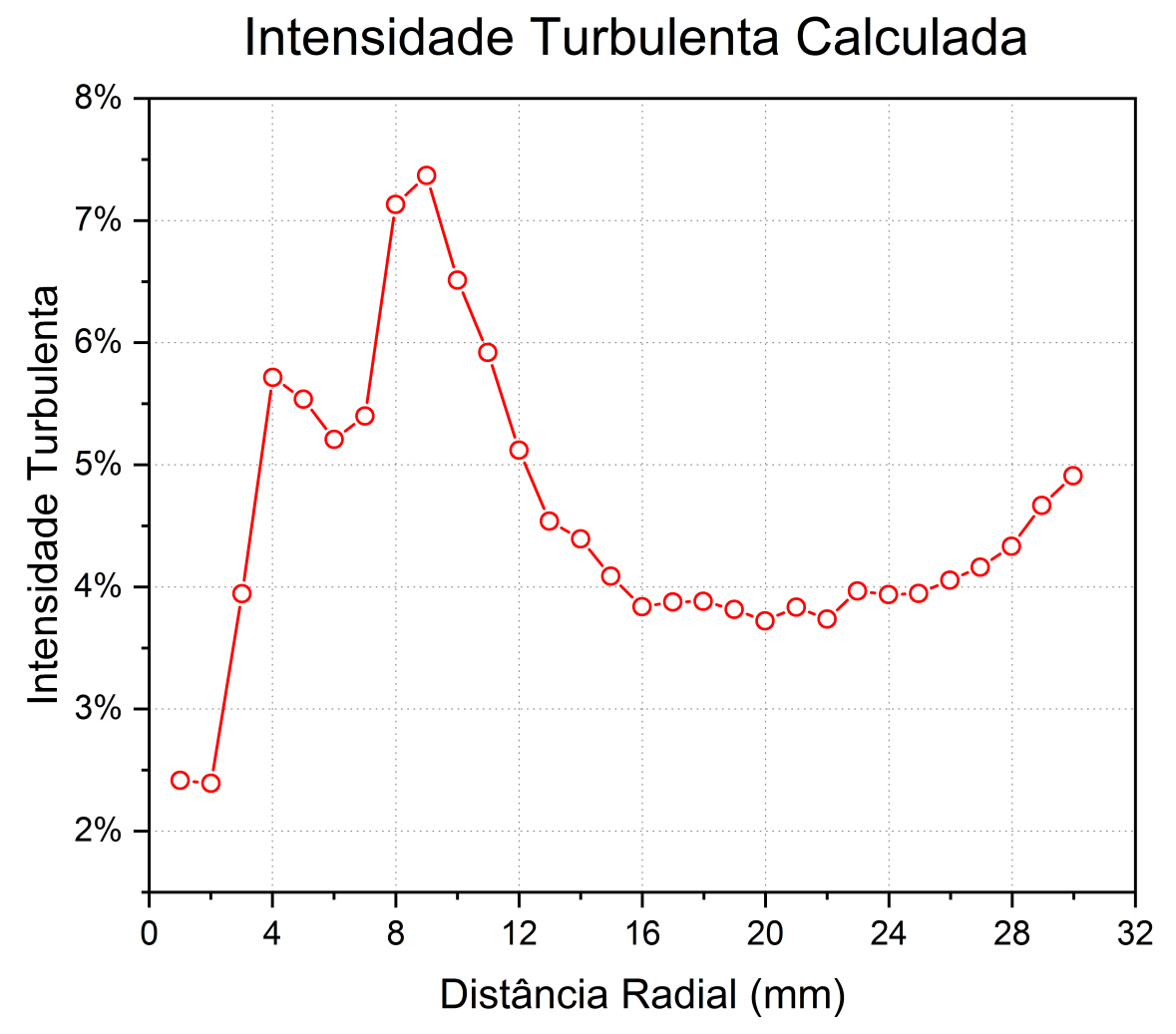

Figura 28 - intensidade turbulenta no queimador

\subsection{Incertezas}

A determinação das incertezas é uma etapa indispensável para qualquer medida, haja visto que toda medida consiste em determinar um intervalo no qual o valor real esteja contido. Quanto menor as incertezas, menor será esse intervalo, de forma que no limite obtêm-se o valor real. Entretanto, na prática, existe um limite para a precisão que se pode obter com uma determinada montagem experimental e técnica de inferência. Por isso, todo valor medido deve ser acompanhado pelo sua respectiva incerteza.

Para determinar as incertezas nas medidas realizadas neste trabalho, as fontes de erros foram dividas em duas: as devidas as limitações dos instrumentos, e as devidas a montagem física do experimento. O primeiro caso, corresponde às limitações de resolução dos dispositivos utilizados para controle dos parâmetros experimentais (como os rotâmetros) e dos instrumentos de medição. Em alguns dispositivos isso foi facilmente determinado pelas suas características construtivas ou informações do fabricante, como 
no caso dos rotâmetros no qual a resolução é a metade da menor medida. Assim, para o rotâmetro de $0-100 \mathrm{~L} / \mathrm{min}$ e $0-50 \mathrm{~L} / \mathrm{min}$ o valor foi de $5 \mathrm{~L} / \mathrm{min}$, para o de $0-5 \mathrm{~L} / \mathrm{min}$ foi de $0,5 \mathrm{~L} / \mathrm{min}$ e para o de $0-1 \mathrm{~L} / \mathrm{min}$ foi de $0,05 \mathrm{~L} / \mathrm{min}$. Isso também foi simples no caso do anemômetro, pois o fabricante assegura um erro da ordem de $2 \%$ quando aplicada a correção de temperatura, que foi o caso. Entretanto, o erro na aquisição das imagens é mais difícil de ser estimado, com isso foi adotada uma abordagem de minimização. Essa consistiu em: comparar apenas resultados tomados para uma mesma configuração óptica, isto é, apenas quando os dados são coletados na mesma secção experimental com todos os parâmetros de aquisição iguais (número de imagens, taxa de aquisição, ganho do intensificador) as imagens são comparáveis, e utilizar imagens de calibração, essa já descrita em seção anterior. Dessa forma, minora-se os desvios que a inferência óptica possa causar. Em seguida, os erros de posicionamento da montagem física do experimento também não foram estimados, mas se trabalhou para que fossem reduzidos até que não se pudesse mais medi-los com os medidores do laboratório (réguas, esquadros e paquímetros). Assim, os desvios ocasionados por essas fontes acabam por ser muito inferior ao erro induzido pelas fontes conhecidas, quando isso ocorre, e não se observa alteração significativa nos resultados com tentativas de se melhorar o posicionamento por exemplo, assume-se que esse erro é depressível. Entretanto, essa é uma abordagem exaustiva que consome muito tempo até que cada montagem esteja pronta para o experimento, e que necessita ser repetida caso haja movimentação das estruturas ou troca do conjunto óptico.

Por fim, após a aquisição dos dados ocorre o pós-processamento, esse também interfere nas medições e pode ampliar os erros. Entretanto, a determinação do efeito do erro sobre essas operações é muito complexo, inclusive, porque operações de filtragem de imagem muitas vezes reduzem a quantidade de informação. Assim, falar de erro em processamento de imagem é difícil e cada caso deve ser tratado com uma abordagem diferente. Neste trabalho foi proposta uma abordagem para estimar o erro induzido na transformada de Hough para a determinação dos contornos das chamas laminares. A ideia se baseia nos algorítimos para se estimar o erro em correlação cruzada a partir da comparação do pico principal com o pico secundário. Visto que , a transformada de Hough também produz uma distribuição em um espaço de estados com valores máximos (picos), algo análogo ao caso da correlação, a proposta é comparar o ângulo do cone da chama calculado com os maiores picos de cada lado do cone com o ângulo calculado utilizando os picos em segundo lugar. Com isso, extrair uma estimativa da incerteza dessa medição do ângulo com as imagens binariadas e a transformada de Hough. Dessa forma, a incerteza total da velocidade de chama laminar pode ser determinada combinando a incerteza no valor da vazão com a incerteza na medida do ângulo do cone. 


\section{Resultados}

A primeira etapa da investigação envolveu a observação macroscópica das mudanças na oxi-combustão em relação à combustão convencional. Para tanto, foi utilizada chamas laminares no queimador Yale. Nessa fase foram constatadas as reduções de estabilidade e intensidade das reações previstas pela literatura. Em seguida, os estudos prosseguiram comparando o efeito da diluição com dióxido de carbono com a diluição com nitrogênio e argônio. Essa abordagem foi utilizada, pois permite isolar algumas variáveis durantes os experimentos, por exemplo, ao utilizar o argônio pode-se avaliar o comportamento de um diluente completamente inerte, porém com uma capacidade térmica menor que a do nitrogênio presente no ar. Dessa forma, se a maior capacidade térmica do dióxido de carbono fosse a principal responsável pela mudança de comportamento, deveria-se observar um comportamento semelhante ao dos outros gases inertes (nitrogênio e argônio). Esta comparação entre diferentes diluentes foi realizada no queimador Yale e no queimador cônico. Por fim, uma chama suspensa de metano foi diluída com dióxido de carbono para avaliar o impacto desse gás em uma combustão turbulenta.

\subsection{Queimador Yale}

A primeira sequência de ensaios realizada para observar as alterações na oxicombustão utilizou chamas de difusão de metano. Esses ensaios utilizaram a técnica da quimioluminescência com um filtro óptico passa-banda com banda de 390-440 nm. Nessa região ocorre a emissão luminosa do radical químico $\mathrm{CH}$ (emite na faixa do $430 \mathrm{~nm}$ ) entretanto a largura do filtro também permite que outras emissões luminosas interfiram no sinal. Ainda assim, esse filtro foi utilizado, pois permite que a câmera opera sem o uso do intensificador de imagem, já que a luz que passa através do filtro ainda se encontro na região do espectro captável pelo sensor CMOS da câmera. Essa observação de quimioluminescência natural serve como um estudo qualitativo do comportamento da chama, comparando o caso atmosférico com o caso do ambiente com oxidante composto apenas por oxigênio e dióxido de carbono.

O ensaio de referência foi feito com uma chama de difusão de metano no tubo central, enquanto no escoamento secundário foi utilizado ar. Para os testes de oxi-combustão o queimador foi isolado do ar atmosférico por um tubo de quartzo com $70 \mathrm{~mm}$ de diâmetro que foi preso à parede externa do queimador.

A figura 29a mostra uma chama de metano convencional enquanto na imagem $29 \mathrm{~b}$ temos uma chama de oxi-combustão em uma atmosfera controlada composta apenas por dióxido de carbono e oxigênio. No caso da figura $29 \mathrm{~b}$ a chama ficou suspensa para as 
condições testadas, entretanto essa condição foi extremamente instável permanecendo nessa situação por poucos segundos.

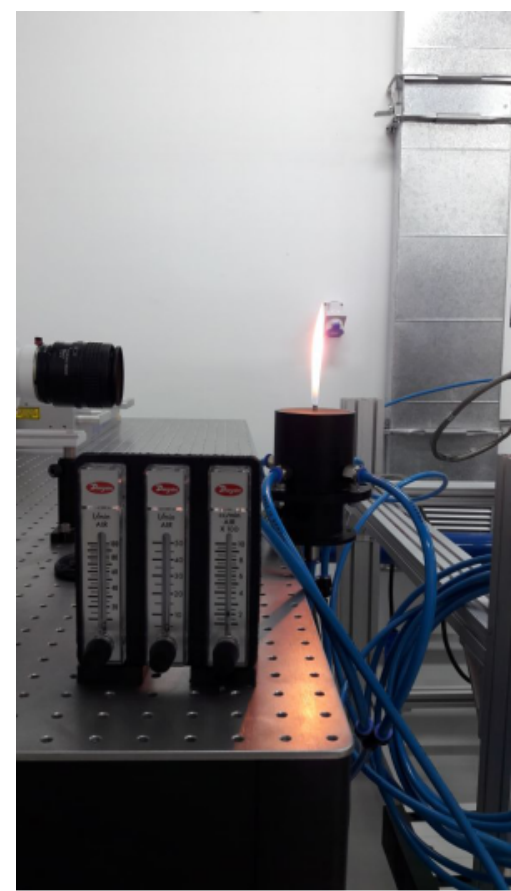

(a) Chama de difusão no ar atmosférico

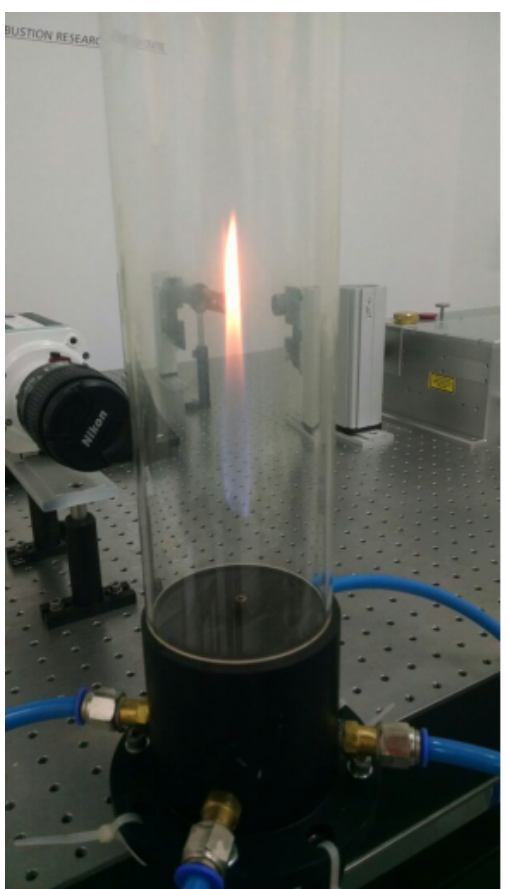

(b) Chama isolada em atmosfera controlada

Figura 29 - Testes com chama no queimador Yale

A presença do quartzo pode acarretar distorções na imagem, podendo prejudicar a visualização da chama. Para compensar esses efeitos, um alvo xadrez com o tamanho aproximado da chama foi posicionado no centro do queimador e imagens com e sem o quartzo foram feitas para avaliar a distorção(figura 30 .

Percebe-se que na região de interesse demarcada pelo calibrador a distorção é pequena, ainda assim essas distorções foram corrigidas nas imagens finais utilizando uma matriz de transformação linear calculada a partir dos pontos no xadrez.

Para os testes foram utilizadas as vazões de combustível e oxidante indicadas na tabela 3. Para a oxi-combustão foram utilizadas as composições do oxidante listadas na tabela 4. As incertezas nas medições são devidas aos reguladores utilizados, para a vazão do combustível há uma incerteza de $0,025 \mathrm{l} / \mathrm{min}$, enquanto na vazão do oxidante essa incerteza é de $5 \mathrm{l} / \mathrm{min}$. Dessa forma, na concentração dos gases no oxidante há uma incerteza de $2,5 \%$.

Tabela 3 - Vazões utilizadas no queimador Yale

\begin{tabular}{|c|c|}
\hline Vazão de combustível & $0,35 \mathrm{~L} / \mathrm{min} \pm 0,05 \mathrm{~L} / \mathrm{min}$ \\
\hline Vazão de oxidante & $100 \mathrm{l} / \mathrm{min} \pm 5 \mathrm{~L} / \mathrm{min}$ \\
\hline
\end{tabular}

A figura 31 mostra emissão luminosa na faixa 400-440nm da chama de difusão de metano no ar, enquanto a sequência de imagens 32 mostra as chamas de difusão 


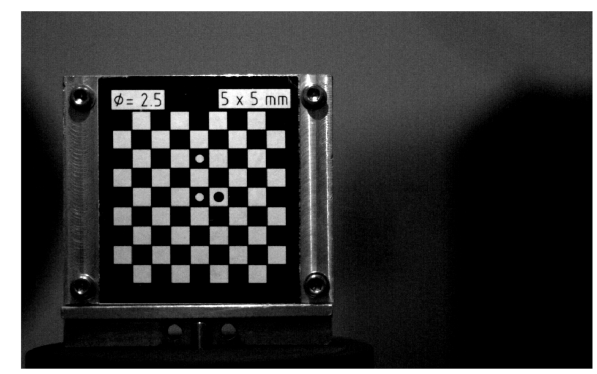

(a) Alvo sem a janela

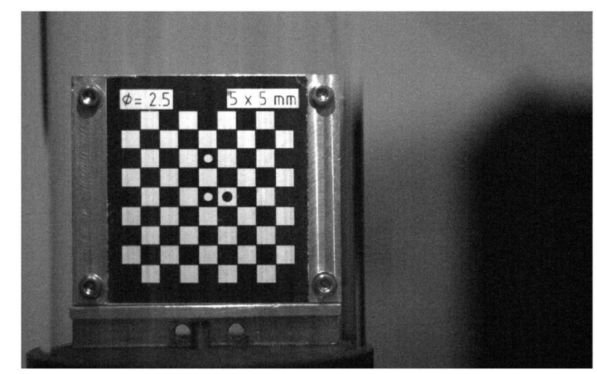

(b) Alvo no interior do quartzo

Figura 30 - Imagens do calibrador

Tabela 4 - Composições do oxidante no queimador Yale

\begin{tabular}{c|c} 
Fração molar de oxigênio & Fração molar de dióxido de carbono \\
\hline $50 \% \pm 2,5 \%$ & $50 \% \pm 2,5 \%$ \\
$40 \% \pm 2,5 \%$ & $60 \% \pm 2,5 \%$ \\
$35 \% \pm 2,5 \%$ & $65 \% \pm 2,5 \%$ \\
$30 \% \pm 2,5 \%$ & $70 \% \pm 2,5 \%$
\end{tabular}

na atmosfera de oxigênio e dióxido de carbono. A primeira observação é que para uma concentração de oxigênio menor do que 35\%, a chama não se manteve estável e se extinguiu. Comparando, qualitativamente as emissões quimioluminescentes, percebe-se que as chamas na oxi-combustão foram sempre menores do que aquela em ar, isso mesmo nas proximidades da extinção. Outra observação é a aparente diminuição da intensidade luminosa da reação mesmo com a potência da chama sendo constante. Isso poderia decorrer de uma mudança na distribuição da luminosidade ao longo dos diversos comprimentos de onda, de forma que menos energia estaria presente na faixa espectral observada. Entretanto, também poderia ser uma consequência de mudanças no processo de combustão induzidos pelo dióxido de carbono. As principais hipóteses discutidas na literatura são alterações nas reações químicas, pois o dióxido de carbono é um produto delas, dessa forma, ele deslocaria os potenciais químicos desacelerando a reação; redução da temperatura, já que o dióxido de carbono possui uma maior capacidade térmica e diferenças nos coeficientes de difusão.

A partir desses resultados foi levantada a hipótese de que um diluente completa- 


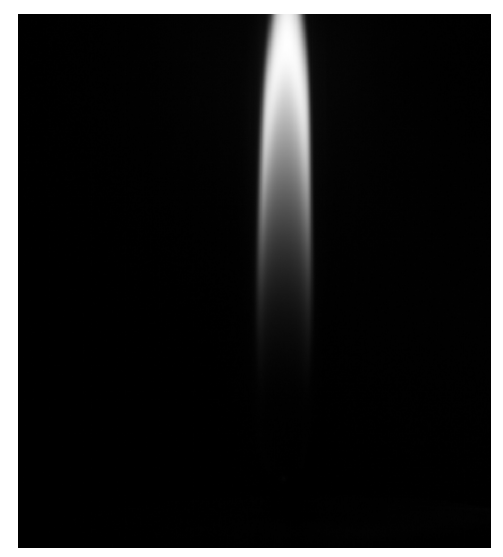

Figura 31 - Chama de referência no ar
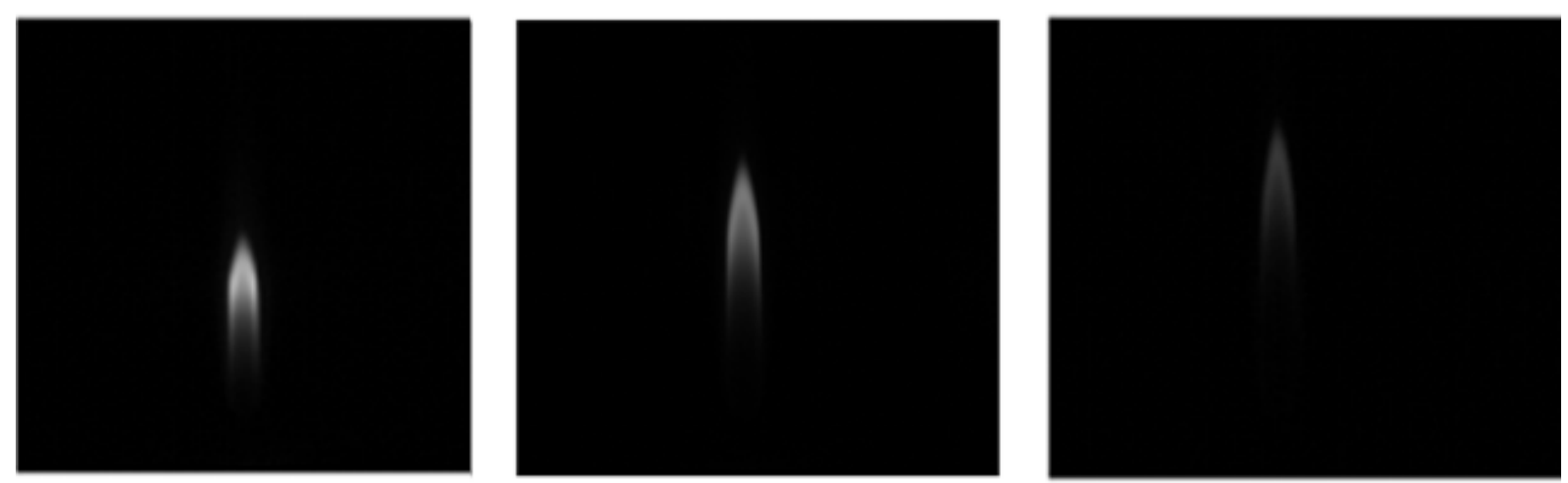

Figura 32 - Chamas de metano em atmosferas controladas com fração molar de oxigênio de $50 \%, 40 \%$ e $35 \%$ respectivamente

mente inerte como um gás nobre permitiria obter chamas semelhantes a do ar. Consequentemente, o experimento foi refeito, porém utilizando argônio como o diluente. $\mathrm{O}$ objetivo é construir uma chama semelhante em tamanho e formato a chama no ar. Para as medições foi utilizado o filtro de $\mathrm{OH}^{\star}(300-310 \mathrm{~nm})$ acoplado ao intensificador de imagem. Nesse caso, a figura 33 a mostra a emissão luminosa de uma chama de difusão de metano em ar, enquanto a figura $33 \mathrm{~b}$ é a emissão de uma chama de metano em uma atmosfera de $80 \%$ argônio e $20 \%$ oxigênio por volume. A semelhança no formato e tamanho das duas indica que é possível replicar o comportamento macroscópico do ar com um diluente totalmente inerte. Isso difere do experimento anterior no qual a diluição com dióxido de carbono ocasionou diferença na morfologia da combustão em qualquer nível de diluição.

Continuando o estudo do efeito macroscópico do dióxido de carbono em chamas de difusão, foram feitos ensaios comparando o efeito do nitrogênio e do dióxido de carbono. Foi construída uma atmosfera de oxigênio puro utilizando queimador Yale com quartzo e no tubo central foi injetada uma mistura de metano diluído, primeiramente com dióxido de carbono e em seguida com nitrogênio. Devido as limitações experimentais: precisão e alcance operacional dos rotâmetros, a vazão de metano foi mantida constante, enquanto 


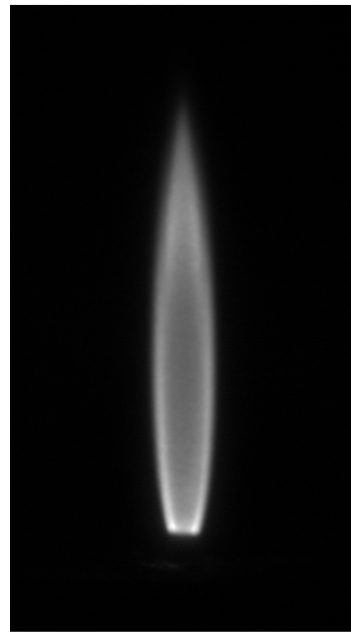

(a) Imagem de referência

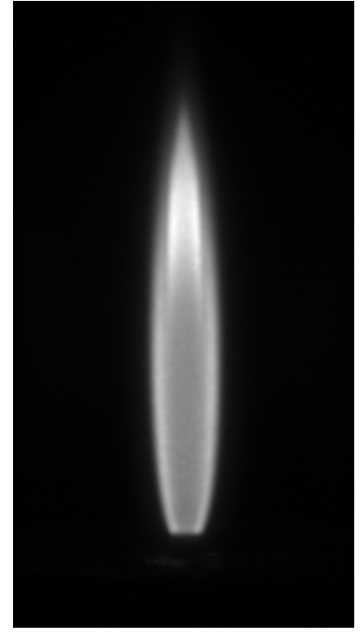

(b) Combustão em atmosfera de argônio

Figura 33 - Imagens de emissão de $\mathrm{OH}^{*}$

a vazão de gás diluente foi aumentada. Desse modo foi reduzida as incertezas no valor da vazão. A vazão no escoamento secundário foi de $50 \mathrm{l} / \mathrm{min}$ de oxigênio e a vazão de metano no tubo central foi de $0,67 \mathrm{l} / \mathrm{min}$. A tabela 5 mostra as vazões adicionais de diluentes utilizadas e a velocidade média prevista na saída do queimador, as incertezas para o valor da vazão adicional é $0,05 \mathrm{~L} / \mathrm{min}$. A última entrada na tabela é a máxima vazão que foi possível antes que a chama se extinguisse. Percebe-se que a chama ficou mais estável com a diluição de nitrogênio do que com a diluição de dióxido de carbono, suportando um volume $46,5 \%$ maior de gás diluente no ponto anterior a extinção.

Tabela 5 - Composições do escoamento no tubo central

\begin{tabular}{c|c|c|c} 
Vazão de $\mathrm{CO}_{2}(\mathrm{~L} / \mathrm{min})$ & Velocidade(m/s) & Vazão de $N 2(\mathrm{l} / \mathrm{min})$ & Velocidade(m/s) \\
\hline 0,41 & 1,45 & 1,02 & 2,28 \\
0,81 & 2,00 & 1,53 & 2,96 \\
1,22 & 2,55 & 2,03 & 3,65 \\
1,62 & 3,09 & 2,54 & 4,33 \\
2,03 & 3,64 & 3,05 & 5,02 \\
2,43 & 4,18 & 3,56 & 5,70
\end{tabular}

As figuras 32 e 34 mostram a luminescência total sem nenhum filtro ou intensificador de imagem captando todo o espectro visível. No teste subsequente foi calculada a fração molar de diluente no fluxo de gás que passa pelo tubo central, esse valor em porcentagem foi chamado de diluição. A figura 34a e 34c mostram os casos limites com as chamas com as maiores diluições alcançadas antes da extinção, enquanto a figura $34 \mathrm{~b}$ exibe uma chama com diluição próxima do caso limite do $\mathrm{CO}_{2}$. A chama diluída com nitrogênio não só se manteve estável, atingindo maiores concentrações de diluente, mas também possuiu um comprimento maior que o dobro da chama diluída com dióxido de car- 
bono. Esta diminuição do tamanho da chama é consistente com o caso anterior no qual o oxidante foi diluído ao invés do combustível. Como a quantidade de combustível é a mesma em todas as imagens na figura 34, a combustão com menor volume de reação deveria ser a mais intensa, já que a mesma quantidade de combustível é consumida em um espaço menor. Entretanto, se o caso com diluição de dióxido de carbono apresentasse as maiores taxas globais de reação, essa chama deveria ser mais estável. Além disso, seguindo esse raciocínio a chama diluída com dióxido de carbono deveria suportar diluições maiores e só se extinguir quando o seu volume for próximo ao da combustão diluída com nitrogênio. Essa diferença indica que a chama de dióxido de carbono não está produzindo a mesma quantidade de energia.

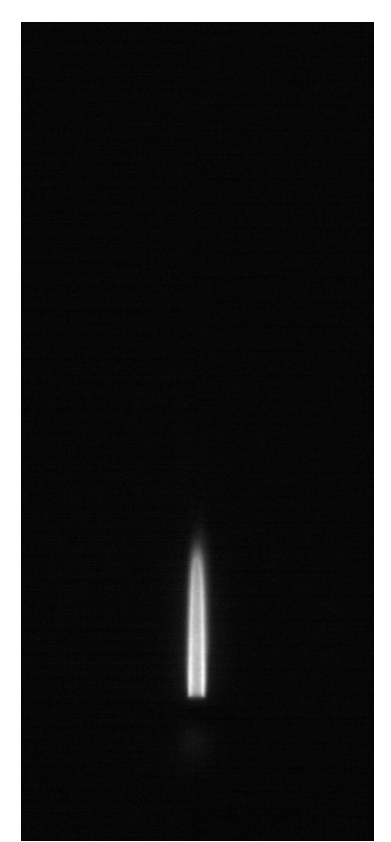

(a) Diluição de $78,37 \%$ de $\mathrm{CO}_{2}$

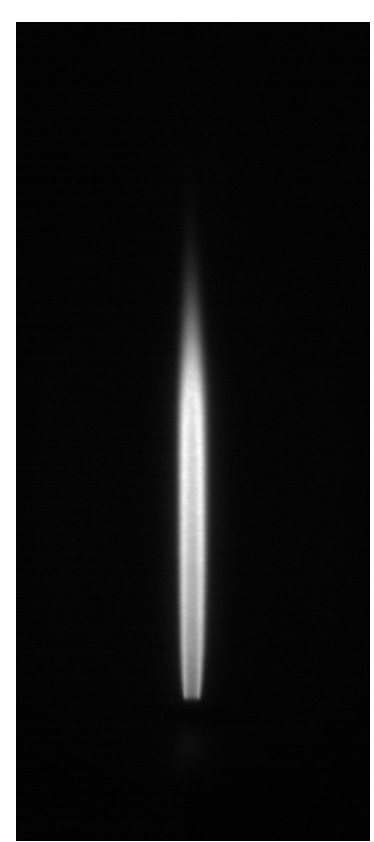

(b) Diluição de $79,10 \%$ de $N_{2}$

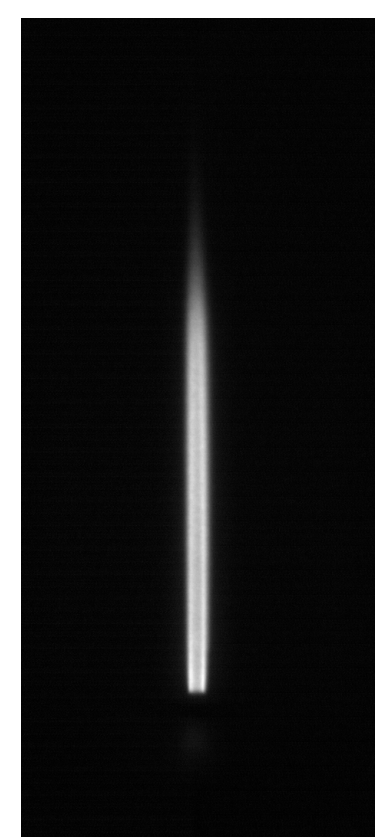

(c) Diluição de $84,12 \%$ de $N_{2}$

Figura 34 - Chamas de difusão com as maiores diluições obtidas

\subsection{Velocidade de chama laminar}

Prosseguindo o estudo, para aprofundar no fenômeno e avaliar se a maior capacidade térmica do $\mathrm{CO}_{2}$ poderia justificar satisfatoriamente as observações, um segundo queimador foi construído com o objetivo de medir a velocidade de chama laminar na oxicombustão. Porém, antes das medições na oxi-combustão, foram feitos testes com ar para verificar se poderiam ser obtidos resultados compatíveis com a literatura a fim de validar o queimador.

Para a combustão de metano em ar com a razão de equivalência unitária e temperatura inicial da pré-mistura em $300 \mathrm{~K}$, a velocidade de chama laminar é $40 \mathrm{~cm} / \mathrm{s}$ segundo Turns et al. (1996), a simulação com o GRI3.0 utilizando o software Chemkin19 calculou 
que a velocidade laminar é $38,2 \mathrm{~cm} / \mathrm{s}$. O gráfico 35 compara os valores da simulação com os dados coletados pela técnica de medição do ângulo do cone da chama laminar. Esse resultado monstra que o experimento é capaz de reproduzir os valores previstos pela literatura e portanto produzir resultados válidos em outras condições.

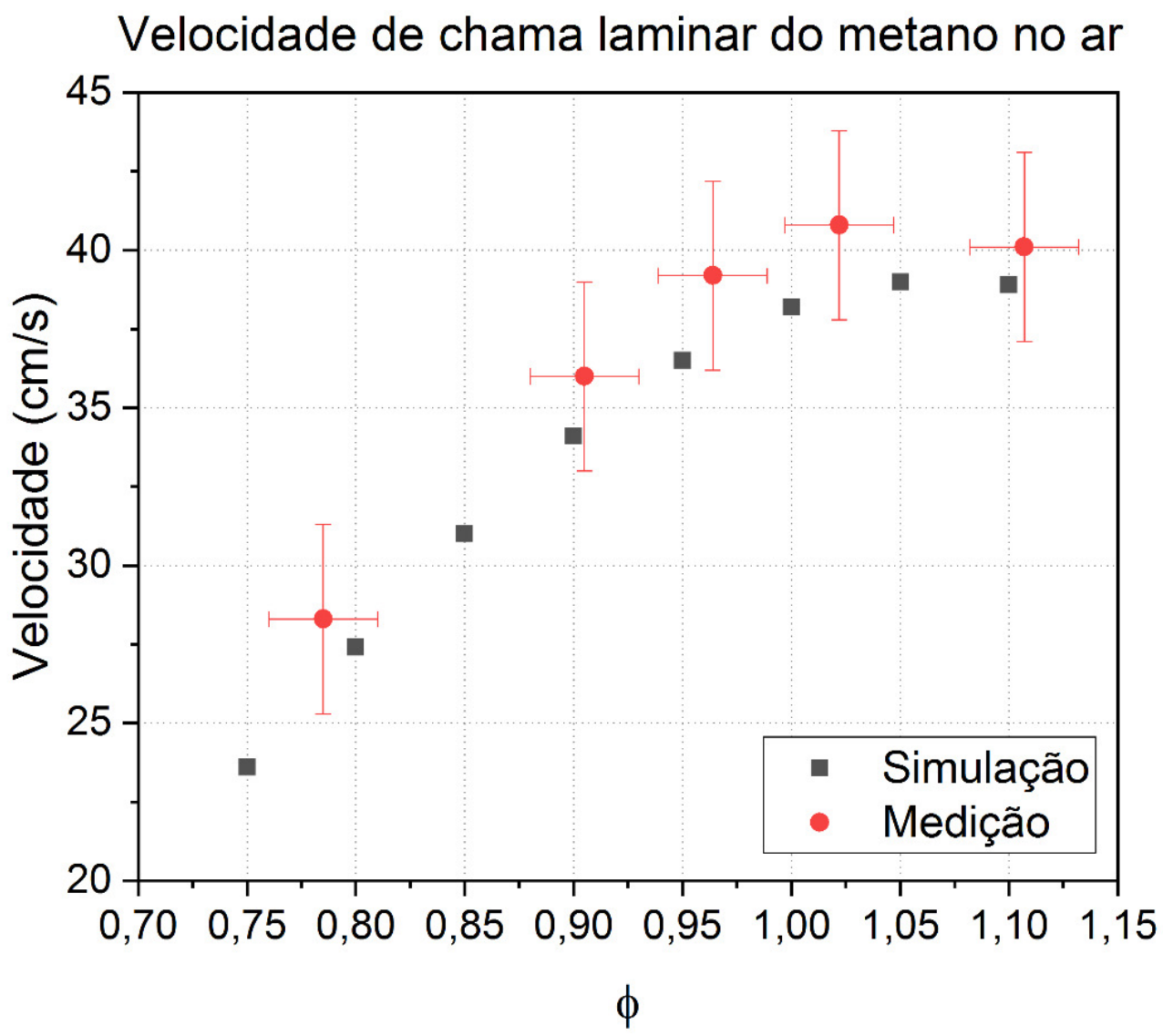

Figura 35 - Combustão de metano no ar

A grande dificuldade de se trabalhar com pré-misturas ricas em oxigênio, como ocorre na oxi-combustão, é o risco constante de explosões devido ao engolimento da chama. Por isso, para trabalhar com segurança, os experimentos de oxi-combustão foram feitos com a razão de equivalência 0,255 , esse grande excesso de oxidante reduz a velocidade laminar de chama para um patamar seguro de operação. Assim, foram realizados testes utilizando o dióxido de carbono, nitrogênio e o argônio como diluentes, objetivando avaliar as diferenças nas velocidades de chama laminar, comparar com os resultados numéricos e avaliar se misturas com capacidades térmica próximas apresentam a mesma velocidade. Cada experimento foi classificado de acordo com a fração molar de diluente na mistura chamada de diluição. A gráfico 36 mostra os pontos medidos com as incertezas estimadas e as velocidades previstas pela simulação numérica. Devido as limitações de vazão obtidas com os reguladores de gás não foi possível espaçar uniformemente os pontos medidos, além disso as incertezas nas medidas são elevadas. Ainda assim percebe-se 
uma diferença entre os gases diluentes superior as incertezas.

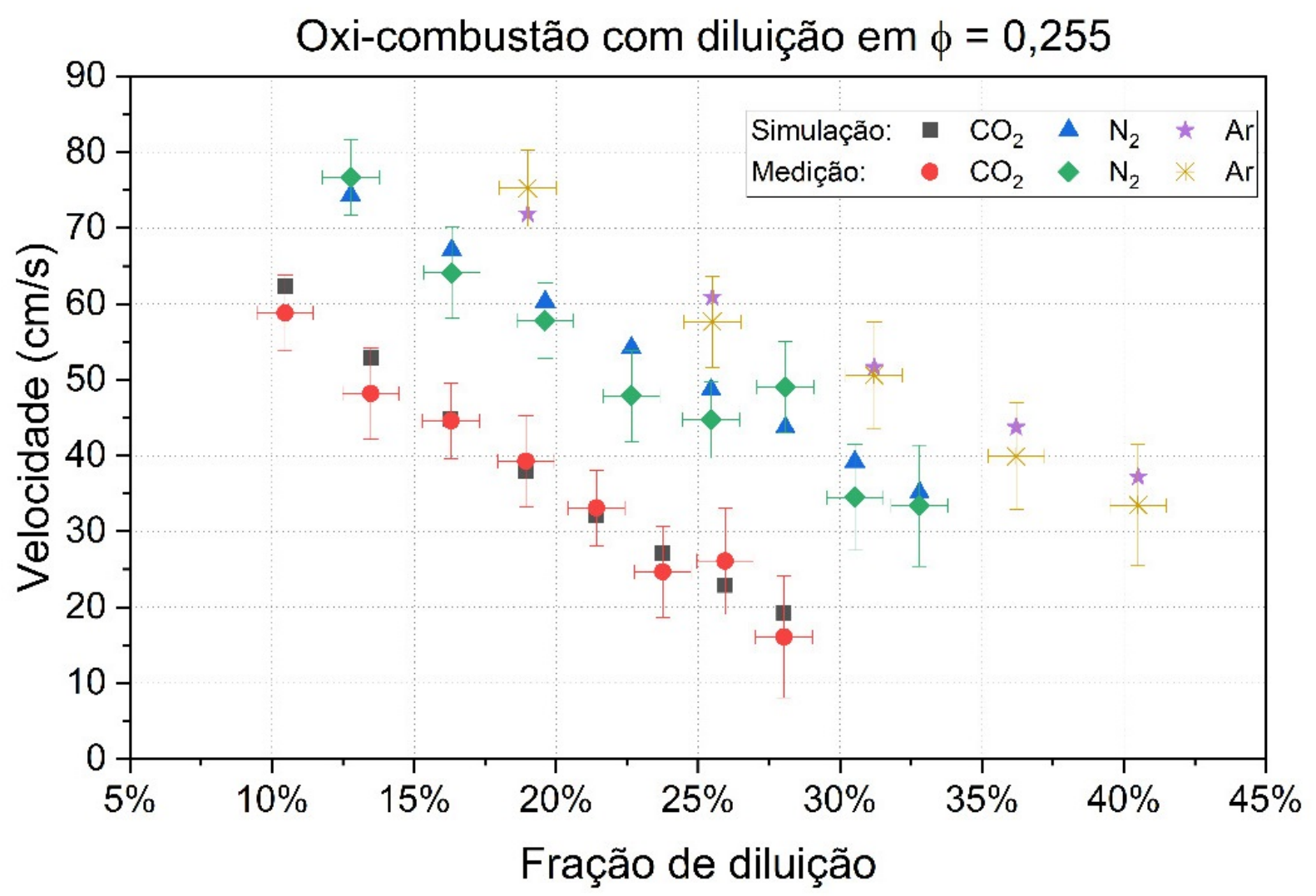

Figura 36 - Oxi-combustão diluída com $\mathrm{CO}_{2}, \mathrm{~N}_{2}$ e $\mathrm{Ar}$

Analisando os dados do gráfico 36 , nota-se que para uma diluição de cerca de $10,5 \%$ de $\mathrm{CO}_{2}$ tem-se a mesma velocidade de chama que uma diluição de aproximadamente $19,5 \%$ de $N_{2}$ e $25,5 \%$ de $A r$. Se essa diferença fosse devida a maior capacidade térmica do dióxido de carbono, a temperatura final dos produtos de combustão deveria ser aproximadamente o mesmo nos dois casos. Pode -se utilizar a temperatura adiabática de chama calculada com equilíbrio químico como comparativo, pois esse calculo não considera os efeitos químicos ou de transporte. Realizando esses cálculos, a temperatura do caso diluído com $19,5 \%$ de $N_{2}$ foi de $2119 \mathrm{~K}$, enquanto a oxi-combustão diluída com $10,5 \%$ de $\mathrm{CO}_{2}$ foi de $2264 \mathrm{~K}$. Dessa forma, mesmo podendo atingir temperaturas maiores, a chama laminar diluída com dióxido de carbono apresenta a mesma velocidade. Entretanto, essa análise não significa que as duas chamas reais não possam ter a mesma temperatura final, pois no cálculo anterior os efeitos de transporte são desprezados. Ainda assim, a justificativa da maior capacidade térmica do dióxido de carbono é inconsistente com essa observação. Analisando outros pares (tabela 6) de pontos com a mesma velocidade de chama essa tendência se mantém com as temperaturas da diluição com $\mathrm{CO}_{2}$ sendo sempre maiores.

Como resultado secundário o experimento vai de encontro com a literatura e con- 
Tabela 6 - Temperaturas de chama adiabáticas para diluições com velocidade de chama laminar próximas

\begin{tabular}{c|c|c|c} 
Diluição $\mathrm{CO}_{2} / \mathrm{N} 2 / \mathrm{Ar}$ & Temperatura com $\mathrm{CO}_{2}$ & Temperatura com $N_{2}$ & Temperatura com $\mathrm{Ar}$ \\
\hline $10,5 \% / 19,5 \% / 25,5 \%$ & $2264 \mathrm{~K}$ & $2119 \mathrm{~K}$ & $2146 \mathrm{~K}$ \\
$13,5 \% / 22,8 \% / 31,2 \%$ & $2218 \mathrm{~K}$ & $2045 \mathrm{~K}$ & $2099 \mathrm{~K}$ \\
$21,3 \% / 30,5 \% / 41,5 \%$ & $2089 \mathrm{~K}$ & $1921 \mathrm{~K}$ & $1956 \mathrm{~K}$
\end{tabular}

firma que o modelo cinético GRI3.0 é capaz de realizar previsões precisas para a oxicombustão na presença de dióxide de carbono. O trabalho de Mazas et al. (2011) avaliou a precisão desse mecanismo em condições de razão de equivalência unitária com dados experimentais com pequenas incertezas, a conclusão foi que o modelo prevê satisfatoriamente a velocidade de chama laminar. Dessa forma, o mecanismo foi utilizado para avaliar condições muito perigosas para serem testadas nas atuais instalações laboratoriais ou que não podem ser atingidas no queimador construído, pois as altas velocidades necessárias para estabilizar a chama tornariam a combustão turbulenta.

Foram feitas simulações para a condição de $\phi=1$ e utilizando argônio, nitrogênio e dióxido de carbono como diluentes. Nessas simulações o argônio foi utilizado, pois é um gás nobre, portanto completamente inerte, e possui uma capacidade térmica constante com a temperatura e inferior a do nitrogênio. Assim, é um diluente que só deveria interferir devido a sua diferença de $C_{p}$.

O gráfico 37 mostra os dados obtidos com a simulação e três polinômios do segundo grau usados para ajustar os pontos coletados. O nitrogênio e o argônio possuem um comportamento quase linear com uma pequena concavidade negativa, outra observação é que a diferença de velocidades existente entre esses diluentes é menor e mais uniforme em relação ao dióxido de carbono. Este por sua vez apresenta uma diferença acentuada formando uma curva de concavidade positiva, isso significa que a velocidade é mais sensível inicialmente a mudanças na diluição. Este forte comportamento não-linear do dióxido de carbono que segue uma tendência diferente dos outros dois gases indica que há outros fenômenos afetando a velocidade de chama no caso do $\mathrm{CO}_{2}$ que não estão presentes nos outros gases. Comparando com o argônio, o dióxido de carbono é um produto da combustão, portanto ele pode alterar a cinética química enquanto o argônio afetaria principalmente a difusão e a capacidade térmica da mistura. Assim, essas diferenças não apontam para a maior capacidade térmica do dióxido de carbono como a principal causa da maior instabilidade na oxi-combustão utilizando $\mathrm{CO}_{2}$ como diluente.

\subsection{Queimador Cabra}

Para observar o efeito dessas mudanças em chamas turbulentas foi utilizado o terceiro queimador baseado no trabalho de Cabra et al. (2000), denominado queimador Ca- 


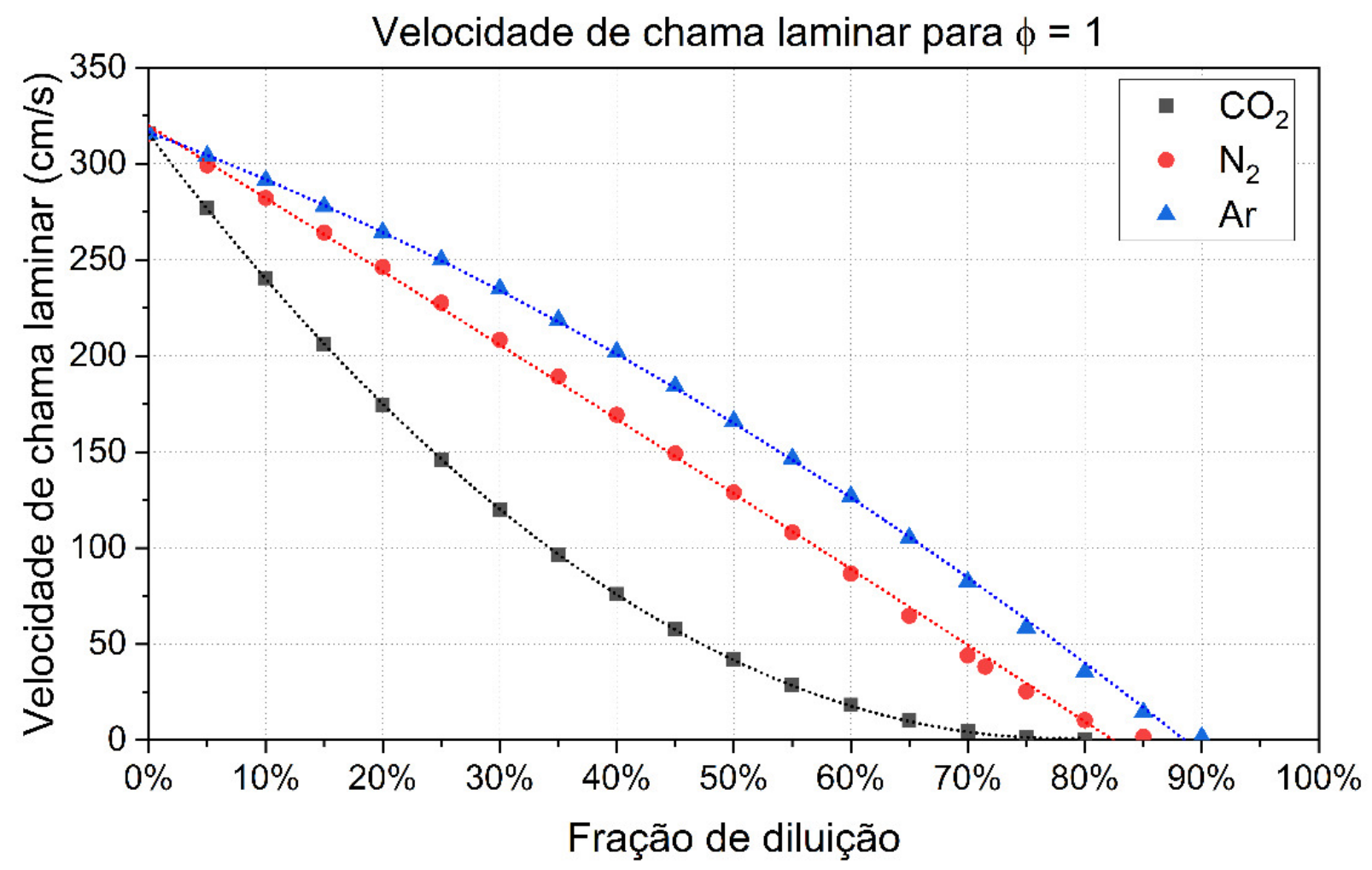

Figura 37 - Simulação com o mecanismo GRI3.0 de oxi-combustão com diferentes diluentes

bra. O primeiro teste foi tentar validar o queimador reproduzindo o experimento original. Nele a altura de uma chama suspensa (lifted) pré-misturada de ar e metano foi medida, essa estava em um escoamento secundário quente produzido por chamas piloto de hidrogênio. Entretanto, as instalações do laboratório não permitem operar com hidrogênio. Por isso, apesar das vazões no queimador central seguirem à do trabalho original, o escoamento secundário utilizou metano com a mesma razão de equivalência das chamas com hidrogênio. A tabela 7 resume os parâmetros utilizados nesse teste, porém ao analisar a imagem de quimioluminescência de $\mathrm{OH}^{*}$ (figura 38) obtidas percebe-se que a chama está ancorada. Essa diferença pode ter ocorrido por ser utilizado metano no luar de hidrogênio no escoamento secundário, ou devido a falta de um sistema de arrefecimento do queimador por água. Esse não foi adicionado ao queimador pois as instalações laboratoriais não permitem utilizar água com segurança, já que o ponto de água está muito distante $\mathrm{e}$ fora da zona protegida para a realização dos experimentos. Dessa forma, seria necessário operar o sistema com as portas do laboratório abertas e passar longas manguearias muito próximas a equipamentos eletrônicos sensíveis como câmeras de alta velocidade e lasers. Contudo, no trabalho original não existem dados a respeito da vazão utilizada no escoamento secundário, foi apenas medido a temperatura na placa perfurada.

Como não foi possível validar esse queimador, optou-se por trabalhar com o escoamento secundário apenas com ar e construir chamas suspensas, adicionando ar ou uma 
Tabela 7 - Parâmetros experimentais utilizados

\begin{tabular}{|c|c|}
\hline Vazão de ar no tubo central & $30 \mathrm{~L} / \mathrm{min} \pm 5 \mathrm{~L} / \mathrm{min}$ \\
\hline Vazão de metano no tubo Central & $60 \mathrm{~L} / \mathrm{min} \pm 5 \mathrm{~L} / \mathrm{min}$ \\
\hline Vazão de ar no escoamento secundário & $500 \mathrm{~L} / \mathrm{min} \pm 20 \mathrm{~L} / \mathrm{min}$ \\
\hline phi do escoamento secundário & $0,4 \pm 0,05$ \\
\hline
\end{tabular}

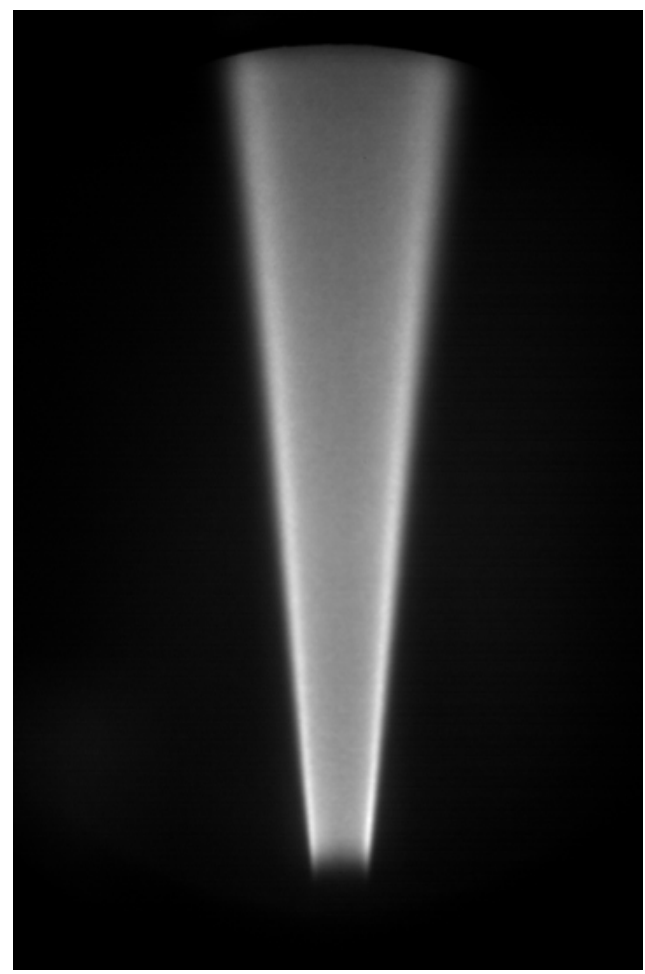

Figura 38 - Teste em escoamento secundário quente

mistura de $\mathrm{CO}_{2}$ e $\mathrm{O}_{2}$ no tubo central. Permitindo, assim, comparar chamas turbulentas suspensa com e sem a presença do dióxido de carbono, é esperado que o $\mathrm{CO}_{2}$ diminua as taxas globais de reação desancorando a chama em velocidades menores e com alturas maiores.

Para medir a altura das chamas foi utilizada a técnica da quimioluminescência de $\mathrm{OH}^{*}$ com imagem calibrada. Para a calibração foi utilizado um alvo com pontos de $0,5 \mathrm{~mm}$ de diâmetro com distancia entre centros de $3 \mathrm{~mm}$. No primeiro ensaio foi criada uma chama suspensa em um escoamento secundário de $100 \mathrm{~L} / \mathrm{min}$ de ar com um escoamento no jato principal de 13,4 L/min de metano e $4 \mathrm{~L} / \mathrm{min}$ de ar. Os resultados são mostrados na figura 39, essas imagens já foram corrigidas dos efeitos de distorção causados pelo conjunto óptico. Para melhorar a visualização da altura da chama a imagem de quimioluminescência (figura 39a foi sobreposta à imagem do calibrador (figura 39b). Nesse experimento a altura medida foi de $97 \mathrm{~mm}$.

Em seguida foram feitos ensaios, substituindo o ar por uma mistura de oxigênio e dióxido de carbono. Como a chama passou a descolar mais facilmente foi utilizada nesses 


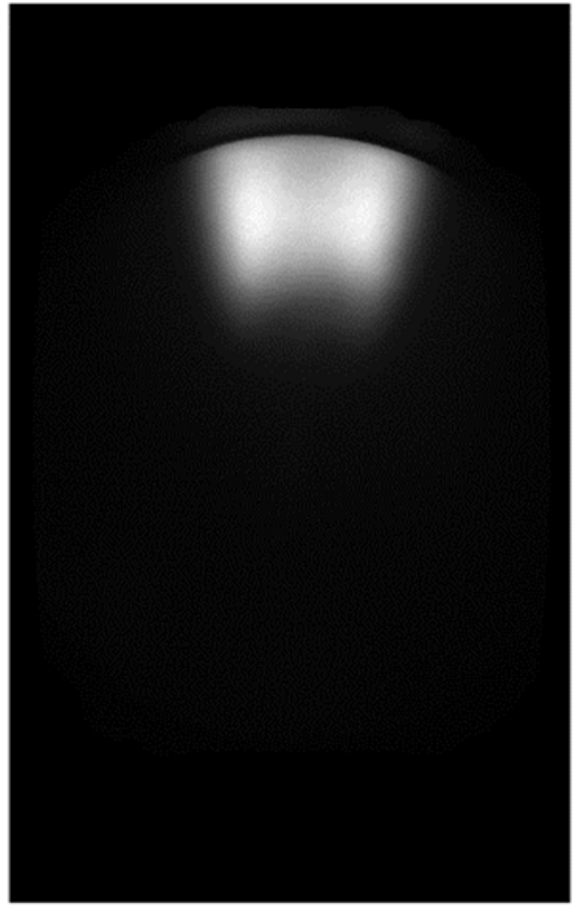

(a) Imagem de quimioluminescência de $\mathrm{OH}^{\star}$

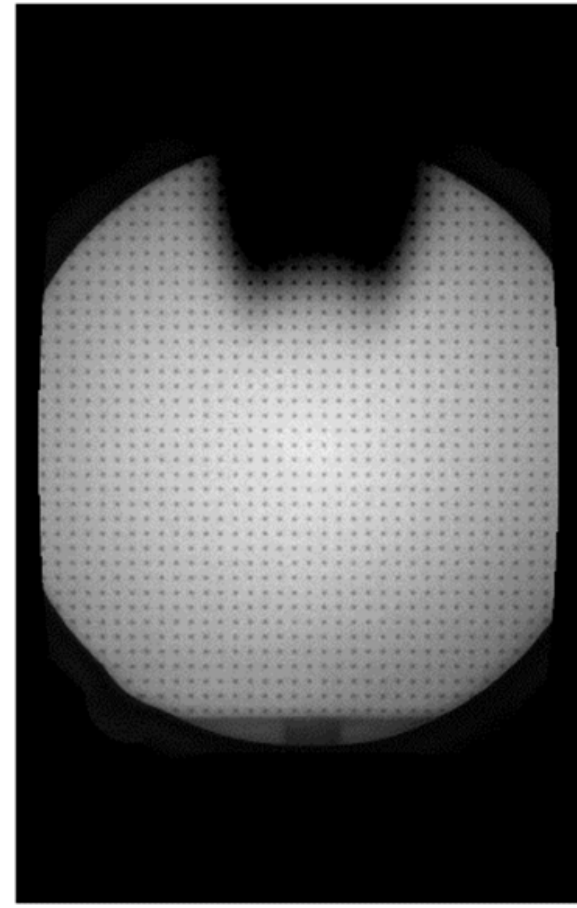

(b) Chama sobreposta sobre o calibrador

Figura 39 - Chama suspensa com ar e metano no tubo central

Tabela 8 - Alturas das chamas em função da diluição da mistura combustível com $\mathrm{CO}_{2}$

\begin{tabular}{c|c|c} 
Velocidade média(m/s) & Vazão de $\mathrm{CO}_{2}(\mathrm{~L} / \mathrm{min})$ & Altura da chama $(\mathrm{mm})$ \\
\hline 12,89 & 0,41 & 31 \\
13,30 & 0,81 & 46 \\
13,71 & 1,22 & 54 \\
14,13 & 1,63 & 73 \\
14,54 & 2,03 & 96
\end{tabular}

ensaios uma vazão menor de metano. Desse modo, em todos os testes foi utilizada a vazão de 11,42 L/min de metano, com incerteza de 0,5 L/min, e 0,86 L/min de oxigênio,com incerteza de $0,1 \mathrm{~L} / \mathrm{min}$, enquanto que a vazão de dióxido de carbono variou em cada caso, com incerteza de $0,05 \mathrm{~L} / \mathrm{min}$. A incerteza na altura foi de $3 \mathrm{~mm}$.Na figura $40 \mathrm{a}$ é mostrada a emissão do $\mathrm{OH}^{*}$ para a chama diluída com $0,41 \mathrm{~L} /$ min de dióxido de carbono, neste caso a altura da chama foi de $31 \mathrm{~mm}$, em seguida na figura $40 \mathrm{~b}$ a quimioluminescência é sobreposta à imagem do calibrador. A tabela 8, resume as vazões utilizadas de $\mathrm{CO}_{2}$ e a altura da chama obtida. Percebe-se que com o dióxido carbono a chama atinge uma altura maior do que o caso com o ar, apesar da menor vazão no tubo central. 


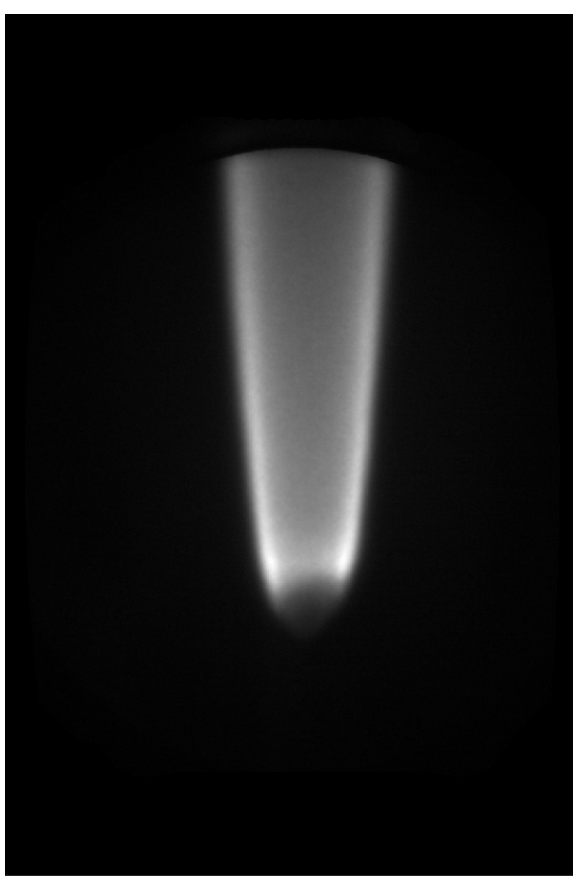

(a) Imagem de quimioluminescência de $\mathrm{OH}^{*}$

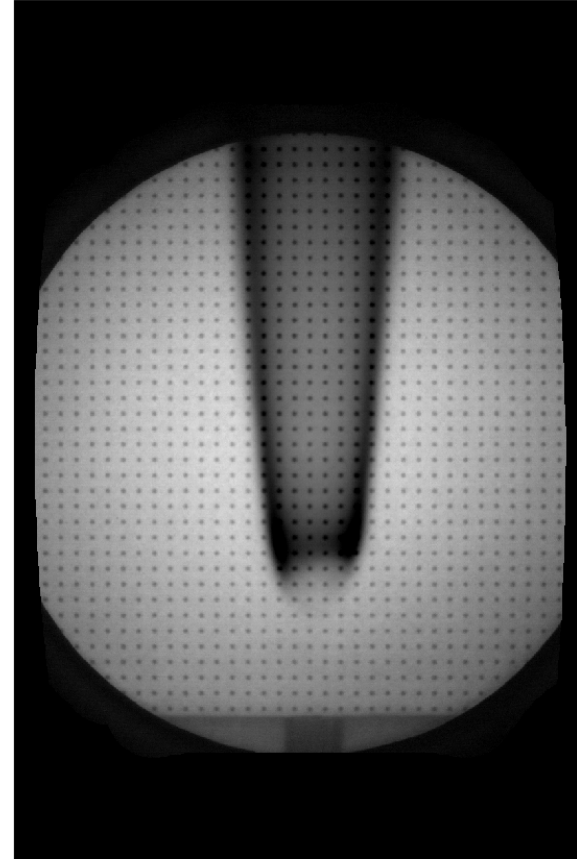

(b) Chama sobreposta sobre o calibrador

Figura 40 - Chama suspensa com dióxido de carbono, oxigênio e metano no tubo central, caso $0,41 \mathrm{~L} / \min C O 2$

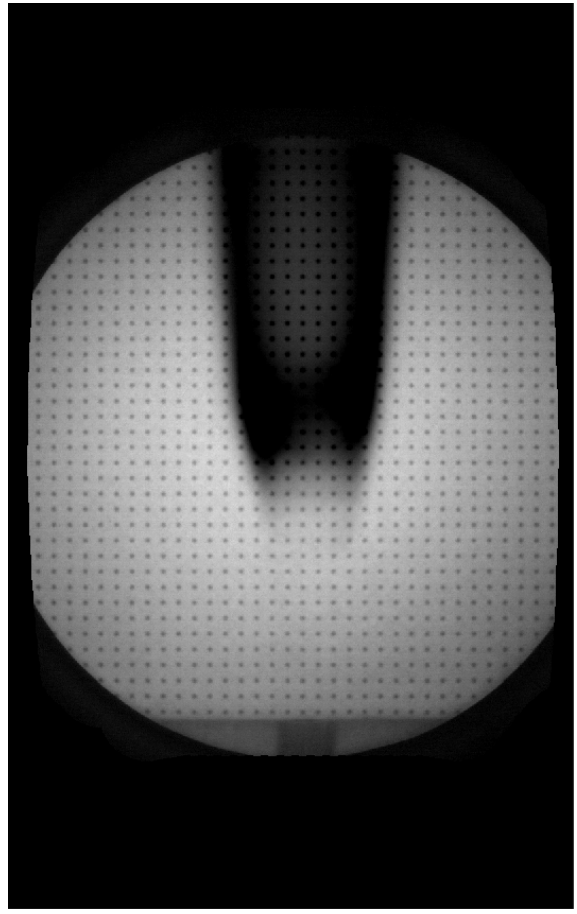

(a) $0,81 \mathrm{~L} / \mathrm{min}$ de $\mathrm{CO}_{2}$

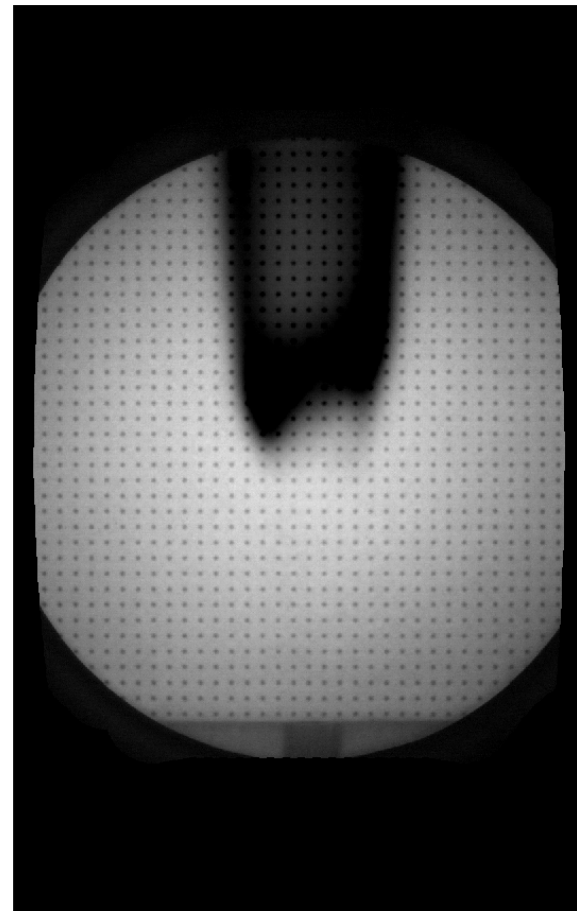

(b) $1,22 \mathrm{~L} / \mathrm{min}$ de $\mathrm{CO}_{2}$

Figura 41 - Ensaios com chama suspensa com quantidades crescentes de $\mathrm{CO}_{2}$, casos $0,81 \mathrm{~L} / \mathrm{min}$ e $1,22 \mathrm{~L} / \mathrm{min}$ de $\mathrm{CO}_{2}$ 


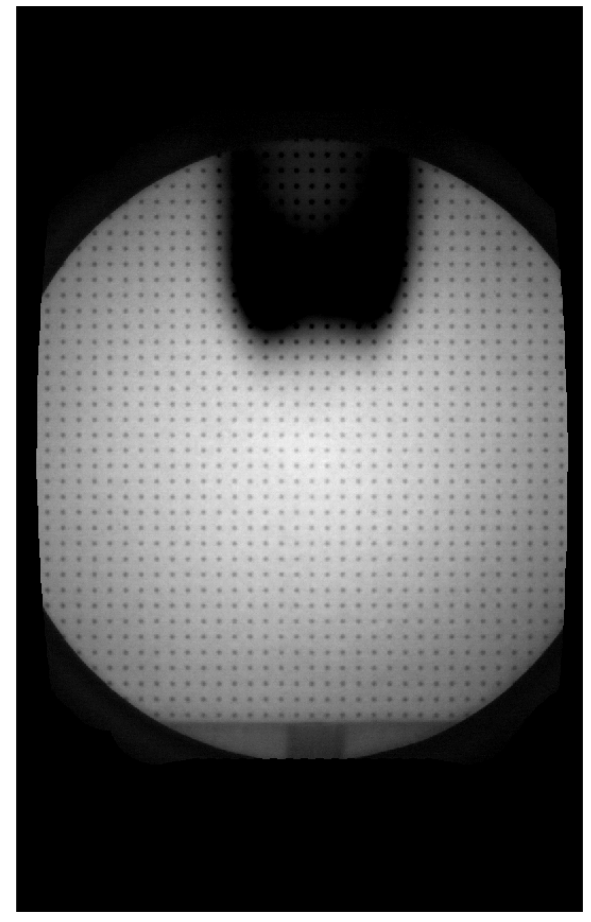

(a) 1,62 L/min de $\mathrm{CO}_{2}$

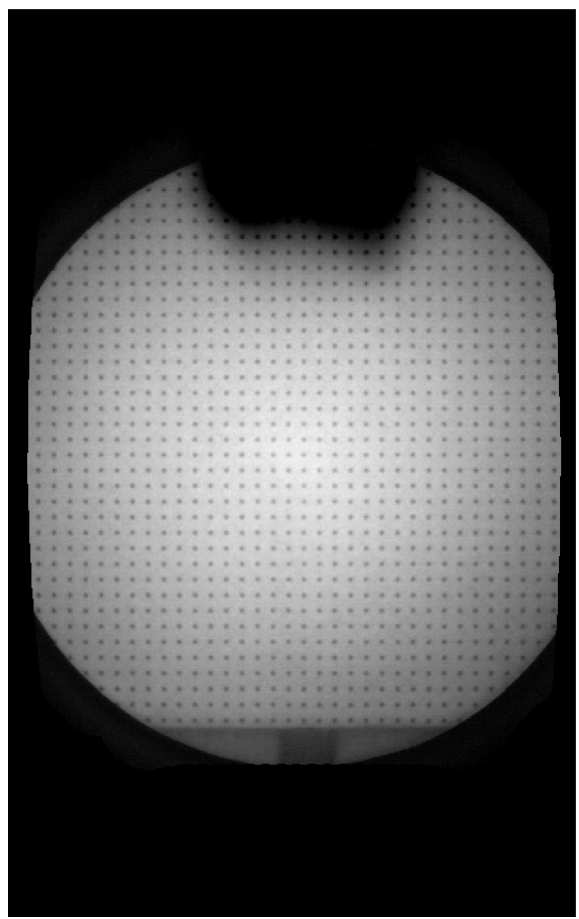

(b) 2,03 L/min de $\mathrm{CO}_{2}$

Figura 42 - Ensaios com chama suspensa com quantidades crescentes de $\mathrm{CO}_{2}$, casos $1,62 \mathrm{~L} / \mathrm{min}$ e $2,03 \mathrm{~L} / \mathrm{min}$ de $\mathrm{CO}_{2}$ 


\section{Conclusão}

Ao longo deste trabalho, os efeitos da adição de dióxido de carbono no processo de oxi-combustão foi avaliado. Em concordância com a literatura foi observada uma diminuição da estabilidade da combustão. Além disso, a análise qualitativa mostrou chamas menores e mais fracas quando o dióxido de carbono foi utilizado como diluente. Essa diferença é um desafio para a utilização da tecnologia de oxi-combustão, pois pode aumentar o consumo de oxigênio e combustível tornando essa abordagem inviável comercialmente. Outra dificuldade é que um comportamento muito diferente em relação a combustão convencional pode fazer que não seja possível reutilizar os queimadores existentes o que tira um atrativo importante dessa tecnologia. Idealmente, buscaria-se uma certa mistura de oxigênio e dióxido de carbono cujo comportamento aproximasse o do ar. Mas para atingir esse objetivo prático é necessário compreender as causas dessa mudança. Assim, este estudo focou em avaliar se a diferença de capacidade térmica do dióxido de carbono seria o principal responsável pelas alterações encontradas. Se fosse esse o caso, poderia ser viável buscar uma mistura análoga ao ar, já que o efeito da maior capacidade térmica do $\mathrm{CO}_{2}$ afetaria de forma mais previsível e mais linear. Dessa forma haveria alguma combinação de dióxido de carbono e oxigênio que produziria os mesmo tamanhos de chama, velocidade de chama laminar e temperatura por exemplo.

$\mathrm{Na}$ primeira sequência de testes qualitativos, foi visto que em uma chama de difusão, independentemente da mistura utilizada como oxidante a chama da oxi-combustão sempre foi visivelmente diferente. Nesses testes a combustão do metano só permaneceu estável com uma fração molar superior a 30\% de oxigênio. Além disso, as imagens da quimioluminescência mostram que em todos os casos testados a chama foi menor e menos luminosa na faixa 390-440 nm do espectro luminoso. Essas diferenças já aponta para mudanças fundamentais e não-lineares no processo de combustão que impediram a construção de uma oxi-combustão semelhante a combustão convencional.

Na mesma linha a diluição do metano com dióxido de carbono e nitrogênio em uma atmosfera de oxigênio puro reforça a diferença entre os dois diluentes. A diluição com $\mathrm{CO}_{2}$ manteve a chama estável até cerca de $78 \%$ de diluição mas na mesma condição a zona de reação do nitrogênio foi mais de duas vezes maior. Além disso, adicionando $N_{2}$ foram feitas reações estáveis até a diluição de cerce de $84 \%$. Isso, novamente aponta para um fenômeno complexo com os dois processos apresentando diferenças fundamentais que não podem ser compatibilizadas simplesmente pela alteração da composição dos escoamentos. Entretanto, nada disso descarta a possibilidade de que a capacidade térmica seja fundamental. Para continuar a investigação coletando dados que correlacionem uma sensibilidade maior que não possa ser explicada pelo $C_{p}$ do $\mathrm{CO}_{2}$ foi utilizado outro queimador 
para medir a velocidade de chama laminar de misturas de oxi-combustão.

Os ensaios experimentais avaliaram a velocidade de chama laminar para uma razão de equivalência baixa $(\phi=0,255)$ devido as limitações de velocidade que podiam ser usadas no equipamento. A técnica da chama cônica foi utilizada para calcular essa velocidade. Os resultados mostram uma diferença acima das incertezas para aproximadamente o mesmo valor de diluição, porém com gases diferentes (dióxido de carbono e nitrogênio). Além disso, comparando casos com velocidades próximas, percebeu-se que ao estimar a temperatura da combustão, utilizando um reator adiabático e equilíbrio químico, as chamas diluídas com $\mathrm{CO}_{2}$ sempre apresentam temperaturas superiores da ordem de $150 \mathrm{~K}$. Assim, se o efeito da capacidade térmica fosse determinante nesse calculo as temperaturas deveriam ser próximas dentro de cada par. Como resultado secundário o modelo GRI3.0 foi capaz de prever dentro da incerteza experimental os valores da velocidade de chama laminar.

Por fim, para avaliar casos impossíveis de serem testados atualmente no laboratório foi feita uma simulação numérica com três diluentes: argônio, nitrogênio e dióxido de carbono. Os resultados dessa simulação mostram uma marcante diferença de tendência entre o dióxido de carbono e os outros dois gases, indicando que nesse caso outros efeitos são mais predominantes do que com os outros gases inertes. Isso parece apontar claramente para a influência química do dióxido de carbono deslocando os potenciais químicos, pois apenas esse gás poderia afetar a combustão dessa maneira. Outra observação interessante é que para atingir a mesma velocidade de chama laminar do ar seria necessário uma diluição de cerca de $51 \%$. Mas nesse caso a temperatura adiabática(2381K) também será maior do que a do $\operatorname{ar}(2224 \mathrm{~K})$. Além disso, se baseado na estequiometria dessa chama fosse construída uma chama de difusão de metano que tivesse na zona de reação uma composição semelhante a do caso pré-misturado o oxidante seria composto por cerca de $40 \% \mathrm{O}_{2}$ e $60 \% \mathrm{CO}_{2}$. Entretanto, como os primeiros experimentos mostraram esse caso não se assemelha à combustão convencional. Isso exemplifica que apesar de ser possível obter proporções de oxigênio e dióxido de carbono que emulem uma determinada propriedade da combustão convencional(temperatura, velocidade de chama laminar) o comportamento global será diferente. Assim, indicando uma causa não-linear que afeta diferentemente as propriedades e os fenômenos observado na oxi-combustão, algo incompatível com a hipótese da capacidade térmica.

Como um estudo de caso do impacto do dióxido de carbono em chamas turbulentas foi medido a altura de chamas suspensas utilizando ar e uma mistura de oxigênio e dióxido de carbono junto com o combustível. No teste com ar no tubo central foi necessário uma velocidade maior na saída do jato para que a chama se descolasse da ponta do tubo. Enquanto que o caso com dióxido de carbono foi mais sensível e se descolou mais facilmente. Além disso, um pequeno aumento da quantidade desse gás, aumentou a altura 
da chama apesar da sua baixa concentração.

\subsection{Trabalhos Futuros}

Para continuar a compreender as causas das mudanças observadas na oxi-combustão trabalhos futuros podem abordar:

- Utilizar técnicas de medida óptica como PIV e PLIF para estudar o campo de velocidades e a distribuição espacial de radicais em chamas turbulentas

- Utilizar outro diluente como o vapor d’água.

- Melhorar a precisão experimental nas medidas de velocidade de chama laminar

- Estudar o efeito da pressão sobre a oxi-combustão

- Realizar experimentos com múltiplas entradas de oxidante com composições diferentes.

- Desenvolvimento um modelo de combustão que aceite múltiplas entradas de oxidante e combustível com composições diferentes. 



\section{Publicações}

Durante os trabalhos no Centro de Pesquisa em Combustão do Laboratório de Engenharia Térmica e Ambiental foram feitas as seguintes publicações:

- Experimental Study of Oxy-Fuel Combustion in a Coflow Burner - Encit 2018. Como primeiro autor.

- Turbulence characterization of a flow around a DI injector by means of TR-PIV - X Mediterranean Combustion Symposium. Como autor secundário. 



\section{Referências}

ALZUETA, Maria U; GLARBORG, Peter; DAM-JOHANSEN, Kim. Low temperature interactions between hydrocarbons and nitric oxide: an experimental study. Combustion and flame, Elsevier, v. 109, n. 1, p. 25-36, 1997.

ANDERSON, Roger E; MACADAM, Scott; VITERI, Fermin; DAVIES, Daniel O; DOWNS, James P; PALISZEWSKI, Andrew. Adapting gas turbines to zero emission oxy-fuel power plants. In: AMERICAN SOCIETY OF MECHANICAL ENGINEERS. ASME Turbo Expo 2008: Power for Land, Sea, and Air. [S.I.], 2008. p. 781-791.

AZZONI, Riccardo; RATTI, Stefano; AGGARWAL, Suresh K; PURI, Ishwar K. The structure of triple flames stabilized on a slot burner. Combustion and Flame, Elsevier, v. 119, n. 1, p. 23-40, 1999.

BALLARD, Dana H. Generalizing the hough transform to detect arbitrary shapes. Pattern recognition, Elsevier, v. 13, n. 2, p. 111-122, 1981.

BARLOW, RS; KARPETIS, AN; FRANK, JH; CHEN, J-Y. Scalar profiles and no formation in laminar opposed-flow partially premixed methane/air flames. Combustion and flame, Elsevier, v. 127, n. 3, p. 2102-2118, 2001.

BIROL, F. Key world energy statistics. [S.I.]: IEA Publications, International Energy Agency, rue de la Federation, Paris, France, 2017.

BODEN, TA; MARLAND, G; ANDRES, RJ. Global, Regional, and National Fossil-Fuel CO2 Emissions, Carbon Dioxide Information Analysis Center, Oak Ridge National Laboratory, Oak Ridge, Tennessee, USA. 2017.

BURNHAM, Andrew; HAN, Jeongwoo; CLARK, Corrie E; WANG, Michael; DUNN, Jennifer B; PALOU-RIVERA, Ignasi. Life-cycle greenhouse gas emissions of shale gas, natural gas, coal, and petroleum. Environmental science \& technology, ACS Publications, v. 46, n. 2, p. 619-627, 2011.

CABRA, R; CHEN, JY; DIBBLE, RW; HAMANO, Y; KARPETIS, AN; BARLOW, RS. Simultaneous raman-rayleigh-lif measurements and numerical modeling results of a lifted h2/n2 turbulent jet flame in a vitiated coflow. 2002.

CABRA, R; CHEN, J-Y; DIBBLE, RW; KARPETIS, AN; BARLOW, RS. Lifted methane-air jet flames in a vitiated coflow. Combustion and Flame, Elsevier, v. 143, n. 4, p. 491506, 2005.

CABRA, R; HAMANO, Y; CHEN, JY; DIBBLE, RW; ACOSTA, F; HOLVE, D. Ensemble diffraction measurements of spray combustion in a novel vitiated coflow turbulent jet flame burner. 2000.

CHEN, Lei; YONG, Sze Zheng; GHONIEM, Ahmed F. Oxy-fuel combustion of pulverized coal: Characterization, fundamentals, stabilization and cfd modeling. Progress in energy and combustion science, Elsevier, v. 38, n. 2, p. 156-214, 2012. 
CHEN, M; HERRMANN, Marcus; PETERS, N. Flamelet modeling of lifted turbulent methane/air and propane/air jet diffusion flames. Proceedings of the Combustion Institute, Elsevier, v. 28, n. 1, p. 167-174, 2000.

EICKHOFF, H; LENZE, B; LEUCKEL, W. Experimental investigation on the stabilization mechanism of jet diffusion flames. In: ELSEVIER. Symposium (International) on Combustion. [S.I.], 1985. v. 20, n. 1, p. 311-318.

GAYDON, Alferd. The spectroscopy of flames. [S.I.]: Springer Science \& Business Media, 2012.

GIMÉNEZ-LÓPEZ, Jorge; MILLERA, Angela; BILBAO, Rafael; ALZUETA, María U. Experimental and kinetic modeling study of the oxy-fuel oxidation of natural gas, ch 4 and $\mathrm{c} 2$ h 6. Fuel, Elsevier, v. 160, p. 404-412, 2015.

GLARBORG, Peter; BENTZEN, Line LB. Chemical effects of a high co2 concentration in oxy-fuel combustion of methane. Energy \& Fuels, ACS Publications, v. 22, n. 1, p. 291-296, 2007.

GLASSMAN, Irvin; YETTER, Richard A; GLUMAC, Nick G. Combustion. [S.I.]: Academic press, 2014.

GONZALEZ, Rafael C; WOODS, Richard C. Processamento digital de imagens . [S.I.]: Pearson Educación, 2009.

GUIBERTI, TF; DUROX, D; SCHULLER, T. Flame chemiluminescence from co 2-and n 2diluted laminar ch 4/air premixed flames. Combustion and Flame, Elsevier, v. 181, p. 110-122, 2017.

HARDALUPAS, YI; ORAIN, M. Local measurements of the time-dependent heat release rate and equivalence ratio using chemiluminescent emission from a flame. Combustion and Flame, Elsevier, v. 139, n. 3, p. 188-207, 2004.

HASEGAWA, Takeharu. Development of semiclosed cycle gas turbine for oxy-fuel igcc power generation with co 2 capture. Progress in gas turbine performance, InTech, Rijeka, p. 25-50, 2013.

HEKKERT, Marko P; HENDRIKS, Franka HJF; FAAIJ, Andre PC; NEELIS, Maarten L. Natural gas as an alternative to crude oil in automotive fuel chains well-to-wheel analysis and transition strategy development. Energy policy, Elsevier, v. 33, n. 5, p. 579-594, 2005.

JIA, Lufei; TAN, Yewen; WANG, Chunbo; ANTHONY, EJ. Experimental study of oxy-fuel combustion and sulfur capture in a mini-cfbc. Energy \& Fuels, ACS Publications, v. 21, n. 6, p. 3160-3164, 2007.

KAUFMANN, Morgan. Machine vision: Theory, algorithms, practicalities. San Francisco, 2004.

KONTOROVICH, AE; EPOV, MI; EDER, LV. Long-term and medium-term scenarios and factors in world energy perspectives for the 21 st century. Russian Geology and Geophysics, Elsevier, v. 55, n. 5-6, p. 534-543, 2014. 
KVAMSDAL, Hanne M; JORDAL, Kristin; BOLLAND, Olav. A quantitative comparison of gas turbine cycles with co2 capture. Energy, Elsevier, v. 32, n. 1, p. 10-24, 2007.

LEO, Maurizio De; SAVELIEV, Alexei; KENNEDY, Lawrence A; ZELEPOUGA, Serguei A. Oh and ch luminescence in opposed flow methane oxy-flames. Combustion and Flame, Elsevier, v. 149, n. 4, p. 435-447, 2007.

LEUNG, Dennis YC; CARAMANNA, Giorgio; MAROTO-VALER, M Mercedes. An overview of current status of carbon dioxide capture and storage technologies. Renewable and Sustainable Energy Reviews, Elsevier, v. 39, p. 426-443, 2014.

LIU, Fengshan; GUO, Hongsheng; SMALLWOOD, Gregory J; GÜLDER, Ömer L. The chemical effects of carbon dioxide as an additive in an ethylene diffusion flame: implications for soot and no x formation. Combustion and Flame, Elsevier, v. 125, n. 1, p. 778-787, 2001.

MAAREN, A Van; THUNG, DS; GOEY, L R H DE. Measurement of flame temperature and adiabatic burning velocity of methane/air mixtures. Combustion Science and Technology, Taylor \& Francis, v. 96, n. 4-6, p. 327-344, 1994.

MASRI, AR; DIBBLE, RW; BARLOW, RS. The structure of turbulent nonpremixed flames revealed by raman-rayleigh-lif measurements. Progress in Energy and Combustion Science, Elsevier, v. 22, n. 4, p. 307-362, 1996.

MAZAS, AN; FIORINA, Benoit; LACOSTE, DA; SCHULLER, Thierry. Effects of water vapor addition on the laminar burning velocity of oxygen-enriched methane flames. Combustion and Flame, Elsevier, v. 158, n. 12, p. 2428-2440, 2011.

MENDIARA, Teresa; GLARBORG, Peter. Ammonia chemistry in oxy-fuel combustion of methane. Combustion and Flame, Elsevier, v. 156, n. 10, p. 1937-1949, 2009.

OTSU, Nobuyuki. A threshold selection method from gray-level histograms. IEEE transactions on systems, man, and cybernetics, IEEE, v. 9, n. 1, p. 62-66, 1979.

PANOUTSOS, CS; HARDALUPAS, Y; TAYLOR, AMKP. Numerical evaluation of equivalence ratio measurement using oh and ch chemiluminescence in premixed and non-premixed methane-air flames. Combustion and Flame, Elsevier, v. 156, n. 2, p. 273-291, 2009.

PLESSING, Tobias; TERHOEVEN, Peter; PETERS, Norbert; MANSOUR, Mohy S. An experimental and numerical study of a laminar triple flame. Combustion and Flame, Elsevier, v. 115, n. 3, p. 335-353, 1998.

POINSOT, Thierry; VEYNANTE, Denis. Theoretical and numerical combustion. [S.I.]: RT Edwards, Inc., 2005.

ROWINSKI, David H; POPE, Stephen B. Pdf calculations of piloted premixed jet flames. Combustion Theory and Modelling, Taylor \& Francis, v. 15, n. 2, p. 245-266, 2011.

SCHEFFKNECHT, Günter; AL-MAKHADMEH, Leema; SCHNELL, Uwe; MAIER, Jörg. Oxy-fuel coal combustion - a review of the current state-of-the-art. International Journal of Greenhouse Gas Control, Elsevier, v. 5, p. S16-S35, 2011. 
SMOOKE, MD; MCENALLY, CS; PFEFFERLE, LD; HALL, RJ; COLKET, MB. Computational and experimental study of soot formation in a coflow, laminar diffusion flame. Combustion and Flame, Elsevier, v. 117, n. 1, p. 117-139, 1999.

SUNDKVIST, Sven Gunnar; DAHLQUIST, Adrian; JANCZEWSKI, Jacek; SJÖDIN, Mats; BYSVEEN, Marie; DITARANTO, Mario; LANGØRGEN, Øyvind; SELJESKOG, Morten; SILJAN, Martin. Concept for a combustion system in oxyfuel gas turbine combined cycles. Journal of Engineering for Gas Turbines and Power, American Society of Mechanical Engineers, v. 136, n. 10, p. 101513, 2014.

TEAM, Core Writing; PACHAURI, Rajendra K; MEYER, LA. Ipcc, 2014: climate change 2014: synthesis report. contribution of working groups i. II and III to the Fifth Assessment Report of the intergovernmental panel on Climate Change. IPCC, Geneva, Switzerland, v. 151, 2014.

TURNS, Stephen R et al. An introduction to combustion. [S.I.]: McGraw-hill New York, 1996. v. 287.

VREMAN, AW; ALBRECHT, BA; OIJEN, JA Van; GOEY, LPH De; BASTIAANS, RJM. Premixed and nonpremixed generated manifolds in large-eddy simulation of sandia flame d and f. Combustion and Flame, Elsevier, v. 153, n. 3, p. 394-416, 2008.

WALL, Terry; STANGER, Rohan; SANTOS, Stanley. Demonstrations of coal-fired oxy-fuel technology for carbon capture and storage and issues with commercial deployment. International journal of greenhouse gas control, Elsevier, v. 5, p. S5-S15, 2011.

WOHL, Kurt; KAPP, Numer M; GAZLEY, Carl. The stability of open flames. In: ELSEVIER. Symposium on Combustion and Flame, and Explosion Phenomena. [S.I.], 1948. v. 3, n. 1, p. 3-21.

WOIKI, Dirk; VOTSMEIER, Martin; DAVIDSON, David F; HANSON, Ronald K; BOWMAN, Craig T. Ch-radical concentration measurements in fuel-rich ch 4/o 2/ar and ch 4/o 2/no/ar mixtures behind shock waves. Combustion and flame, Elsevier, v. 113, n. 4, p. 624-626, 1998.

ZHANG, Na; LIOR, Noam. Two novel oxy-fuel power cycles integrated with natural gas reforming and co 2 capture. Energy, Elsevier, v. 33, n. 2, p. 340-351, 2008. 